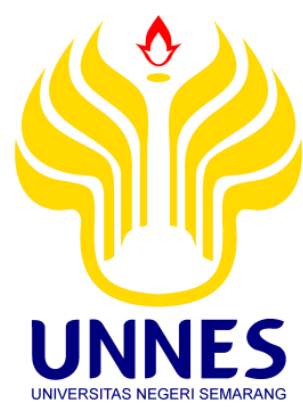

\title{
BENTUK PERTUNJUKAN KESENIAN SINTREN DANGDUT SEBAGAI UPAYA PELESTARIAN SENI TRADISI PADA GRUP PUTRA KELANA DI KELURAHAN PASARBATANG KABUPATEN BREBES
}

\author{
SKRIPSI \\ untuk memperoleh gelar Sarjana Pendidikan \\ oleh \\ Nama : Amalia Mega Hardiyanti \\ NIM : 2501412015 \\ Program Studi : Pendidikan Seni Tari \\ Jurusan $\quad$ : Pendidikan Seni Drama, Tari dan Musik
}

FAKULTAS BAHASA DAN SENI

UNIVERSITAS NEGERI SEMARANG

2016 


\section{PERSETUJUAN PEMBIMBING}

Skripsi ini telah disetujui oleh pembimbing untuk diajukan ke Sidang Panitia Ujian Skripsi.

Semarang, 28 Juli 2016

Pembimbing I,

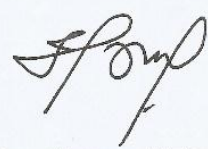

Drs. Bintang H. P., M. Hum NIP 196002081987021001
Pembimbing II,

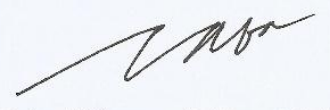

Joko Wiyoso, S. Kar., M. Hum NIP 196210041988031002 


\section{PENGESAHAN KELULUSAN}

Skripsi ini telah dipertahankan di hadapan sidang Panitia Ujian Skripsi Jurusan Pendidikan Seni Drama, Tari dan Musik, Fakultas Bahasa dan Seni, Universitas Negeri Semarang.

pada hari $\quad$ : Rabu

tanggal : 3 Agustus 2016

\section{Panitia Ujian Skripsi}

Prof. Dr. Agus Nuryatin, M.Hum (196008031989011001) Ketua

Drs. Suharto, S.Pd., M.Pd. (196510181990031002) Sekretaris

Dra. Eny Kusumastuti, M.Pd. (196804101993032001) Penguji I
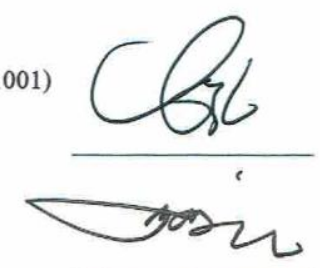

Joko Wiyoso, S.Kar., M.Hum. (196210041988031002) Penguji II/Pembimbing II
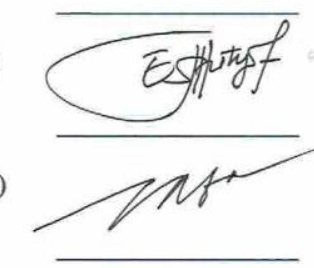

Drs. Bintang Hanggoro Putra, M.Hum. (196002081987021001) Penguji III/Pembimbing I
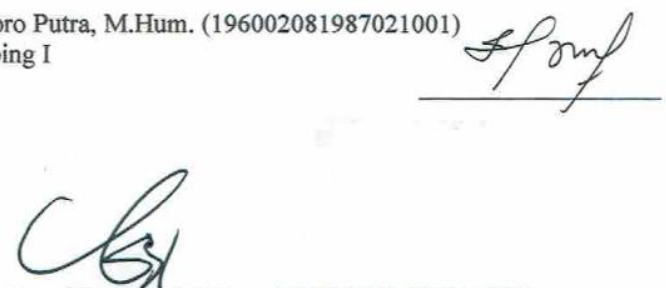

Prof. Dr. Agus Nuryatin, M.Hum. (196008031989011001)

Dekan Fakultas Bahasa dan Seni 


\section{PERNYATAAN}

Saya menyatakan bahwa yang tertulis di dalam skripsi ini benar-benar hasil karya saya sendiri, bukan jiplakan dari karya orang lain, sebagian atau seluruhnya. Pendapat atau temuan orang lain yang terdapat dalam skripsi ini dikutip atau dirujuk berdasarkan kode etik ilmiah.

Semarang, 28 Juli 2016

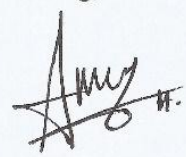

Amalia Mega Hardiyanti NIM 2501412015 


\section{MOTTO DAN PERSEMBAHAN}

Motto:

- Lupakan kesempurnaan dan bidiklah perbaikan, kamu akan menjadi apa yang kamu pikirkan (Andrew Matthews)

- Pendidikan merupakan senjata paling ampuh yang bisa kamu gunakan untuk merubah dunia (Nelson Mandela)

\section{Persembahan:}

- Universitas Negeri Semarang

- Fakultas Bahasa dan Seni

- Jurusan Pendidikan Seni Drama, Tari dan Musik (Seni Tari)

- Orang tua Alm. Bapak Abdul Haris dan Ibu Endang Supriyanti yang senantiasa memberikan dukungan, doa, dan motivasi.

- Nenekku tersayang yang senantiasa mendoakan.

- Adikku M. Ridho yang selalu memberi motivasi.

- Rista Weluri terimakasih atas doa, motivasi, dan semangatnya.

- Teman-teman seni tari 2012 "Bayi Wingi Sore". 


\section{KATA PENGANTAR}

Alhamdulillah Wasyukurillah, Puji syukur kehadirat Allah SWT, atas segala rahmat dan hidayah-Nya, sehingga peneliti dapat menyelesaikan skripsi dengan baik dan lancar.

Skripsi yang berjudul "Bentuk Pertunjukan Kesenian Sintren Dangdut Sebagai Upaya Pelestarian Seni Tradisi Pada Grup Putra Kelana Di Kelurahan Pasarbatang Kabupaten Brebes", disusun sebagai salah satu syarat untuk mencapai gelar Sarjana Pendidikan pada Jurusan Seni Drama, Tari dan Musik Fakultas Bahasa dan Seni Universitas Negeri Semarang.

Penyusunan skripsi ini peneliti memperoleh banyak bantuan dan bimbingan dari berbagai pihak. Pada kesempatan ini peneliti ingin mengucapkan terima kasih kepada:

1. Prof. Dr. Fathur Rokhman, M.Hum., Rektor Universitas Negeri Semarang yang telah memberi kesempatan peneliti untuk mengampu perkuliahan di Universitas Negeri Semarang dan penyusunan skripsi ini.

2. Prof. Dr. Agus Nuryatin, M.Hum., Dekan Fakultas Bahasa dan Seni Universitas Negeri Semarang yang telah memberi ijin dalam penyusunan skripsi ini.

3. Dr. Udi Utomo, M.Si., Ketua Jurusan Pendidikan Sendratasik Fakultas Bahasa dan Seni Universitas Negeri Semarang, yang telah memberikan ijin kepada penulis untuk menyusun skripsi.

4. Drs. Bintang Hanggoro Putra, M.Hum., selaku pembimbing I yang telah meluangkan waktu dengan sungguh-sungguh, sabar dan teliti dalam 
membimbing, mengoreksi serta memberikan semangat dan dorongan mental untuk menyelesaikan skripsi ini.

5. Joko Wiyoso, S. Kar., M.Hum., selaku pembimbing II yang telah meluangkan waktu, mengarahkan dengan sabar, serta memberikan semangat dan dorongan mental untuk menyelesaikan skripsi ini.

6. Bapak dan Ibu Dosen Prodi Pendidikan Seni Tari Jurusan Pendidikan Sendratasik Fakultas Bahasa dan Seni Universitas Negeri Semarang yang telah memberikan bekal ilmu dan pengetahuan kepada penulis sehingga penulis dapat menyelesaikan skripsi ini.

7. Bapak, Ibu, Nenek, adiku Ridho, serta segenap keluarga besar yang tak pernah lelah mendoakan, memberikan restu dan sabar memberikan dukungan selama penyusunan skripsi ini.

8. Bapak Dalang Wertadiharjo selaku Pimpinan grup Putra Kelana dan anggota Grup Putra Kelana yang telah memberikan ijin, kesempatan dan waktu untuk memberikan informasi selama pengambilan data.

9. Rista Weluri yang selalu menemani, memberikan dukungan, doa dan semangat dalam penyelesaian skripsi ini.

10. Semua teman-teman Pendidikan Sendratasik termasuk prodi Pendidikan Seni Tari angkatan 2012 (Bayi Wingi Sore) yang telah berbagi informasi dan memberikan semangat serta bantuan dalam penyelesaian skripsi ini.

11. Anak-anak Wisma Sekar Sari, Mangesthi, Wastem dan teman terbaikku Fitri, Idot, dan Rani Pramesthi yang selalu menyerukan kata-kata semangat. 
12. Semua pihak yang tidak dapat penulis sebutkan satu persatu yang telah membantu dalam penyelesaian skripsi ini.

Mudah-mudahan semua bantuan dan bimbingan yang telah diberikan kepada penulis dapat bermanfaat sebagai tambahan ilmu pengetahuan. Saran dan kritik yang membangun dari berbagai pihak sangat penulis harapkan untuk melengkapi skripsi ini. Penulis berharap semoga skripsi ini dapat bermanfaat dan berguna bagi semua pihak.

Semarang, 28 Juli 2016

Peneliti 


\section{SARI}

Hardiyanti, Amalia Mega. 2016. Bentuk Pertunjukan Kesenian Sintren Dangdut Sebagai Upaya Pelestarian Seni Tradisi Pada Grup Putra Kelana Di Kelurahan Pasarbatang Kabupaten Brebes. Skripsi. Prodi Pendidikan Seni Tari, Jurusan Pendidikan Sendratasik, Fakultas Bahasa dan Seni, Universitas Negeri Semarang. Pembimbing I: Drs. Bintang Hanggoro Putra, M. Hum, Pembimbing II: Joko Wiyoso, S. Kar., M. Hum.

Kata Kunci : Bentuk Pertunjukan, Sintren Dangdut, Upaya Pelestarian

Kesenian Sintren Dangdut memiliki keunikan tersendiri yaitu adanya musik dangdut dalam pertunjukan. Sintren yang dikenal oleh masyarakat sebagai kesenian yang religius dan sakral kini digabungkan dengan adanya musik dangdut. Musik dangdut dalam pertunjukan Sintren adalah sebagai selingan pertunjukan tetapi masih dalam satu pertunjukan sehingga menjadi Sintren Dangdut. Pokok permasalahan yang diajukan yaitu Bagaimana bentuk pertunjukan kesenian Sintren Dangdut sebagai upaya pelestarian seni tradisi pada Grup Putra Kelana di Kelurahan Pasarbatang Kabupaten Brebes. Tujuannya adalah mendeskripsikan bentuk pertunjukan kesenian Sintren Dangdut sebagai upaya pelestarian seni tradisi pada Grup Putra Kelana di Kelurahan Pasarbatang Kabupaten Brebes.

Penelitian ini menggunakan metode kualitatif yang bersifat deskriptif, dengan menggunakan pendekatan naturalistik dan fenomenologi. Teknik pengumpulan data yang digunakan yaitu: observasi, wawancara dan dokumentasi. Wujud data yang dikumpulkan dalam penelitian ini berupa data dan informasi yang berkaitan dengan Sintren Dangdut, kemudian data dan informasi tersebut dianalisis dengan menggunakan teori Miles \& Huberman yang membagi proses analisis menjadi empat komponen yaitu: Pengumpulan Data, Reduksi Data, Display Data, Penarikan Kesimpulan. Masing-masing berinteraksi membentuk satu siklus. Teknik pemeriksaan keabsahan data menggunakan triangulasi yaitu triangulasi sumber, triangulasi teknik, dan triangulasi waktu.

Hasil penelitian bentuk pertunjukan kesenian Sintren Dangdut yaitu adanya Lakon, Gerak, Pelaku, Iringan, Rias, Busana, Tata Pentas, Properti, Penonton, dan Urutan Pertunjukan. Pelaku pada pertunjukan Sintren Dangdut meliputi pemeran Sintren Dangdut, Pawang, Bodhor, Kemladang, Sinden, Pemusik, Penyanyi Dangdut, Pembawa Acara. Perlengkapan pertunjukan berupa Kurungan, Kain Penutup Kurungan, Layah/Anglo, Dupa, Arang, Sesaji, dan Doa. Urutan pertunjukan dibagi menjadi tiga bagian yaitu bagian awal, bagian pertunjukan, dan akhir pertunjukan. Musik dangdut masuk dalam pertengahan pertunjukan menjadi selingan dan di akhir pertunjukan sebagai penutup pertunjukan. Upaya Pelestarian Seni Tradisi Sintren Dangdut berupa perlindungan, pengembangan dan pemanfaatan. Bentuk pertunjukan kesenian Sintren Dangdut terdapat faktor-faktor yang menunjang termasuk faktor pendukung dan penghambat. Jadi bentuk pertunjukan kesenian tradisional Sintren Dangdut diharapkan bisa dikembangkan lagi dan memajukan kesenian tradisional terutama kesenian Sintren Dangdut yang ada di Kabupaten Brebes. 


\section{DAFTAR ISI}

Halaman

LEMBAR JUDUL …....................................................................... i

LEMBAR PERSETUJUAN PEMBIMBING ........................................... ii

PENGESAHAN KELULUSAN _.......................................................... iii

PERNYATAAN KEASLIAN …................................................. iv

MOTTO DAN PERSEMBAHAN ….................................................. v

KATA PENGANTAR .......................................................................... vi

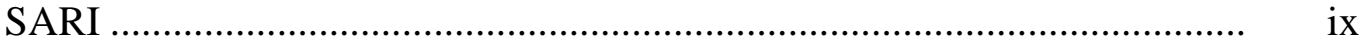

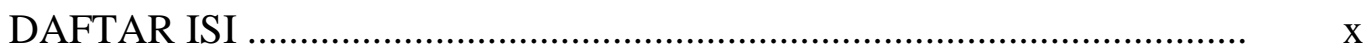

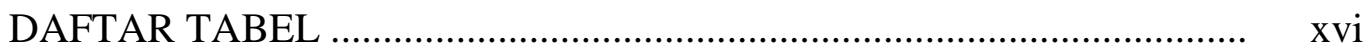

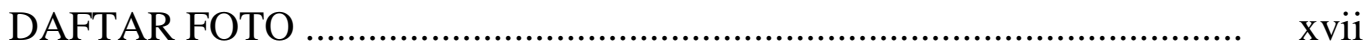

DAFTAR LAMPIRAN ….............................................................. xix

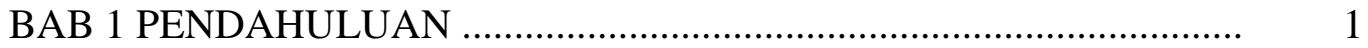

1.1 Latar Belakang Masalah .................................................................... 1

1.2 Rumusan Masalah .......................................................................

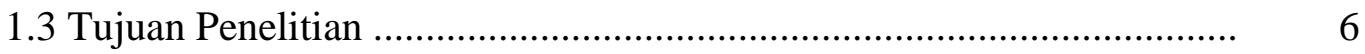

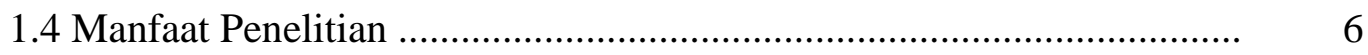

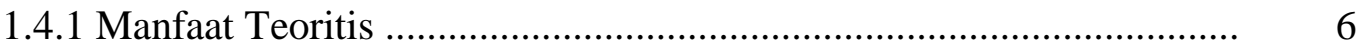

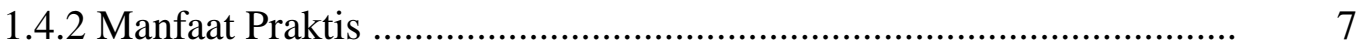

1.5 Sistematika Penulisan Skripsi ........................................................ 7 
2.1 Tinjauan Pustaka ................................................................... 10

2.2 Landasan Teoritis ................................................................. 16

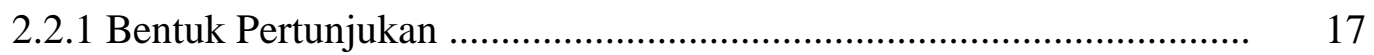

2.2.2 Unsur-Unsur Seni Pertunjukan .................................................... 18

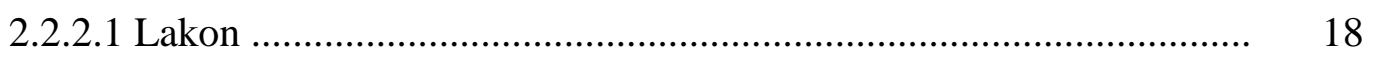

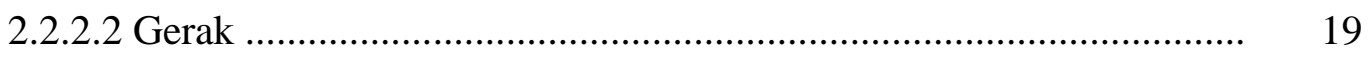

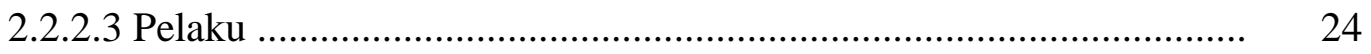

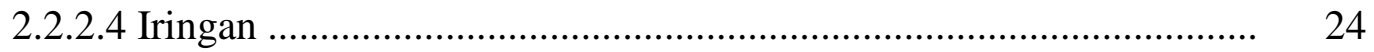

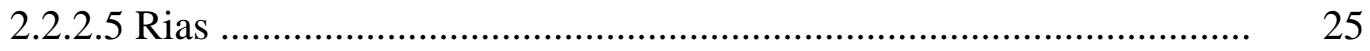

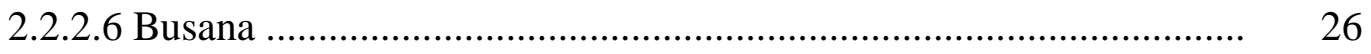

2.2.2.7 Properti dan Sesaji .............................................................. 26

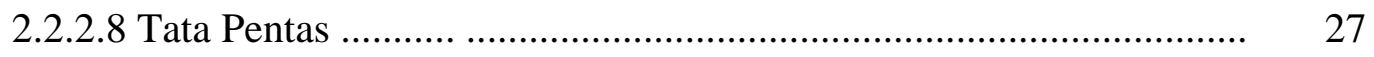

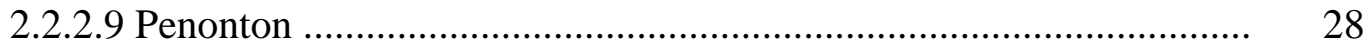

2.2.3 Kesenian Tradisional Kerakyatan................................................... 28

2.2.4 Pelestarian Seni Tradisi .............................................................. $\quad 30$

2.2.5 Kesenian Sintren Dangdut ........................................................ 33

2.2.6 Faktor Pendukung dan Penghambat Perubahan Bentuk Pertunjukan. 35

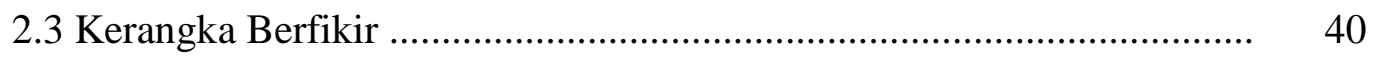


BAB 3 METODE PENELITIAN _...................................................... 42

3.1 Pendekatan Penelitian .................................................................. 43

3.2 Lokasi dan Sasaran Penelitian .......................................................... 45

3.2.1 Lokasi Penelitian ......................................................................... 45

3.2.2 Sasaran Penelitian ...................................................................... 45

3.3 Data dan Sumber Data ..................................................................... 46

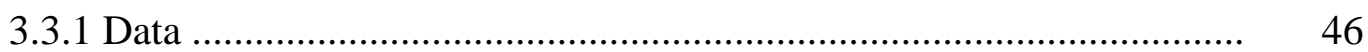

3.3.2 Sumber Data ..................................................................... 47

3.4 Teknik Pengumpulan Data ............................................................. 48

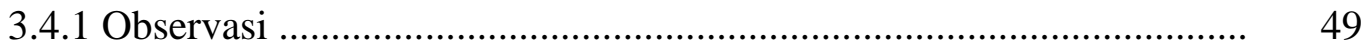

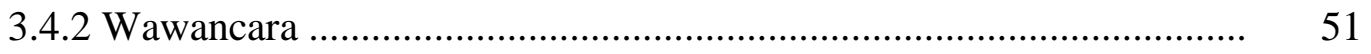

3.4.3 Dokumentasi ….............................................................. 53

3.5 Teknik Analisis Data ..................................................................... 54

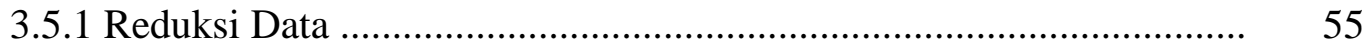

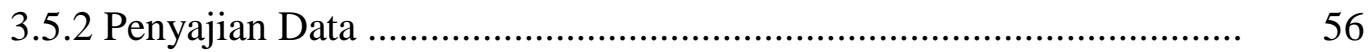

3.5.3 Penarikan Kesimpulan ................................................................. 56

3.6 Teknik Pemeriksaan Keabsahan Data ................................................ $\quad 59$

3.6.1 Triangulasi Sumber ................................................................ 59

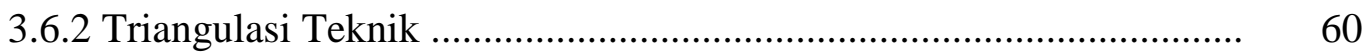

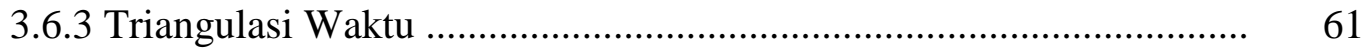

BAB 4 HASIL PENELITIAN DAN PEMBAHASAN ............................. 62

4.1 Gambaran Umum Kelurahan Pasarbatang Kabupaten Brebes ............. 62

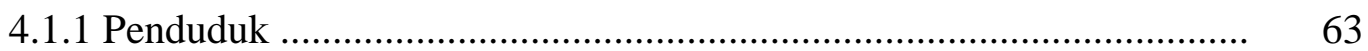




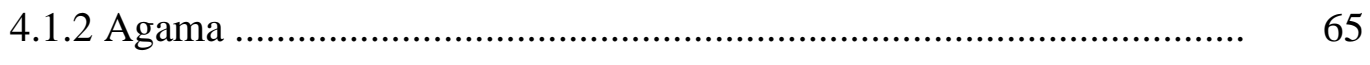

4.1.3 Mata Pencaharian .............................................................................. 66

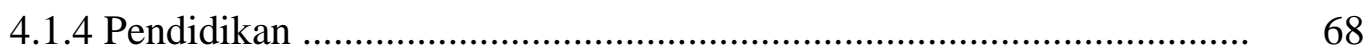

4.1.5 Kemasyarakatan .........................................................................

4.2 Profil Grup Kesenian Sintren Dangdut "Putra Kelana” .......................... 71

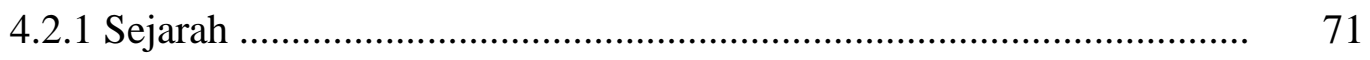

4.2.2 Kegiatan .....................................................................................

4.2.3 Struktur Organisasi ..........................................................................

4.3 Cerita Sintren ................................................................................

4.4 Bentuk Pertunjukan Kesenian Sintren Dangdut pada Grup Putra

Kelana di Kelurahan Pasarbatang Kabupaten Brebes ......................... 77

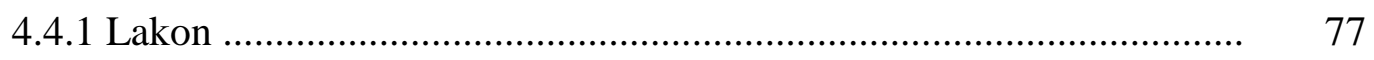

4.4.2 Gerak .....................................................................................

4.4.3 Pelaku ....................................................................................

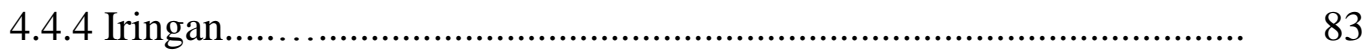

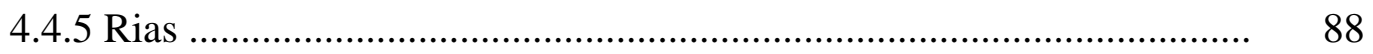

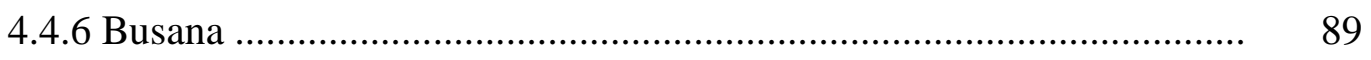

4.4.7 Tata Pentas ...................................................................................

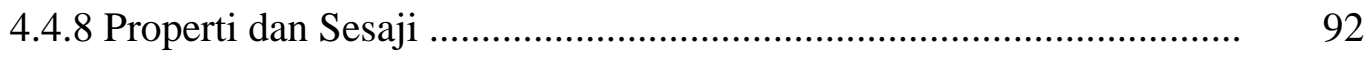

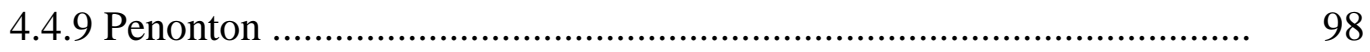

4.4.10 Urutan Pertunjukan Kesenian Sintren Dangdut ................................... 99

4.4.10.1 Awal Pertunjukan ………………………………....................... 99

4.4.10.2 Bagian Pertunjukan .................................................................. 101

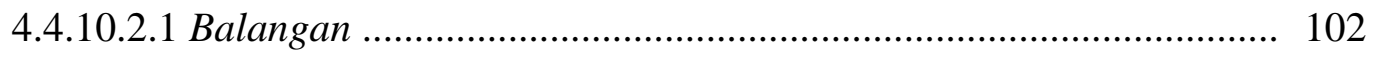




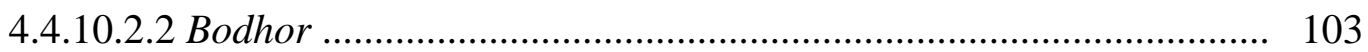

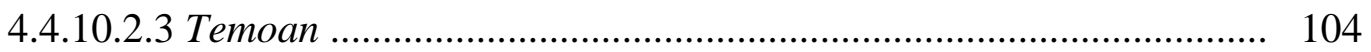

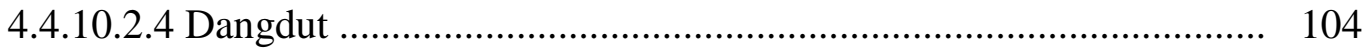

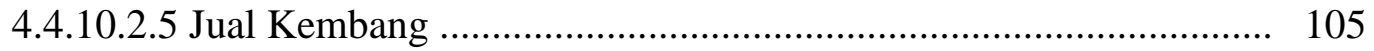

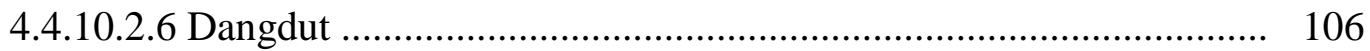

4.4.10.2.7 Sintren dan Bodhor Bertani ..................................................... 106

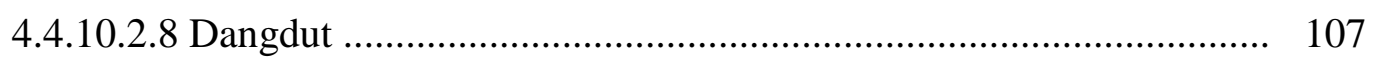

4.4.10.2.9 Ciri Khas Sintren Dangdut (Umbul-Umbul) ............................ 107

4.4.10.2.10 Naik Kurungan ............................................................... 108

4.4.10.3 Akhir Pertunjukan ................................................................. 109

4.4.10.3.1 Tangis-Tangis Layung ........................................................... 109

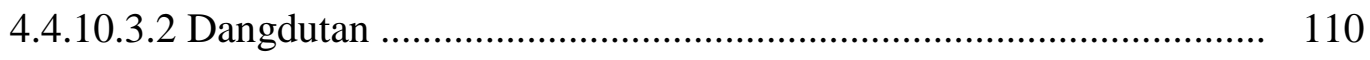

4.5 Upaya Pelestarian Seni Tradisi dalam Bentuk Pertunjukan Sintren

Dangdut Grup Putra Kelana di Kelurahan Pasarbatang Kabupaten

Brebes ..................................................................................... 110

4.5.1 Bentuk Perlindungan ............................................................ 112

4.5.2 Bentuk Pengembangan $\ldots \ldots \ldots \ldots \ldots \ldots \ldots \ldots \ldots \ldots \ldots \ldots \ldots \ldots \ldots, 114$

4.5.3 Bentuk Pemanfaatan ....................................... 116

4.6 Faktor Pendukung dan Faktor Penghambat Perubahan Bentuk

Pertunjukan Kesenian Sintren Dangdut Grup Putra Kelana di

Kelurahan Pasarbatang Kabupaten Brebes ......................................... 117

4.6.1 Faktor Pendukung Perubahan Bentuk Pertunjukan Kesenian

Sintren Dangdut

4.6.2 Faktor Penghambat Perubahan Bentuk Pertunjukan Kesenian

Sintren Dangdut ......................................................................... 119

BAB 5 SIMPULAN DAN SARAN .................................................. 121 


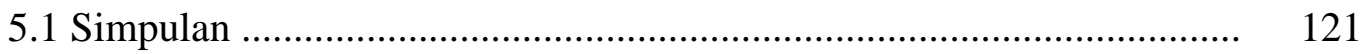

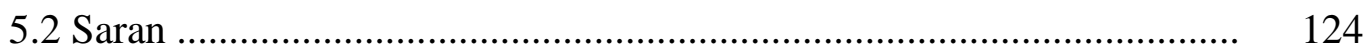

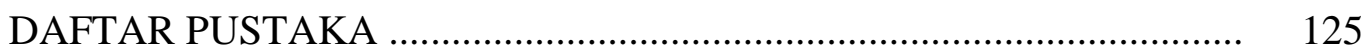

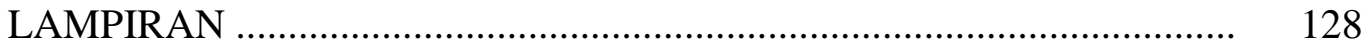

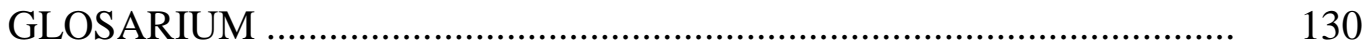




\section{DAFTAR TABEL}

Tabel

Halaman

3.1 Jumlah Penduduk Menurut Kelompok Umur ......................................... 63

3.2 Jumlah Penduduk Menurut Agama ..................................................... 66

3.3 Mata Pencaharian Penduduk Kelurahan Pasarbatang ......................... 67

3.4 Tingkat Pendidikan Kelurahan Pasarbatang ....................................... 69 


\section{DAFTAR FOTO}

Foto

Halaman

4.1 Tata Rias Sintren Dangdut .......................................................... 88

4.2 Busana Sintren Dangdut .............................................................. 90

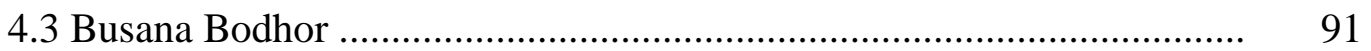

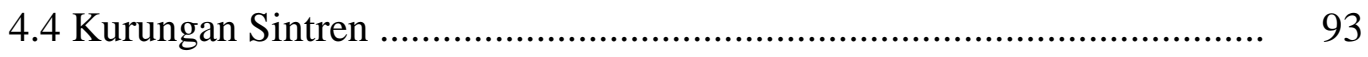

4.5 Kain Penutup Kurungan ................................................................. 94

4.6 Layah atau Anglo .......................................................................... 95

4.7 Arang Pada Pertunjukan Sintren Dangdut ........................................... 96

4.8 Sesaji Pada Pertunjukan Sintren Dangdut ............................................ 98

4.9 Sintren Sebelum Memasuki Kurungan ............................................ 99

4.10 Sintren Dangdut Sudah Berdandan Rapi ........................................ 100

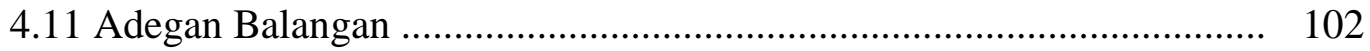

4.12 Sintren Dangdut Meminta Temoan ................................................... 104

4.13 Sintren Dangdut Saat Menari dengan Biduan dengan Musik Dangdut . 105

4.14 Sintren Dangdut dan Bodhor Menjual Kembang Melati .................... 106

4.15 Sintren Dangdut dan Bodhor sedang Bertani .................................. 107

4.16 Adegan Umbul-Umbul ............................................................... 108

4.17 Atraksi Sintren Dangdut dan Bodhor Naik Kurungan ........................ 109 


\section{DAFTAR LAMPIRAN}

Lampiran

Halaman

1. SK Penetapan Pembimbing ….......................................................... 130

2. Surat Ijin Penelitian ........................................................................ 131

3. Susunan Anggota Grup Kesenian Sintren Putra Kelana ....................... 132

4. Instrumen Penelitian ......................................................................... 133

5. Peta Indeks Kecamatan Brebes Kabupaten Brebes ................................ 138

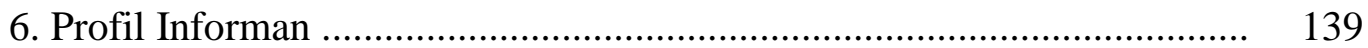

7. Dokumentasi Peneliti ......................................................................... 141

8. Surat Keterangan Penelitian ............................................................. 143

9. Transkip Wawancara …............................................................... 144

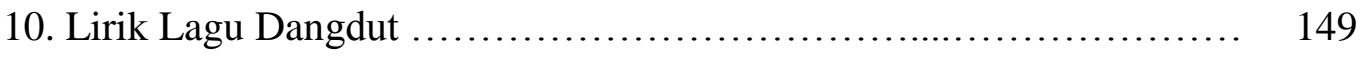

11. Biodata Peneliti ......................................................................... 152 


\section{BAB 1}

\section{PENDAHULUAN}

\subsection{Latar Belakang Masalah}

Kesenian merupakan salah satu unsur yang menyangga kebudayaan. Banyak ragam kesenian, suku dan bahasa yang ada di masyarakat pedalaman maupun perkotaan. Kesenian setiap daerah juga berbeda-beda tergantung kebiasaan masyarakat daerah itu sendiri. Ada banyak kebiasaan masyarakat daerah yang akhirnya menjadi ciri khas dari kesenian itu. Melalui keturunan yang ada di masyarakat, kesenian mulai dilestarikan bentuknya.

Pelestarian seni tradisi di Indonesia sangatlah penting agar kesenian tradisional tidak luntur dimakan oleh zaman. Melestarikan seni tradisi merupakan tugas dan kewajiban bersama sebagai masyarakat/bangsa Indonesia, termasuk pemerintah. Sangat penting dan sangat diperlukan keterlibatan semua komponen masyarakat untuk pelestariannya. Berbagai macam kesenian di Indonesia perlu dilestarikan.

Kesenian merupakan salah satu produk dari interaksi sosial. Kesenian dari suatu pola pikir masyarakat yang dikemas secara simbolis yang memiliki unsur estetika. Dari kesenian daerah, bisa diketahui pola pikir dan kebiasaan masyarakat dari daerah itu sendiri. Kesenian daerah bisa dikatakan sebagai identitas daerah tersebut. Seni berasal dari kata 'sani' dari bahasa Sansekerta yang berarti pemujaan, pelayanan permintaan, dan pencarian dengan hormat dan jujur (Jazuli, 2011:23). 
Kesenian tradisional merupakan bentuk seni yang bersumber dan berakar serta telah dirasakan sebagai milik sendiri oleh masyarakat di lingkungannya. Kesenian tradisional di Indonesia terbagi menjadi berpuluh-puluh kesenian daerah yang terdiri dari seni rakyat dan seni klasik (Sinaga, 2006:3).

Keberadaan kesenian tradisional pada dasarnya tidak pernah berdiri dan lepas dari masyarakat yang mempengaruhi dan mendukung kelangsungan hidup suatu kesenian. Kenyataannya kesenian yang ada di masyarakat diketahui dan tidak pernah dipastikan penciptanya, begitu musik rakyat atau tarian rakyat diciptakan, masyarakat segera meng-claim-nya sebagai pemiliknya (Kayam, 2003:39). Jadi kehadiran bentuk kesenian di tengah-tengah masyarakat berhubungan erat dengan kebutuhan hidup manusia, sehingga kesenian dalam arti luas dapat bermacam-macam fungsinya. Menurut Humardani (2003: 55-59) dalam kehidupan kesenian tradisi mempunyai fungsi utama atau primer yang khas pada seni yaitu hayatan atau ekspresi seni dan fungsi tambahan atau sekunder yang tidak khas pada seni, artinya keperluan upacara, peringatan, penerangan, pendidikan dan hiburan pelepas lelah.

Tujuan semula seni tradisional diciptakan adalah untuk menghambakan diri pada siklus kehidupan, serta memberikan daya keseimbangan kosmos yang spiritualistik. Realitanya, seni tradisional digunakan untuk upacara ritual, persembahan kepada Tuhan dan keselamatan atau kesejahteraan masyarakat (Sutiyono, 2009: 77). 
Melestarikan seni tradisional bukan hanya semata-mata menjadi kepentingan dan tanggungjawab pemerintah, namun juga kewajiban semua lapisan masyarakat. Khususnya generasi muda sebagai elemen yang sangat penting dalam melestarikan kebudayaan yang ada di Indonesia dan sekaligus berkontribusi sangat besar dalam pembangunan bangsa dan negara Indonesia. Pemberdayaan generasi muda sebagai frontliner untuk melestarikan kebudayaan bangsa Indonesia ini sangat dibutuhkan sebagai upaya mempercepat kemajuan untuk dunia industri budaya dan pariwisata Indonesia di masa yang akan datang.

Banyak juga dari wisatawan asing pergi atau berlibur ke Indonesia karena di Indonesia banyak aneka ragam objek wisata meliputi wisata budaya dan wisata alam. Biasanya di tempat tujuan, seorang wisatawan hanya tinggal dalam waktu yang relatif singkat, dan salah satu ragam objek wisata adalah warisan budaya setempat, antara lain seni pertunjukan tradisional. Oleh karena waktu yang sangat terbatas, serta biasanya memiliki latar belakang budaya yang lain, maka seni pertunjukan tradisional yang dikemas haruslah menghibur, menarik serta tidak memakan waktu lama, seperti yang disampaikan oleh Soedarsono (2002: 273) sebagai anggota masyarakat seni pertunjukan tradisional bagi masyarakat wisata memiliki ciri-ciri: (1) tiruan dari aslinya; (2) versi singkat atau padat; (3) dikesampingkan nilai-nilai sakral, magis, dan simbolisnya atau nilai primernya; (4) penuh variasi; (5) disajikan dengan menarik; dan (6) murah harganya menurut kocek wisatawan.

Kesenian Sintren merupakan salah satu bentuk seni pertunjukan di Indonesia yang berkembang di daerah pesisir pulau Jawa seperti Cirebon, 
Indramayu, Brebes, Pemalang, Pekalongan, dan Batang. Kesenian Sintren bermula dari legenda percintaan Sulasih dan Raden Sulandono seorang putra bupati di Mataram yang bernama Bahurekso dan Rr. Rantamsari. Percintaan Sulasih dan Raden Sulandono tidak direstui oleh ayahnya yaitu Bahurekso, sehingga Raden Sulandono diperintahkan oleh ibunya untuk bertapa dan diberikan selembar kain (sapu tangan) sebagai sarana kelak untuk bertemu dengan Sulasih setelah masa bertapanya selesai, sedangkan Sulasih diperintahkan untuk menjadi penari pada setiap acara bersih desa yang diadakan sebagai syarat dapat bertemu Raden Sulandono (wawancara Bapak Dalang, April 2016). Sintren merupakan kesenian yang mengandung unsur magis karena dalam pertunjukan Sintren menggunakan doa-doa dan mantera yang oleh masyarakat di pedesaan dipergunakan untuk acara yang dianggap sakral, seperti ritual untuk meminta hujan, meminta jodoh dan sebagai sarana untuk menyembuhkan penyakit dan sebagai hiburan masyarakat.

Grup Putra Kelana mengemas kesenian sintren sedemikian rupa agar para penonton atau penikmat kesenian tidak bosan. Grup Putra Kelana berdiri sejak tahun 1980-an dengan dipimpin oleh Bapak Dalang Wertadiharjo. Awalnya pertunjukan kesenian Sintren ini sama dengan kesenian Sintren di daerah pantura yang lain, namun ada gejala yang menunjukan masyarakat mulai kurang tertarik terhadap pertunjukan, sehingga Grup Putra Kelana mengkolaborasikan pertunjukan Sintren dengan dangdut. Penelitian ini dilaksanakan karena masyarakat masih menyukai gabungan kesenian Sintren dengan dangdut tersebut, 
kemudian gabungan kesenian ini diberi nama kesenian Sintren Dangdut yang membedakan kesenian Sintren lain.

Kesenian Sintren Dangdut gabungan dari kesenian Sintren dengan Dangdut, jadi dalam pertunjukannya bukan hanya sekedar Sintren melainkan pertunjukan Dangdut ikut bergabung bersamanya. Gabungan dari Sintren dengan Dangdut ini adalah upaya pelestarian seni tradisi yang ada di Kabupaten Brebes. Pertunjukan Sintren Dangdut pada acara khitanan ataupun nikahan ketertarikan penonton lebih ke hiburan pada musik dangdutnya, sedangkan pada acara seperti upacara sedekah bumi ketertarikan penonton lebih pada pertunjukan Sintrennya. Jadi pertunjukan Sintren Dangdut tampil bergantung pada minat atau ketertarikan penonton yang akan melihat. Peneliti mengambil data dari pertunjukan Sintren Dangdut pada acara hajatan dan lebih mengutamakan hiburan.

Bentuk pertunjukan merupakan keseluruhan dari pertunjukan mulai dari awal sampai akhir. Dari sinilah peneliti tertarik dengan bentuk pertunjukan kesenian Sintren Dangdut yang ada di Kabupaten Brebes. Peneliti meneliti tentang "Bentuk Pertunjukan Kesenian Sintren Dangdut Sebagai Upaya Pelestarian Seni Tradisi Pada Grup Putra Kelana Di Kelurahan Pasarbatang Kabupaten Brebes".

\subsection{Rumusan Masalah}

Berdasarkan uraian latar belakang yang telah disebutkan sebelumnya, maka masalah yang dibahas adalah :

(1) Bagaimana bentuk pertunjukan kesenian Sintren Dangdut pada grup Putra Kelana di Kelurahan Pasarbatang Kabupaten Brebes? 
(2) Bagaimana upaya pelestarian seni tradisi dalam bentuk pertunjukan kesenian Sintren Dangdut pada grup Putra Kelana di Kelurahan Pasarbatang Kabupaten Brebes?

(3) Faktor-faktor apakah yang menjadi pendukung dan penghambat bentuk pertunjukan kesenian Sintren Dangdut sebagai upaya pelestarian seni tradisi pada grup Putra Kelana di Kelurahan Pasarbatang Kabupaten Brebes?

\subsection{Tujuan Penelitian}

Berkaitan dengan permasalahan, maka tujuan penelitian ini adalah :

(1) Untuk mengetahui dan mendeskripsikan bentuk pertunjukan kesenian Sintren Dangdut pada grup Putra Kelana di Kelurahan Pasarbatang Kabupaten Brebes.

(2) Untuk mengetahui dan mendeskripsikan upaya pelestarian seni tradisi dalam bentuk pertunjukan kesenian Sintren Dangdut pada grup Putra Kelana di Kelurahan Pasarbatang Kabupaten Brebes.

(3) Untuk mengetahui dan mendeskripsikan faktor-faktor yang menjadi pendukung dan penghambat bentuk pertunjukan kesenian Sintren Dangdut sebagai upaya pelestarian seni tradisi pada grup Putra Kelana di Pasarbatang Kabupaten Brebes.

\subsection{Manfaat Penelitian}

\subsubsection{Manfaat teoritis}

(1) Penelitian ini diharapkan dapat memberikan informasi kepada pembaca mengenai bentuk seni pertunjukan. Dari informasi tersebut pada akhirnya akan memberikan sumbangan bagi ilmu pengetahuan khususnya tentang 
bentuk seni pertunjukan, serta dapat digunakan oleh peneliti lain untuk pengembangan selanjutnya.

(2) Sebagai sumbangan pemikiran bagi lembaga pendidikan tinggi Universitas Negeri Semarang khususnya mahasiswa Jurusan Pendidikan Seni Drama, Tari dan Musik untuk lebih mengenal bentuk pertunjukan kesenian Sintren Dangdut.

(3) Memberikan informasi tertulis bagi masyarakat umum, khususnya generasi muda sebagai pewaris serta penerus kebudayaan bangsa sehingga dapat mengenal bentuk pertunjukan kesenian Sintren Dangdut.

\subsubsection{Manfaat praktis}

(1) Menjadi pengetahuan bagi masyarakat dan guru khususnya seni budaya untuk diinformasikan kepada peserta didik dalam pelajaran seni budaya. Diharapkan setelah peserta didik mengetahui, maka akan tumbuh rasa cinta pada kesenian tradisional, dan ikut serta menjadi pelaku sebagai perwujudan rasa cinta tanah air yang belakangan ini semakin mengkhawatirkan.

(2) Penelitian ini diharapkan mampu memberikan semangat kepada masyarakat Kelurahan Pasarbatang untuk berpartisipasi lebih aktif dalam pertunjukan seni tradisi kerakyatan.

(3) Pemerintah Kelurahan Pasarbatang, agar semakin mendukung pertunjukan seni yang dilaksanakan di Kelurahan Pasarbatang sebagai upaya untuk melestarikan kesenian tradisional di daerah setempat.

(4) Dinas Pariwisata Kabupaten Brebes, agar semakin mendukung dan memberikan perhatian pada pengembangan kesenian tradisi kerakyatan 
dengan mengadakan acara pentas rutin di Kelurahan Pasarbatang yang berdampak pada meningkatnya daya tarik wisatawan untuk berkunjung di Brebes.

\subsection{Sistematika Penulisan Skripsi}

Sistematika skripsi adalah urutan pokok persoalan maupun langkahlangkah pembicaraan atau pembahasan yang akan disajikan dalam bab-bab yang merangkum dalam suatu skripsi. Hasil penelitian yang dilakukan disusun dalam bentuk skripsi yang terdiri dari tiga bagian, yaitu bagian awal, bagian isi, dan bagian akhir.

Adapun sistematika skripsi yang dimaksud adalah sebagai berikut:

Bagian awal terdiri dari Halaman Judul, Halaman Pengesahan, Halaman Motto dan Persembahan, Sari, Prakata, Daftar Isi, dan Daftar Lampiran.

Bagian isi terdiri dari 5 bab, yaitu Pendahuluan, Tinjauan Pustaka dan Landasan Teoretis, Metode Penelitian, Hasil Penelitian dan Pembahasan, serta Kesimpulan dan Saran-saran.

Bab 1. Pendahuluan yang berisi : Latar belakang masalah, Rumusan Masalah, Tujuan Penelitian, Manfaat Penelitian, dan Sistematika Penulisan Skripsi.

Bab 2. Berisi Tinjauan Pustaka dan Landasan Teoritis yang terdiri dari :Pustaka yang dikaji dari buku, artikel, skripsi, tesis, jurnal, makalah, disertasi, dan laporan penelitian. Memuat teori-teori yang berisi telaah pustaka yang berhubungan dengan masalah yang dibahas dalam penelitian ini meliputi: bentuk pertunjukan, unsur-unsur pertunjukan tari, kesenian tradisional, pelestarian seni tradisi, upaya 
pelestarian seni tradisi, kesenian sintren, pengertian dangdut, dan faktor pendukung dan penghambat perubahan bentuk pertunjukan.

Bab 3. Berisi metode penelitian berisi tentang prosedur penelitian yang meliputi: Pendekatan Penelitian, Lokasi Peneliti, Teknik Pengumpulan Data, Teknik Analisa Data, Teknik Pemeriksaan Keabsahan Data.

Bab 4. Hasil penelitian dan pembahasan, memuat data-data yang diperoleh sebagai hasil dari penelitian, pelaksanaan proses bentuk pertunjukan kesenian Sintren Dangdut sebagai upaya pelestarian seni tradisi pada grup Putra Kelana di Kelurahan Pasarbatang Kabupaten Brebes.

Bab 5. Berisi tentang kesimpulan penelitian yang telah dilakukan serta saran-saran yang diberikan berdasarkan hasil penelitian yang mungkin dapat memajukan seni pertunjukan di Indonesia.

Bagian akhir skripsi ini di isi dengan Daftar Pustaka dan bagian-bagian lampiran. 


\section{BAB 2}

\section{TINJAUAN PUSTAKA DAN LANDASAN TEORETIS}

\subsection{Tinjauan Pustaka}

Kesenian yang berkembang pada suatu daerah dan masih dilestarikan menjadi faktor pendorong bagi peneliti-peneliti untuk mengupas lebih jauh tentang kesenian tersebut. Kesenian tradisional Sintren Dangdut merupakan salah satu kesenian yang berada di Kelurahan Pasarbatang Kabupaten Brebes yang masih dipertahankan sampai sekarang. Penelitian yang sama juga dilakukan oleh Bagus Indrawan pada tahun 2013 tentang "Bentuk dan Fungsi Pertunjukan Musik Pengiring Seni Sintren Lais di Desa Balapulang Kulon Kabupaten Tegal”. Rumusan masalah yang diangkat yaitu Bagaimana bentuk pertunjukan musik pengiring seni Sintren Lais di desa Balapulang Kulon kabupaten Tegal? dengan Bagaimana fungsi musik pengiring seni Sintren Lais di desa Balapulang Kulon Kabupaten Tegal?. Tujuan penelitian ini yaitu untuk mengetahui dan mendeskripsikan bentuk pertunjukan dan fungsi musik pengiring seni Sintren Lais di desa Balapulang Kulon kabupaten Tegal. Hasil dari penelitian ini yaitu bentuk komposisi musik dan bentuk penyajian. Bentuk komposisi musik pengiring kesenian Sintren Lais terdiri dari ritme, melodi, harmoni, struktur bentuk analisa musik pengiring, syair, tempo, dinamika, dan ekspresi, instrumen, arasemen, dan pemain, sedangkan bentuk penyajian terdiri dari sajen, urutan penyajian, tata panggung, dan waktu pertunjukan, tata rias, tata busana, tata suara, tata lampu, dan penonton. 
Persamaan antara penelitian bentuk dan fungsi pertunjukan pengiring musik oleh Bagus Indrawan dengan bentuk pertunjukan kesenian Sintren Dangdut sebagai upaya pelestarian seni tradisi adalah sama-sama meneliti tentang bentuk pertunjukan kesenian Sintren. Perbedaan pada penelititian bentuk dan fungsi pertunjukan pengiring musik oleh Bagus Indrawan adalah meneliti tentang bentuk komposisi musik pengiring dan bentuk penyajian kesenian Sintren sedangkan penelitian bentuk pertunjukan kesenian Sintren Dangdut sebagai upaya pelestarian seni tradisi adalah meneliti tentang bentuk pertunjukan yang didalamnya mencakup urutan pertunjukan kesenian Sintren Dangdut serta meneliti tentang upaya pelestarian seni tradisi pada bentuk pertunjukan kesenian Sintren Dangdut, kesenian Sintrennya juga terdapat selingan musik dangdut.

Penelitian Zaenal Arifin pada tahun 2015 tentang "Bentuk Pertunjukan Dan Fungsi Kesenian Musik Rebana Grup Asy-Syabab Di Desa Trahan Kecamatan Sluke Kabupaten Rembang”. Permasalahan yang diangkat adalah Bagaimana bentuk pertunjukan dan fungsi kesenian Musik Rebana Grup AsySyabab di Desa Trahan Kecamatan Sluke Kabupaten Rembang?.

Hasil yang didapat dari penelitian bentuk pertunjukan dan fungsi kesenian Musik Rebana Grup Asy-Syabab di Desa Trahan Kecamatan Sluke Kabupaten Rembang adalah kesenian Musik Rebana Grup Asy-Syabab dalam bentuk pertunjukan terdiri dari dua aspek yaitu aspek tekstual dan aspek kontekstual. Aspek tekstual dalam kesenian Musik Rebana Grup Asy-Syabab terbagi menjadi dua aspek yaitu aspek komposisi dan aspek penyajian. Aspek komposisi pada kesenian Musik Rebana Grup Asy-Syabab meliputi irama ritme yang terdiri" dari 
delapan pola ritme, melodi yang digunakan adalah melodi yang bersumber pada vokal dan vokal pendamping, dan syair yang digunakan adalah bacaan sholawat dan lagu-lagu yang bernafaskan islami yang mengandung syi'ar. Alat musik yang terdiri dari 4 rebana, 2 teplak, I bass dan 1 tambourine, pemain yang terdiri dari 8 pemain musik, 2 vokal utama dan 10 backing vokal, penonton, perlengkapan pementasan, urutan penyajian, tata panggung, tata rias, tata busana, tata suara, tata cahaya dan formasi. Sedangkan aspek penyajian merupakan susunan dari bagian keseluruhan dari pementasan atau pertunjukan yang di dalamnya yang terdiri dari bagian pembukaan, bagian utama, dan bagian akhir.

Persamaan antara penelitian bentuk pertunjukan dan fungsi kesenian Musik Rebana Grup Asy-Syabab sebagai media dakwah dengan bentuk pertunjukan kesenian Sintren Dangdut sebagai upaya pelestarian seni tradisi adalah sama-sama meneliti tentang bentuk pertunjukan. Perbedaan pada penelitian bentuk pertunjukan dan fungsi kesenian Musik Rebana Grup Asy-Syabab sebagai media dakwah adalah meneliti tentang bentuk pertunjukan dan fungsi kesenian Musik Rebana Grup Asy-Syabab yang didalamnya mencakup urutan bentuk penyajian dan fungsi sedangkan penelitian bentuk pertunjukan kesenian Sintren Dangdut sebagai upaya pelestarian seni tradisi adalah meneliti tentang bentuk pertunjukan yang didalamnya mencakup urutan pertunjukan kesenian Sintren Dangdut serta meneliti tentang upaya pelestarian seni tradisi pada bentuk pertunjukan kesenian Sintren Dangdut.

Peneliti Krisna Dewi Mustikasari pada tahun 2013 tentang "Fungsi Musik Iringan dalam Kesenian Sintren Di Desa Pagejugan Kabupaten Brebes". 
Permasalahan yang diangkat adalah (1) Bagaimana bentuk fungsi musik iringan dalam kesenian Sintren di Desa Pagejugan Kabupaten Brebes?.

Hasil yang didapat dari penelitian fungsi musik iringan dalam kesenian Sintren di Desa Pagejugan Kabupaten Brebes adalah fungsi musik iringan kesenian sintren dibagi menjadi dua yaitu, fungsi musik iringan bagi kesenian itu sendiri, dan fungsi musik iringan bagi masyarakat pendukungnya. Fungsi musik iringan bagi kesenian itu sendiri adalah fungsi yang berhubungan dengan bentuk musik dan proses pertunjukan sintren. Fungsi musik bagi masyarakat pendukungnya adalah (1) sebagai sarana komunikasi yaitu komunikasi terhadap sesama manusia melalui lantunan syair lagu yang dibawakan sinden dimana beberapa syair lagu yang menyentuh berbagai aspek kehidupan sosial, (2) sebagai sarana hiburan yaitu penyajian musik iringan sintren menimbulkan suasana yang lebih meriah dan menarik minat masyarakat, (3) sebagai penghayatan estetis yaitu melalui musik kita dapat mengenal nilai - nilai keindahan baik melalui melodi ataupun dinamikanya.

Persamaan antara penelitian fungsi musik iringan dalam kesenian Sintren dengan bentuk pertunjukan kesenian Sintren Dangdut sebagai upaya pelestarian seni tradisi adalah sama-sama meneliti tentang kesenian Sintren. Perbedaan pada penelitian fungsi musik iringan dalam kesenian Sintren adalah meneliti tentang bentuk musik iringan kesenian Sintren serta fungsi musik iringan kesenian Sintren sedangkan penelitian bentuk pertunjukan kesenian Sintren Dangdut sebagai upaya pelestarian seni tradisi adalah meneliti tentang bentuk pertunjukan yang didalamnya mencakup urutan pertunjukan kesenian Sintren Dangdut serta 
meneliti tentang upaya pelestarian seni tradisi pada bentuk pertunjukan kesenian Sintren Dangdut, kesenian Sintrennya juga terdapat selingan musik dangdut.

Penelitian Eny Kusumastuti pada tahun 2006 tentang "Laesan sebuah Fenomena Kesenian Pesisir : Kajian Interaksi Simbolik antara Pemain dan Penonton”. Salah satu permasalahan yang diangkat adalah (1) Bagaimana bentuk penyajian kesenian Laesan di Desa Bajomulyo, Kecamatan Juwana, Kabupaten Pati?.

Hasil yang didapat dari Laesan sebuah fenomena kesenian Pesisir : Kajian Interaksi Simbolik antara pemain dan penonton adalah kesenian Laesan merupakan kesenian masyarakat pesisir yang dipakai sebagai media untuk mendekatkan diri dengan Tuhan dan tempat untuk melakukan proses interaksi simbolik antara pemain dan penonton, yang ditunjukkan dengan segala perlengkapan pentas, bentuk penyajian, dan makna simbolik yang terkandung di dalamnya. Perlengkapan pentas yang disediakan terdiri dari dupa, lengkap dengan sesajinya, yang merupakan syarat untuk dapat melakukan hubungan dengan roh nenek moyang. Simbol yang muncul dalam proses interaksi antara pemain dan penonton adalah simbol kesuburan yang ditunjukkan melalui atraksi Laes menusukkan keris ketubuhnya. Di samping itu, kesenian Laesan juga mempunyai nilai pendidikan budi pekerti yang terkandung dalam setiap syair lagu yang mengiringi pertunjukan Laesan.

Persamaan antara penelitian Laesan sebuah fenomena kesenian pesisir : kajian interaksi simbolik antara pemain dan penonton dengan bentuk pertunjukan kesenian Sintren Dangdut sebagai upaya pelestarian seni tradisi adalah sama-sama 
meneliti tentang kesenian tradisional kerakyatan yang hidup di masyarakat pesisir. Di pesisir barat, kesenian Laesan mempunyai perbedaan yang terletak pada pemeran utamanya. Pemeran utama pada kesenian Laesan adalah seorang laki-laki yang disebut dengan Lais, sementara di pesisir barat pemeran utama dalam kesenian tersebut adalah perempuan yang kemudian disebut Sintren. Perbedaan pada penelititian Laesan sebuah fenomena kesenian pesisir : kajian interaksi simbolik antara pemain dan penonton adalah meneliti tentang proses interaksi simbolik antara pemain dan penonton yang ditunjukkan dengan perlengkapan pentas, bentuk penyajian dan makna simbolik yang terkandung dalam kesenian Laesan sedangkan penelitian bentuk pertunjukan kesenian Sintren Dangdut sebagai upaya pelestarian seni tradisi adalah meneliti tentang bentuk pertunjukan yang didalamnya mencakup urutan pertunjukan kesenian Sintren Dangdut serta meneliti tentang upaya pelestarian seni tradisi pada bentuk pertunjukan kesenian Sintren Dangdut, kesenian Sintrennya juga terdapat selingan musik dangdut.

Peneliti Syahrul Syah Sinaga pada tahun 2006 tentang "Fungsi dan Ciri Khas Kesenian Rebana di Pantura Jawa Tengah". Permasalahan yang diangkat adalah (1) Bagaimana fungsi dan ciri khas kesenian Rebana di Pantura Jawa Tengah?.

Hasil yang didapat dari penelitian fungsi dan ciri khas kesenian Rebana di pantura Jawa Tengah adalah kesenian Rebana merupakan salah satu jenis dari berbagai kesenian tradisional yang bernafaskan Islam yang cukup pesat berkembang di Jawa Tengah khususnya di daerah Pantura. Kesenian ini menurut fungsinya sangat berarti bagi masyarakat pendukungnya di samping sebagai 
media dakwah, dzikir, berfungsi pula sebagai sarana hiburan baik bagi masyarakat pelaku maupun pengguna kesenian Rebana yang berkembang di Pntura Jawa Tengah pada kenyataannya terbagi menjadi tiga versi yaitu versi Pekalongan, Semarangan, dan Demak sebagai hasil dari akibat akulturasi budaya atau kontak budaya, seperti adanya penambahan alat musik barat, bentuk dan irama musik, syair atau lirik yang dibawakan.

Persamaan antara penelitian fungsi dan ciri khas kesenian Rebana di pantura Jawa Tengah dengan bentuk pertunjukan kesenian Sintren Dangdut sebagai upaya pelestarian seni tradisi adalah sama-sama meneliti tentang kesenian dari Jawa Tengah di daerah pantura. Perbedaan pada penelititian fungsi dan ciri khas kesenian Rebana di pantura Jawa Tengah adalah meneliti tentang fungsi dan ciri khas kesenian Rebana sedangkan penelitian bentuk pertunjukan kesenian Sintren Dangdut sebagai upaya pelestarian seni tradisi adalah meneliti tentang bentuk pertunjukan yang didalamnya mencakup urutan pertunjukan kesenian Sintren Dangdut serta meneliti tentang upaya pelestarian seni tradisi pada bentuk pertunjukan kesenian Sintren Dangdut, kesenian Sintrennya juga terdapat selingan musik dangdut.

\subsection{Landasan Teoretis}

Landasan teoretis berisi tentang teori-teori yang dibahas dalam penelitian, meliputi: (1) bentuk pertunjukan, (2) Unsur-unsur seni pertunjukan, (3) kesenian tradisional kerakyatan, (4) pelestarian seni tradisi, (5) kesenian sintren dangdut, (6) faktor pendukung dan penghambat perubahan bentuk pertunjukan. 


\subsubsection{Bentuk Pertunjukan}

Kata "bentuk" dalam Kamus Besar Bahasa Indonesia (2005: 135) mempunyai arti gambaran, wujud, susunan. Pertunjukan mempunyai arti sesuatu yang dipertunjukan, tontonan (bioskop, wayang, dan sebagainya), maka dapat disimpulkan bentuk pertunjukan adalah gambaran dari sesuatu yang dipertunjukan.

Bentuk tidak terlepas dari keberadaan struktur, yaitu susunan dari unsur atau aspek (bahan/material baku dan aspek pendukung lainnya) sehingga mewujudkan suatu bentuk. Anggota tubuh merupakan struktur yang terdiri atas kepala, badan, lengan, tangan, jari-jari tangan dan kaki dapat menghasilkan suatu bentuk gerak yang indah dan menarik bila ditata, dirangkai dan disatupadukan ke dalam sebuah kesatuan susunan gerak yang utuh serta selaras dengan unsur-unsur pendukung penampilan tari (Jazuli, 2008: 7).

Bentuk dalam tari merupakan wujud keseluruhan dari sistem, kompleksitas berbagai unsur-unsurnya yang membentuk suatu jalinan atau kesatuan, saling terkait secara utuh, sehingga mampu memberikan daya apresiasi (Maryono, 2012: 90). Pertunjukan adalah sesuatu yang dipertunjukan, dipertontonkan, atau dipamerkan kepada khalayak. Tujuannya untuk memberi suatu seni, informasi, atau hiburan. Seni pertunjukan adalah sesuatu yang bernilai seni tetapi senantiasa berusaha untuk menarik perhatian bila ditonton (Jazuli, 2008: 59). 
Soedarsono (2001: 5) mengatakan bahwa sebuah pertunjukan merupakan perpaduan antara berbagai aspek penting yang menunjang seperti lakon, pemain (pelaku), busana, iringan, tempat pentas, dan penonton. Kusmayati (2000: 75) mengatakan bahwa pertunjukan merupakan aspek-aspek yang divisualisasikan dan diperdengarkan yang mampu mendasari suatu perwujudan. Aspek-aspek ini menyatu menjadi suatu keutuhan di dalam penyajiannya yang menunjukkan suatu intensitas atau kesungguhan ketika diketengahkan sebagai bagian dari penompang perwujudan keindahan. Aspek-aspek tersebut terdiri dari pelaku, gerak, suara, dan rupa.

Berdasarkan uraian diatas dapat disimpulkan bahwa peneliti mengambil atau memadukan dua konsep antara teori Soedarsono dengan teori Kusmayati. Bentuk pertunjukan merupakan segala sesuatu yang ditampilkan atau ditonton dan memberikan daya apresiasi didalamnya mengandung unsur-unsur keindahan yang disampaikan oleh pencipta kepada penikmat kesenain. Perpaduan antara dua konsep itu memiliki unsur-unsur bentuk pertunjukan meliputi, lakon, gerak, pelaku, iringan, rupa (rias, busana, properti, sesaji), tata pentas, dan penonton.

\subsubsection{Unsur-Unsur Seni Pertunjukan}

Unsur-unsur seni pertunjukan dalam sebuah kesenian tradisional kerakyatan antara lain: lakon, gerak, pelaku, iringan, rupa (rias, busana, properti, sesaji), tata pentas, dan penonton (Soedarsono, 2001: 5; Kusmayati, 2000: 75).

\subsubsection{Lakon}

Lakon merupakan peristiwa atau karangan yang disampaikan kembali dengan tindak tanduk melalui benda perantara hidup (manusia) atau suatu 
(boneka, wayang) sebagai pemain: pertunjukan wayang kulit dengan Baratayuda, lakon juga disebut sebagai peran utama (Kamus Besar Bahasa Indonesia, 2005: 876)

\subsubsection{Gerak}

Gerak merupakan gejala yang paling primer dari kehidupan manusia, dan gerak merupakan media yang paling tua dari manusia untuk menyatakan keinginan, atau merupakan bentuk refleksi spontan dari gerak batin manusia. Gerak juga merupakan alat komunikasi yang mengawali tanda-tanda adanya kehidupan manusia, hal ini dapat diperhatikan sejak kelahiran seorang bayi, bayi akan melakukan gerakan, sebagai tanda bahwa bayi hidup, bahkan seorang bayi akan berkomunikasi kepada ibunya dengan gerak (Rokhana, 2014: 35).

Gerak merupakan unsur penunjang yang paling besar peranannya dalam seni tari. Dengan gerak terjadinya perubahan tempat, perubahan posisi dari benda, tubuh penari atau sebagian dari tubuh. Semua gerak melibatkan ruang dan waktu. Dalam ruang sesuatu yang bergerak menempuh jarak tertentu, dan jarak dalam waktu tertentu ditentukan oleh kecepatan gerak (Djelantik, 1999: 27).

Gerak terkandung tenaga/energi yang melibatkan ruang dan waktu. Artinya gejala yang menimbulkan gerak adalah tenaga, bergerak berarti memerlukan ruang dan membutuhkan waktu ketika proses gerak berlangsung (Jazuli, 2008: 8). Bentuk gerak sederhana menjadi ciri untuk sebagian kesenian tradisional kerakyatan (Sedyawati, 1986:171)

Lanjut menurut Jazuli (2008: 8) bahwa gerak ada dua jenis, yaitu gerak murni dan gerak maknawi. Gerak murni (pure movoment) atau disebut gerak 
wantah adalah gerak yang disusun dengan tujuan untuk mendapatkan bentuk artistik (keindahan) dan tidak mempunyai maksud-maksud tertentu. Gerak maknawi (gesture) atau disebut gerak tidak wantah adalah gerak yang mengandung arti atau maksud tertentu dan telah distilasi (dari wantah menjadi tidak wantah).

\section{Tenaga}

Semua gerak memerlukan tenaga, untuk gerak tubuh penari diambil tenaga dari sang penari harus selalu siap mengeluarkan tenaga atau energi yang sesuai (Djelantik, 1990: 27). Tenaga merupakan sebuah gerak dapat dilakukan dengan tenaga besar, sedikit, atau sedang, masing-masing memberikan kesan rasa yang berbeda (Murgiyanto, 2004: 55).

1) Intensitas

Penggunaan tenaga yang besar menghasilkan gerak yang bersemangat dan kuat, sebaliknya penggunaan tenaga yang sedikit mengurangi rasa kegairahan, keyakinan dan kemantapan. Intensitas adalah banyak sedikitnya tenaga yang digunakan dalam sebuah gerak (Murgiyanto, 1983: 27).

2) Aksen atau Tekanan

Aksen atau tekanan adalah bagian-bagian titik gerakan yang terjadi karena penggunaan tenaga yang tidak rata, artinya ada gerakan yang menggunakan tenaga sedikit ada pula yang banyak. Fungsi tekanan gerak berguna untuk membedakan antara gerak yang satu dengan yang lainnya, atau berlawanan dalam penggunaan tenaga dengan sebelumnya (Murgiyanto, 1983: 27) 
3) Kualitas

Kualitas-kualitas gerak tertentu menimbulkan rasa-rasa tertentu. Ketiga elemen gerak ruang, waktu dan tenaga tidak terpisahkan di dalam gerak tubuh. Ketiganya terangkai secara khas sebagai penentu "kualitas gerak". Kita dapat berjalan perlahan-lahan (waktu), dengan langkah lebar (ruang), dan santai (tenaga); atau sebaliknya kita dapat berlari dengan cepat (waktu), dengan langkah kecil-kecil (ruang), dan dengan tenaga penuh (tenaga). Dari kombinasi cara menggunakan ruang, waktu, dan tenaga, kita mengenal kualitas-kualitas gerak seperti, lembam, mengayun, bergetar, mengambang, dan memukul (Murgiyanto, 2004: 55-56)

\section{Ruang}

Ruang adalah sesuatu yang tidak bergerak dan diam sampai gerak yang terjadi didalamnya mengintrodusir waktu dengancara demikian mewujudkan ruang sebagai suatu bentuk, suatu ekspresi khusus yang berhubungan dengan waktu yang dinamis dari gerakannya (Hadi, 1996: 143). Dalam seni tari penataan ruang ditambah dengan penataan para pelaku, penataan gerak, warna, suara dan waktu, kesemuanya dicakup dengan kata koreografi. Ruang berkaitan dengan tempat yang mempunyai tiga dimensi yaitu: panjang, lebar, dan tinggi (Djelantik, 1999: 24).

Ruang dalam seni tari dapat dibedakan menjadi dua yaitu ruang yang diciptakan oleh penari itu sendiri adalah ruang yang langsung berhubungan dengan penari, batasan penari di tempat, batasan tangan dan kaki penari itu sendiri saat menari, kemudian ruang pentas yaitu tempat penari melakukan gerak dalam 
wujud yang sebenarnya, ruang yang digunakan oleh penari saat petunjukan dilakukan.

Hal-hal yang berkaitan dengan ruang baik ruang yang diciptakan oleh penari maupun ruang pentas meliputi garis, volume, arah, level, arah hadap tubuh, dan fokus pandang.

\section{1) Garis}

Garis-garis dalam gerak dapat menimbulkan berbagai macam kesan. Desain pada garis dapat dibedakan menjadi dua, yaitu: garis lurus, yang memberikan kesan sederhana dan kuat. Garis lengkung memberikan kesan yang lembut tetapi juga lemah. Garis mendatar memberikan kesan ketenangan dan keseimbangan. Garis melingkar atau lengkung memberikan kesan manis, sedangkan garis menyilang atau diagonal memberi kesan dinamis (Murgiyanto, 1986: 25).

\section{2) Volume}

Desain tiga dimensi memiliki panjang, lebar, dan tinggi atau kedalaman, yang menghasilkan apa yang dikenal sebagai volume atau isi keruangan yang berhubungan dengan besar kecilnya jangkauan gerak tari (Murgiyanto, 1986: 27).

\section{3) Arah}

Arah merupakan aspek ruang yang mempengaruhi efek estetis ketika bergerak melewati ruang selama tarian itu berlangsung, sehingga ditemukan polapola dan sering dipahami sebagai pola lantai (Hadi, 1996: 13). Arah gerak dapat dilakukan kedepan, kebelakang, kesamping kanan-kiri, diagonal, melingkar, dan sebagainya (Murgiyanto, 2004: 55). 


\section{4) Level}

Level merupakan hubungan dengan tinggi rendahnya penari pada saat melakukan gerakan. Ketinggian maksimal yang dapat dilakukan penari adalah pada saat melompat ke udara dan kerendahan maksimal yang dapat dilakukan penari yaitu pada saat merebahkan diri ke lantai (Murgiyanto, 2004: 55).

Analisis arah dan level harus dibedakan apakah yang dianalisis itu gerak atau penyangga. Gerak (gesture) biasanya digambarkan sebagai gerak yang menuju kesatu tempat atau satu tujuan, sedangkan langkah adalah gerak yang meninggalkan satu tempat penyangga ke tempat penyangga lainnya (Soedarsono, 1978: 15). Posisi kaki penyangga, laban membedakan tiga level penyangga, yaitu: level rendah, level tengah, dan level tinggi. Level rendah adalah level kaki penyangga dalam posisi merendah (mendhak), yaitu tungkak ditekuk pada lutut dan kaki menapak seluruhnya. Level tengah adalah level kaki penyangga dalam keadaan biasa, yaitu tungkai lurus dan kaki menapak seluruhnya. level tinggi adalah level kaki penyangga dengan posisi berjengket (jinjit) yaitu tungkai lurus dan kaki berjengket (Soedarsono, 1978: 16).

5) Arah Hadap Tubuh

Arah hadap tubuh dapat dilakukan oleh tubuh penari misalnya ke depan, ke samping, ke belakang, ke atas, ke bawah dan sebagainya (Murgiyanto, 2004: $55)$.

6) Fokus Pandang

Fokus pandang merupakan sudut pandang suatu perspektif penonton yang diperlukan dalam melakukan tarian. Fokus pandang ditujukan kepada penari yang 
menjadi pusat perhatian bagi penonton, misalnya di pertunjukan tari ada satu penari itu akan menjadi pusat perhatian bagi penonton.

\section{Waktu}

Waktu merupakan elemen yang sangat penting karena tanpa adanya waktu bagi penari untuk menyajikan suatu tarian, suatu bentuk tarian tidak akan terwujud. Waktu bagi penari juga merupakan kesempatan untuk berlatih menari, termasuk mengadakan gladi bersih. Berlatih bagi penari ini dapat meningkatkan kualitas tarian sehingga dalam penyajiannya akan terlihat matang dan memuaskan (Rianawati, 2014: 6).

\subsubsection{Pelaku/Pemain}

Semua jenis seni pertunjukan memerlukan penyaji sebagai pelaku atau seniman yang terlibat langsung maupun tidak langsung untuk mengetengahkan atau menyajikan bentuk pertunjukan. Beberapa seni pertunjukan tertentu ada yang hanya melibatkan pelaku laki-laki saja, atau pelaku perempuan saja, dana tau menampilkan pelaku laki-laki bersamaan dengan pelaku perempuan (Cahyono, 2000: 64).

\subsubsection{Iringan}

Musik dan tari merupakan pasangan yang tidak dapat dipisahkan satu dengan yang lainnya. Keduanya berasal dari sumber yang sama, yaitu dorongan atau naluri ritmis. Keberadaan musik di dalam tari mempunyai tiga aspek dasar yang erat kaitannya dengan tubuh dan kepribadian manusia, yaitu melodi, ritme (ritme metrikal), dan dramatik. Menurut Jazuli (1994:10-12) dalam tari, fungsi 
musik dapat dikelompokkan menjadi tiga, yaitu sebagai pengiring tari, sebagai pemberi suasana tari, sebagai ilustrasi.

1) Sebagai Pengiring Tari

Musik hanya untuk mengiringi atau menunjang penampilan tari, sehingga tak banyak ikut menentukan isi tarinya. Namun demikian, tidak berarti musik kurang mendapatkan perhatian yang serius. Pada dasarnya musik merupakan bagian yang tak terpisahkan (menyatu) dari tari.

2) Sebagai Pemberi Suasana Tari

Musik sangat cocok dipergunakan untuk dramatari, meskipun tidak menutup kemungkinan untuk yang bukan dramatari. Sebab didalam dramatari banyak terdapat pembagian adegan-adegan ataubabak-babak pada alur cerita yang akan dipertunjukan.

3) Sebagai Ilustrasi atau Pengantar Tari

Tari yang menggunakan musik baik sebagai pengiring atau pemberi suasana pada saat-saat tertentu saja, tergantung kebutuhan garapan tari. Musik diperlukan hanya pada bagian-bagian tertentu dari keseluruhan sajian tari, bisa hanya berupa pengantar sebelum tari disajikan, bisa hanya bagian depan dari keseluruhan tari, atau hanya bagian tengah dari keseluruhan sajian tari.

\subsubsection{Rias}

Bagi seorang penari, rias merupakan hal yang sangat penting. Rias juga merupakan hal yang paling peka di hadapan penonton, karena penonton biasanya sebelum menikmati tarian selalu memperhatikan wajah penarinya, baik untuk mengetahui tokoh/peran yang sedang dibawakan maupun untuk mengetahui siapa 
penarinya. Fungsi rias antara lain adalah untuk mengubah karakter pribadi menjadi karakter tokoh yang sedang dibawakan, untuk memperkuat ekspresi, dan untuk menambah daya tarik penampilan (Jazuli, 2008: 23).

Rias dalam kesenian tradisional kerakyatan sangat sederhana. Alasannya oleh karena para penonton yang sekalipun berniat untuk ngibing, tidak memakai pakaian tarinya, atau memulas mukanya dengan make-up yang berwarna-warna (Sedyawati, 1986: 171).

\subsubsection{Busana}

Semula pakaian yang dikenakan oleh para penari adalah pakaian seharihari. Dalam perkembangannya, pakaian tari telah disesuaikan dengan kebutuhan tarinya. Fungsi busana tari adalah untuk mendukung tema atau isi tari,dan untuk memperjelas peran-peran dalam suatu sajian tari. Busana tari yang baik bukan hanya sekedar untuk menutup tubuh semata, melainkan juga harus dapat mendukung desain ruang pada saat penari sedang menari (Jazuli, 2008: 20)

Selanjutnya Jazuli (2008: 21) menambahkan bahwa dalam tradisi tari, busana tari sering mencerminkan identitas (ciri khas) suatu daerah yang sekaligus merujuk pada tari itu berasal. Demikian pula di dalam pemakaian warna busana, tidak jarang suatu daerah tertentu senang dengan warna yang gemerlap atau menyolok, sedangkan di daerah lain lebih berselera dengan warna-warna lembut atau kalem. Semua itu tidak terlepas dari latar belakang budaya atau pandangan filosofi dari masing-masing daerah. 


\subsubsection{Properti dan Sesaji}

Properti berperan serta berfungsi sebagai sesaji bukan hanya benda-benda atau barang-barang yang dipersembahkan dan sesudahnya dapat disantap bersama komunitas sebuah peristiwa pertunjukan. Simbol-simbol properti atau sesaji diharapkan dapat terwadahi berbagai keinginan yang hendak diutarakan. (Kusmayati, 2000: 96).

Sarana dan prasarana dalam sebuah pertunjukan merupakan perlengkapan untuk memberikan kenikmatan dan kenyamanan penontonnya serta untuk menunjang kualitas pertunjukan. Sarana dan prasarana yang ideal bagi sebuah pertunjukan tari adalah bila gedung pertunjukan telah dilengkapi dengan peralatan yang menunjang penyelenggaraan pertunjukan, khususnya tata lampu (lighting) dan tata suara (sound sistem). Tata lampu dan tata suara sebagai unsur pelengkap sajian tari berfungsi membantu kesuksesan pergelaran (Jazuli, 2008: 28-29).

Penataan lampu terdapat warna-warna cahaya yang sangat penting untuk diperhatikan, terutama efeknya yang ditimbulkan terhadap objek lain (busana atau perlengkapan lain). Di sisni pengetahuan tentang efek-efek warna cahaya menjadi sangat penting dan perlu dimanfaatkan secara maksimal (Jazuli, 2008: 30).

\subsubsection{Tata Pentas}

Indonesia dapat mengenal bentuk-bentuk tempat pertunjukan (pentas), seperti di lapangan terbuka, di pendapa, dan pemanggungan (staging). Pertunjukan tari tradisional di lingkungan rakyat sering dipergelarkan di lapangan terbuka. Di kalangan bangsawan Jawa, pertunjukan kesenian sering diadakan di 
pendapa, yaitu suatu bangunan yang berbentuk joglo dan bertiang pokok empat, tanpa penutup pada sisi-sisinya (Jazuli, 2008: 25).

Pemanggungan (staging) merupakan istilah yang berasal dari luar negara kita, tetapi istilah tersebut nampaknya telah memasyarakat pada masa penjajahan Belanda. Bentuk pemanggungan ada bermacam-macam. Bentuk procenium yakni penonton hanya dapat melihat dari sisi depan saja; bentuk tapal kuda yaitu pentas yang bentuknya menyerupai tapal kuda, para penonton bisa melihat dari tiga sisi yaitu sisi depan, sisi samping kiri, sisi samping kanan; bentuk pendapa, para penontonnya seperti halnya bentuk tapal kuda, perbedaannya bangunan pendapa lebih tinggi daripada pentas tapal kuda (sama rata dengan tanah) (Jazuli, 2008: 25).

\subsubsection{Penonton}

Menurut Kamus Besar Bahasa Indonesia (2005: 1085) menerangkan bahwa penonton merupakan orang yang menonton pertunjukan dan orang yang hanya melihat (tidak campur, bekerja, dsb). Penonton melihat seni pertunjukan sebagai apresiasi.

\subsubsection{Kesenian Tradisional Kerakyatan}

Tradisional adalah segala sesuatu yang sesuai dengan tradisi, sesuai dengan kerangka pola-pola bentuk maupun penerapan yang selalu berulang-ulang dan juga kuno, atau sesuatu yang sifatnya luhur sebagai warisan nenek moyang (Sedyawati, 1981: 48). Kesenian adalah salah satu unsur yang menyangga kebudayaan. Kesenian berkembang menurut kondisi dari kebudayaan itu (Kayam, 1981: 15). 
Kesenian tidak pernah berdiri lepas dari masyarakat. Sebagai salah satu bagian yang penting dari kebudayaan, kesenian adalah ungkapan kreatifitas dari kebudayaan itu sendiri. Kesenian tradisional tumbuh dan berkembang dan mengandung sifat-sifat dan ciri khas dari masyarakat yang tradisional (Kayam, 1981: 59-70) hal ini dipertegas oleh Soedarsono (1976: 9) bahwa kesenian tradisional adalah kesenian yang telah mengalami perjalanan lama yang selalu bertumpu pada pola tradisi yang ada.

Menurut Umar Kayam (1981: 61) kesenian tradisional mempunyai ciri-ciri khusus sebagai berikut:

1) Kesenian tradisional mempunyai jangkauan terbatas pada lingkungan kultur yang menjaga.

2) Kesenian tradisional merupakan cerminan dari satu keharusan yang berkembang sangat perlahan-lahan karena dinamika pendukungnya.

3) Kesenian tradisional bukan merupakan hasil kreativitas individu-individu tetapi tercipta secara anonim bersama dengan sifat aktivitas masyarakat pendukungnya.

Lanjut menurut Sedyawati (1986: 169) bahwa ciri-ciri kesenian tradisional kerakyatan yaitu:

1) Fungsi sosial,

2) Ditarikan penari bersama,

3) Menuntut spontanitas atau respon,

4) Bentuk geraknya sederhana,

5) Tata rias dan tata busana pada umumnya sederhana, 
6) Irama iringan dinamis dan cenderung cepat,

7) Jarang membawa cerita lakon,

8) Jangka waktu pertunjukan tergantung dari gairah penari yang tergugah,

9) Sifat kesenian tradisional kerakyatan sering homoristis,

10) Tempat pementasan berbentuk arena,

11) Bertemakan kehidupan masyarakat.

Menurut Jazuli (2008: 71) kesenian tradisional adalah kesenian yang lahir, tumbuh, berkembang dalam suatu masyarakat yang kemudian diturunkan atau diwariskan secara terus-menerus dari generasi ke generasi. Lebih lanjut Jazuli (2008: 72) menjelaskan bahwa seni tradisional merupakan ekspresi masyarakat yang hidup di luar tembok istana, yang berfungsi sebagai sarana upacara dan hiburan. Seni tradisional sebagai sarana upacara dapat dibedakan menjadi tiga, yaitu upacara pernikahan, upacara adat yang berkaitan dengan peristiwa alamiah dan upacara adat yang berkaitan dengan peristiwa kehidupan manusia. Berdasarkan uraian diatas, dapat disimpulkan bahwa kesenian tradisional adalah kesenian yang hidup dan berkembang dikalangan masyarakat biasa yang mencerminkan identitas daerahnya.

\subsubsection{Pelestarian Seni Tradisi}

Pelestarian adalah pengelolaan sumberdaya alam yang menjamin pemanfaatannya secara bijaksana dan menjamin kesinambungan persediaannya dengan tetap memelihara dan meningkatkan kualitas nilai dan keanekaragaman. Upaya pelestarian lingkungan dengan cara konservasi. Konsep konservasi adalah konsep proses pengelolaan suatu tempat atau ruang atau obyek agar makna 
kultural yang terkandung didalamnya terpelihara sesuai dengan kondisi dan situasi lokal maupun upaya pengembangan untuk pemanfaatan lebih lanjut (Tim MKU PLH, 2014: 38).

Strategi pelestarian warisan budaya berkenaan dengan dua aspek, yaitu (1) kelembagaan, dan (2) sumber daya manusia. Disamping itu harus pula ditetapkan lebih dahulu, apa tujuan dari pelestarian warisan budaya itu. Pelestarian mempunyai makna bahwa didalamnya terdapat dua aspek yaitu pemertahanan dan dinamika (Sedyawati, 2008: 208) .

Pelestarian budaya yang dirumuskan dalam draf RUU tentang Kebudayaan (1999: 77) dijelaskan bahwa pelestarian budaya berarti pelestarian terhadap eksistensi suatu kebudayaan dan bukan berarti membekukan kebudayaan didalam bentuk-bentuknya yang sudah pernah dikenal saja. Pelestarian dilihat sebagai suatu yang terdiri dari tiga aspek, yaitu (1) perlindungan, (2) pengembangan, dan (3) pemanfaatan (Sedyawati, 2008: 152). Selanjutnya tiga tujuan pemanfaatan budaya yang dapat diidentifikasikan, yaitu, (1) pendidikan (baik terstruktur maupun tidak terstruktur, formal maupun non formal atau pendidikan masyarakat), (2) industri, dalam hal ini untuk menghasilkan produk kemasan-kemasan industri budaya, (3) pariwisata, baik untuk wisatawan umum maupun wisatawan minat khusus (Sedyawati, 2008: 152).

FX. Rahyono (2015: 33) menambahkan bahwa pelestarian dan pengembangan kebudayaan sebaiknya dilakukan dengan cara memaknai dan mengemas kembali nilai-nilai budaya dalam wujudnya yang baru sesuai dengan tuntutan dunia kehidupan yang terus-menerus berubah. 
Tindakan-tindakan atau upaya pelestarian yang dapat ditempuh yaitu: (1) pendokumentasian secermat mungkin dengan menggunakan berbagai media yang sesuai; hasil dokumentasi ini selanjutnya dapat menjadi sumber acuan, tentunya apabila disimpan di tempat yang aman dan diregistrasi secara sistematis dengan kemungkinan penelusuran yang mudah, (2) pembahasan dalam rangka penyadaran, khususnya mengenai nilai-nilai budaya, norma, dan estetika, (3) pengadaan acara penampilan yang memungkinkan orang "mengalami" dan "menghayati". Tanpa ketiga tindakan tersebut maka pelestarian mungkin tidak akan terjadi dengan sendirinya secara alamiah (Sedyawati, 2008: 280). Seni tradisi adalah seni yang penyampaiannya dari generasi ke generasi berikutnya atau dari guru ke murid dilakukan secara lisan (Soedarsono 2003: 108).

Menurut Heni Gustini Nuraeni dkk (2012: 92) bentuk upaya pelestarian kesenian daerah bisa dengan cara-cara sebagai berikut:

(1) Pemerintah memberikan fasilitas atau subsidi secara rutin dalam jumlah tertentu kepada perkumpulan-perkumpulan kesenian yang memerlukannya dan cukup bermutu. Bantuan ini dimaksudkan untuk meningkatkan prestasi para pengelola kesenian dalam penciptaan karya seni dan untuk merangsang inovasi ke arah pengembangan kesenian nasional, yang meliputi seni tari, seni musik, seni drama, seni busana, seni rupa, seni bangunan (arsitektur), dan sebagainya.

(2) Semua pemangku kepentingan (stake holders : pemerintah, seniman/seniwati, pengelola kesenian, masyarakat peminat seni, dan media masa) dapat 
melakukan diseminasi karya-karya seni melalui media elektronik, media cetak, dan berbagai pertunjukan atau pameran.

(3) Semua pemangku kepentingan (stake holders) harus giat untuk meningkatkan gerakan apresiasi kesenian, misalnya melalui kegiatan ekstrakurikuler di sekolah dan kampus, mengadakan berbagai lomba kesenian di sekolah, kampus, dan lingkup kelurahan, kecamatan, dan seterusnya, pada acara-acara tertentu.

(4) Semua pemangku kepentingan dapat melakukan gerakan revitalisasi dan pembudayaan kembali kesenian yang kini sudah hampir punah atau sudah punah, contohnya : pertunjukan wayang orang, wayang kulit, ketoprak, ludruk, seni karawitan, musik kulintang, musik angklung, kesenian gambang semarang, seni bangunan (arsitektur) lokal, dan sebagainya.

Upaya pelestarian diarahkan untuk membuat seni tradisi tetap ada dalam masyarakat setempat. Salah satu cara agar pelestarian seni tradisi tetap ada adalah dengan mengenalkan kepada generasi muda. Dalam upaya pelestarian tetap harus ada pembinaan terhadap kesenian daerah. Pembinaan dilakukan agar ada proses pengembangan pada seni tradisi tersebut. Pengembangan diadakan agar seni tradisi tersebut tetap hidup dalam masa sekarang ini. Usaha pelestarian seni tradisi merupakan kegiatan dalam mempertahankan seni tradisi dalam masyarakat dengan melakukan berbagai penyesuaian. Usaha pelestarian memegang peranan yang penting, karena merupakan sumber untuk masa yang akan datang. Upaya pelestarian seni tradisi merupakan upaya nyata, yang bertolak dari masa lampau dan berorientasi pada masa datang. 


\subsubsection{Kesenian Sintren Dangdut}

Menurut Etimologi kata Sintren terdiri dari kata si dan tren. Kata tren sendiri berasal dari kata putri dan akhiran an. Kemudian digabung menjadi kata si- putri-an. Penggabungan dua huruf hidup (dalam hal ini huruf $i$ dan $a$ ) berubah bunyinya menjadi e sehingga kata si-putri-an berubah menjadi kata siputren yang disingkat dalam bahasa jawa digarba menjadi si- tren mendapat sisipan $n$ jadilah kata sintren (wikipedia, 16 Maret 2013).

Menurut Proyek Inventarisasi Kebudayaan Daerah Jawa Tengah Khususnya Kesenian Tradisional (1991: 168), sintren adalah suatu bentuk pertunjukan dimana seorang gadis menari-nari dalam keadaan tidak sadar dengan diiringi seni suara baik berasal dari suara manusia (vokal) maupun suara gamelan. Dari orientasi ini, dapat dipakai sebagai dasar dalam mengupas arti kata "sintren" yang dipakai sebagai nama kesenian ini. Kata "sintren" disamping dimaksudkan sebagai nama bagi seorang gadis remaja dan masih suci yang menjadi pelaku utama dari suatu jenis keseniannya itu sendiri secara keseluruhan, yaitu seni sintren.

Musik dangdut juga mempunyai pengertian yang sama dengan pengertian musik yaitu pernyataan hati seseorang yang diungkapkan dalam bentuk bunyi yang teratur melalui unsure irama, melody, harmoni, struktur atau bentuk lagu, dan ekspresi sebagai satu kesatuan yang berjalan selaras dan seimbang. Musik dangdut mempunyai cirri yang sangat khas. Salah satu ciri khas musik dangdut adalah irama musiknya yang ditandai dengan permainan gendang kembar yang menghasilkan bunyi "dang" dan "dut". Diperkirakan irama musik ini merupakan 
perpaduan irama melayu deli, musik kasidah, dan irama tabla dari India (Suharto, 1995: 12).

Musik dangdut menerima berbagai unsur musik lain secara mudah, bangunan sebagian besar musik dangdut sangat konservatif. Musik dangdut mulai lebih dikenal pada tahun 1969-an. Dengan munculnya seorang bintang, Ellya Khadam dengan lagu hitsnya " Boneka Cantik dari India “, yang didukung dengan munculnya bintang-bintang lainnya dengan ciptaan lagu dalam irama yang sejenis (Slamet Haryono, 2002: 23).

Dangdut adalah aliran musik yang sudah tidak asing bagi masyarakat Indonesia, karena sangat merakyat bagi bangsa Indonesia sejak jaman berdirinya negara Indonesia. Musik dangdut berakar dari musik melayu yang mulai berkembang pada tahun 1940. Irama melayu sangat kental dengan unsur aliran musik dari India dan gabungan dengan irama musik dari Arab. Unsur tabuhan gendang yang merupakan unsur musik India digabungkan dengan unsur cengkok penyanyi dan harmonisasi dengan irama musiknya merupakan suatu ciri khas irama melayu adalah awal mutasi irama melayu ke dangdut (Alit Sri Mulyani, 24 mei 2012).

Berdasarkan pengertian Sintren dengan Dangdut dapat disimpulkan bahwa kesenian Sintren Dangdut merupakan kesenian yang menggabungkan antara Sintren dengan Dangdut untuk memikat daya tarik penonton agar kesenian Sintren Dangdut tidak punah atau dilupakan. Kesenian Sintren Dangdut tidak mengubah ciri khas Sintren yaitu pelaku utama Sintren seorang gadis yang masih suci (perawan) dirasuki oleh roh/dewi-dewi kemudian intrance. Pertunjukan kesenian 
Sintren itu diselingi oleh musik dangdut yang menarik penonton karena minat masyarakat yang menyukai musik dangdut (wawancara Bapak Dalang, April 2016).

\subsubsection{Faktor Pendukung dan Penghambat Perubahan Bentuk Pertunjukan}

Lingkungan yang dihadapi oleh masyarakat yang terus-menerus sama akan tetapi terus berubah baik dalam kuantitas maupun kualitas. Kondisi semacam itu berpengaruh juga pada kesenian tradisional termasuk kesenian Sintren. Perubahan sosial merupakan bagian dari perubahan budaya. Kesenian termasuk dalam perubahan kebudayaan, dan dalam perubahan tersebut terdapat faktor-faktor yang menunjang. Perubahan sosial adalah segala perubahan pada lembaga-lembaga di dalam suatu masyarakat, yang mempengaruhi sistem sosialnya, termasuk di dalamnya nilai- nilai, sikap-sikap, dan pola-pola perilaku antara kelompokkelompok dalam masyarakat (Soekanto, 1990: 338-339).

Suatu hal yang tidak dapat disangkal dan dihindari perubahan alam pikiran dan pandangan hidup manusia mengakibatkan terjadinya perubahan atau perkembangan tata hidup masyarakat pada jamannya. Faktor-faktor yang mendorong bagi individu dalam suatu masyarakat untuk memulai dan mengembangkan penemuan-penemuan baru adalah: (1) kesadaran para individu akan kekurangan dalam kebudayaan; (2) mutu dari keahlian dalam suatu kebudayaan;(3) sistem perangsang bagi aktivitas mencipta dalam masyarakat (Koentjaraningrat, 2009: 212).

Dalam tiap masyarakat tentu ada individu-individu yang sadar akan adanya berbagai kekurangan dalam kebudayaan mereka. Dari kategori individu- 
individu tersebut terakhir inilah antara lain muncul para pencipta dari penemuanpenemuan baru, baik yang bersifat discovery maupun yang bersifat invention. Menemukan suatu hal yang baru memerlukan suatu daya kreatif dan usaha yang besar, tetapi menyebarkan suatu hal baru yang memerlukan daya dan usaha lebih besar lagi (Koentjaraningrat, 2009: 212).

Faktor-faktor yang menyebabkan perubahan sosial dan kebudayaan menurut Soekanto (1990: 390), yaitu:

1. Sebab-sebab yang bersumber dalam masyarakat itu sendiri (faktor internal):
a. bertambah atau berkurangnya penduduk,
b. penemuan-penemuan baru,
c. pertentangan-pertentangan dalam masyarakat,
d. terjadinya pemberontakan atau revolusi di dalam tubuh masyarakat itu sendiri.
2. Sebab-sebab yang berasal dari luar masyarakat (faktor eksternal):
a. sebab-sebab yang berasal dari lingkungan fisik yang ada di sekitar manusia,
b. peperangan dengan negara lain,
c. pengaruh kebudayaan masyarakat lain.

Faktor-faktor yang mempengaruhi jalannya proses perubahan menurut Soekanto (1990: 390-391) adalah:

1. Faktor-faktor yang mendorong jalannya proses perubahan:
a. kontak dengan kebudayaan lain,
b. sistem pendidikan yang maju,
c. sikap menghargai hasil karya seseorang dan keinginan-keinginan untuk maju
d. toleransi terhadap perbuatan-perbuatan menyimpang, 
e. sistem lapisan masyarakat yang terbuka,

f. penduduk yang heterogen,

g. ketidakpuasan masyarakat terhadap bidang-bidang kehidupan tertentu,

h. orientasi ke muka,

i. nilai meningkatkan taraf hidup.

2. Faktor-faktor yang menghambat terjadinya perubahan:

a. kurangnya hubungan dengan masyarakat-masyarakat lain,

b. perkembangan ilmu pengetahuan yang terlambat,

c. sikap masyarakat yang tradisionalistis,

d. adanya kepentingan-kepentingan yang telah tertanam dengan kuat atau vested interest,

e. rasa takut akan terjadinya kegoyahan pada integrasi kebudayaan,

f. prasangka terhadap hal-hal yang baru/asing,

g. hambatan ideologis,

h. kebiasaan,

i. nilai pasrah.

Berdasarkan uraian diatas dapat disimpulkan, kesenian selalu mengalami perkembangan dari waktu ke waktu, yang akan mengakibatkan suatu perubahan, karena pada dasarnya berubah adalah sifat utama dari sebuah kesenian. Perubahan dapat terjadi karena adanya faktor internal dan faktor eksternal yang mempengaruhi diri pelaku itu sendiri oleh masyarakat. Perubahan disebabkan oleh masyarakat, sosial, ilmu pengetahuan maupun teknologi. Seperti kesenian Sintren ini yang ada perubahan sedikit ditambah dengan dangdut karena ada faktor 
internal maupun eksternal yang mempengaruhinya. Jadi kesenian Sintren berubah bentuk menjadi kesenian Sintren Dangdut karena ada faktor-faktor yang mendukung dan menghambatnya. 


\subsection{Kerangka Berfikir}

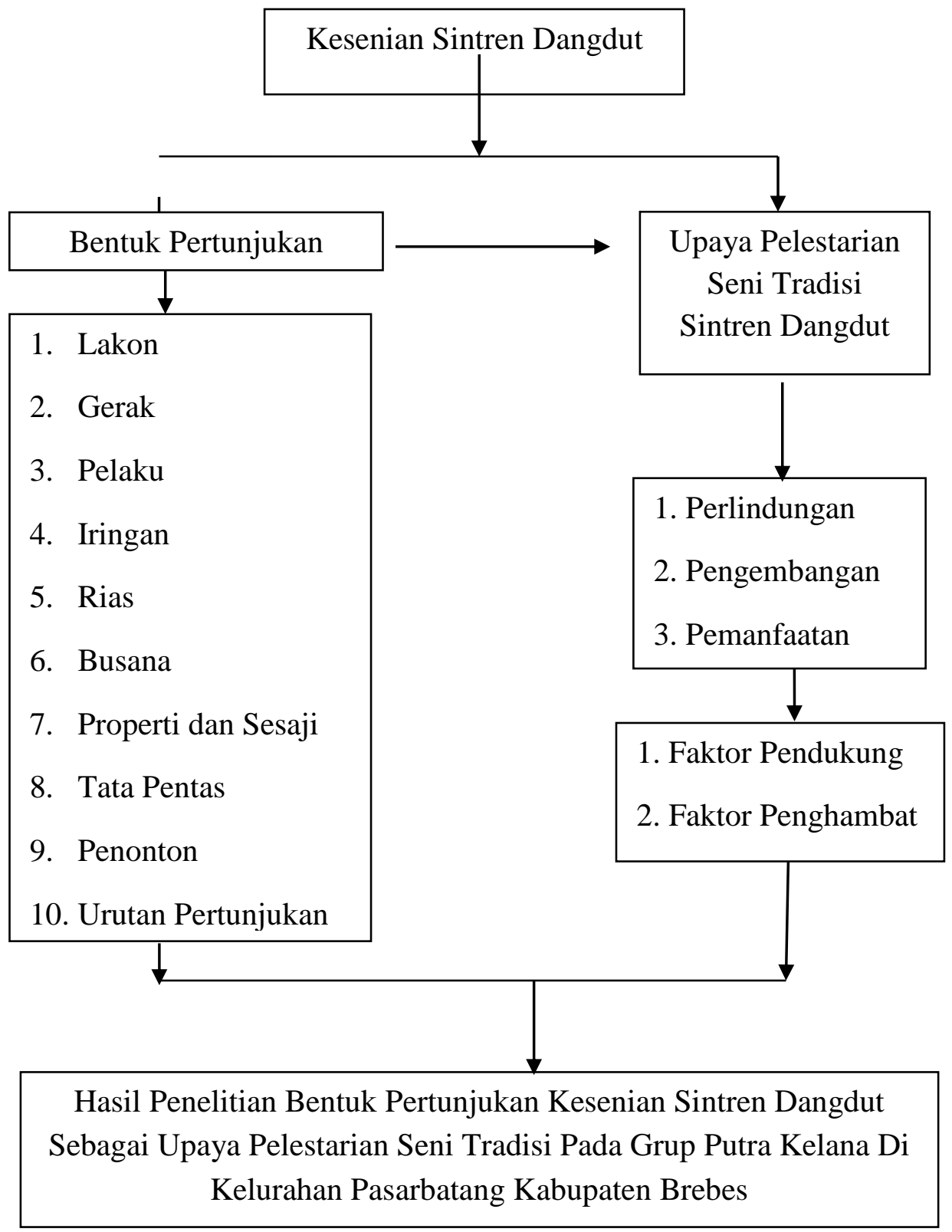

Bagan. 2.1 Kerangka Berfikir

(Amalia Mega Hardiyanti 2016)

Berdasarkan bagan kerangka berfikir diatas, peneliti dapat menguraikan bahwa pertunjukan kesenian Sintren Dangdut pada Grup Putra Kelana di Kelurahan pasarbatang Kabupaten Brebes sering dipentaskan di berbagai acara, 
seperti bersih desa, sedekah bumi, pemberian nama pada bayi baru lahir, hajatan, khitanan, dan syukuran hari jadi Kabupaten Brebes. Penelitian mengenai Bentuk Pertunjukan Kesenian Sintren Dangdut Sebagai Upaya Pelestarian Seni Tradisi pada Grup Putra Kelana di Kelurahan Pasarbatang Kabupaten Brebes dilihat dari dua aspek yaitu bentuk pertunjukan dan upaya pelestarian seni tradisi Sintren Dangdut.

Pada bentuk pertunjukan peneliti mengambil dua konsep dari Soedarsono dengan Kusmayati yang digabungkan menjadi 10 bagian yang meliputi Lakon, Gerak, Pelaku, Iringan, Tata Rias, Tata Busana, Tata Pentas, Properti, Penonton, dan Urutan Pertunjukan kesenian Sintren Dangdut. Selain dari aspek bentuk pertunjukan, kesenian Sintren Dangdut ini membahas tentang upaya pelestarian seni tradisi Sintren Dangdut. Dalam upaya pelestarian seni tradisi Sintren Dangdut, ada perubahan bentuk kebudayaan yang berpengaruh pada perlindungan, pengembangan dan pemanfaatan kesenian Sintren Dangdut tersebut. Kemudian pada kesenian Sintren Dangdut terdapat faktor-faktor yang mempengaruhinya yaitu faktor pendukung dan penghambat kesenian Sintren Dangdut. 


\section{BAB 3}

\section{METODE PENELITIAN}

Penelitian adalah suatu proses penyelidikan dari suatu disiplin yang relevan untuk kegiatan tersebut. Proses yang pada dasarnya bersifat umum dan baku, tetapi harus dikerangkai dan dibiasakan oleh disiplin tertentu dan wilayah perhatian (Tjetjep 2011: 169). Selanjutnya jika penelitian dipandang sebagai sebuah proses, maka pembelajaran tentang penelitian harus dipandang sebagai kegiatan untuk menjawab bagaimana suatu penelitian harus dilaksanakan.

Penelitian selalu membutuhkan suatu metode untuk mendapatkan data yang dibutuhkan agar dapat dipertanggungjawabkan secara ilmiah. Menurut Husaini (2001: 42) metode ialah suatu prosedur atau suatu cara untuk mengetahui sesuatu, yang mempunyai langkah-langkah sistematis, sedangkan metodologi ialah suatu pengkajian dalam mempelajari peraturan-peraturan suatu metode. Jadi, metodologi penelitian ialah suatu pengkajian dalam mempelajari peraturanperaturan yang terdapat dalam penelitian. Secara umum metode penelitian diartikan sebagai cara ilmiah untuk mendapatkan data dengan tujuan dan kegunaan tertentu (Sugiyono 2012: 3). Setelah mendapatkan data, peneliti mengolah menjadi suatu bentuk laporan penelitian atau menjabarkan data yang diperoleh dari lapangan dalam laporan tersebut.

Metode penelitian yang digunakan dalam bentuk pertunjukan Sintren Dangdut sebagai upaya pelestarian seni tradisi pada Grup Putra Kelana ini adalah metode penelitian kualitatif yang bersifat deskriptif. Penelitian ini berlandaskan 
pada filsafat postpositivisme, digunakan untuk meneliti pada kondisi obyek yang alamiah, teknik pengumpulan data dengan trianggulasi (gabungan), analisis data bersifat induktif/kualitatif, dan hasil penelitian kualitatif lebih menekankan makna dari pada generalisasi (Sugiyono 2012: 15). Penelitian dilakukan pada objek yang alamiah yaitu pada kesenian Sintren Dangdut. Pada kesenian Sintren Dangdut telah berkembang apa adanya, tidak diadakan atau dimanipulasi oleh peneliti dan kehadiran peneliti tidak mempengaruhi dinamika pada kesenian Sintren Dangdut tersebut.

\subsection{Pendekatan Penelitian}

Pendekatan penelitian pada bentuk pertunjukan Sintren Dangdut sebagai upaya pelestarian seni tradisi pada grup Putra Kelana ini mengambil pendekatan naturalistik dan fenomenologi. Menurut Lincoln dan Guba (1985: 39) lebih suka menggunakan istilah naturalistik inquiry oleh karena ciri yang meonjol dari penelitian ini adalah cara pengamatan dan pengumpulan datanya dilakukan dalam latar/setting alamiah, artinya tanpa memanipulasi subjek yang diteliti (sebagaimana adanya natur). Kondisi yang alamiah dalam penelitian ini adalah peneliti tidak saja mengamati ketika sebuah grup kesenian Sintren Dangdut dan masyarakat bertinteraksi pada pertunjukan Sintren Dangdut tetapi juga di beberapa tempat lain yang biasanya dijadikan tempat berkumpul para pelaku pertunjukan Sintren Dangdut misalnya di kediaman pimpinan grup Sintren Dangdut dan lingkungan sekitar pertunjukan kesenian Sintren Dangdut. Penelitian ini berorientasi pada proses artinya proses dalam penelitian ini adalah adanya kesenian Sintren pada Kelurahan Pasarbatang dan kesenian itu telah berkembang 
dengan perubahan menjadi Sintren Dangdut karena realita yang ada bahwa masyarakat lebih suka diperdengarkan musik dangdut. Jadi penelitian ini apa adanya, dan tidak dimanipulasi dalam proses bentuk pertunjukan kesenian Sintren Dangdut sebagai upaya pelestarian seni tradisi. Di samping wawancara, peneliti mengadakan pemetaan dan peneliti merekam apa yang terjadi pada realitas budaya pada kesenian Sintren Dangdut.

Peneliti juga mengambil pendekatan fenomenologi karena menurut Suwardi (2003: 42) pendekatan ini lebih menekankan rasionalisme dan realitas budaya yang ada. Pendekatan ini berusaha memahami budaya lewat pandangan pemilik budaya atau pelakunya. Artinya dalam penelitian ini, kesenian Sintren yang sudah lama lahir di Kelurahan Pasarbatang berkembang menjadi kesenian Sintren Dangdut karena realitas budaya yang ada pada masyarakat setempat lebih menyukai musik dangdut, tetapi kesenian ini juga tidak mengabaikan rasionalisme yang ada pada Sintren tersebut. Kesenian Sintren Dangdut berkembang sebagai upaya pelestarian seni tradisi dan itu menjadi suatu fenomena atau gejala yang timbul akibat minat masyarakat. Keterlibatan subjek peneliti di lapangan dan penghayatan fenomena kesenian Sintren Dangdut yang dialami menjadi salah satu ciri utama.

Oleh karena itu, penelitian ini menggunakan metode penelitian kualitatif yang bersifat deskriptif, kemudian menggunakan pendekatan naturalistik dan fenomenologi dengan menggambarkan atau mengkaji bentuk pertunjukan kesenian Sintren Dangdut sebagai upaya pelestarian seni tradisi pada grup Putra Kelana, kemudian gambaran tersebut dianalisis dan diinterpretasikan oleh peneliti. 


\subsection{Lokasi dan Sasaran Penelitian}

\subsubsection{Lokasi Penelitian}

Lokasi penelitian ini adalah di Kelurahan Pasarbatang Kabupaten Brebes yang batas wilayahnya adalah: sebelah Utara Desa Sigambir, sebelah Selatan Kelurahan Brebes, sebelah Barat Desa Pesantunan, sebelah Timur Kelurahan Limbangan Kulon. Kelurahan Pasarbatang juga termasuk dalam klasifikasi kelurahan dalam perkotaan. Peneliti memilih lokasi ini karena di tempat tersebut kesenian Sintren Dangdut pertama kali muncul dan berkembang.

\subsubsection{Sasaran Penelitian}

Sasaran penelitian ini sesuai dengan permasalahan penelitian yang pertama adalah untuk mengetahui bentuk pertunjukan kesenian Sintren Dangdut grup Putra Kelana di Kelurahan Pasarbatang Kabupaten Brebes yang meliputi: (1) Pelaku pertunjukan Sintren Dangdut. (2) perlengkapan pertunjukan Sintren Dangdut. (3) urutan pertunjukan Sintren Dangdut.

Kedua untuk mengetahui upaya pelestarian seni tradisi dalam bentuk pertunjukan Sintren Dangdut pada grup Putra Kelana di Kelurahan Pasarbatang Kabupaten Brebes yang meliputi apa saja upaya-upaya pelestarian seni tradisi yang di pertahankan dan dikembangkan dalam bentuk pertunjukan Sintren Dangdut pada Grup Putra Kelana di Kelurahan Pasarbatang kabupaten Brebes.

Ketiga untuk mengetahui faktor-faktor apakah yang menjadi pendukung dan penghambat bentuk pertunjukan kesenian Sintren Dangdut sebagai upaya 
pelestarian seni tradisi pada grup Putra Kelana di Kelurahan Pasarbatang Kabupaten Brebes.

\subsection{Data dan Sumber Data}

Dalam sub judul data dan sumber data ini akan dibahas mengenai data apa saja yang dibutuhkan dalam penelitian ini. Sumber data merupakan dari mana data-data yang dibutuhkan tersebut diperoleh.

\subsubsection{Data}

Penelitian ini dimaksudkan untuk mengetahui dan mendeskripsikan bentuk pertunjukan kesenian Sintren Dangdut sebagai upaya pelestarian seni tradisi pada Grup Putra Kelana di Kelurahan Pasarbatang Kabupaten Brebes. Oleh karena itu, data yang dibutuhkan dalam penelitian ini adalah (1) data yang berkaitan dengan kondisi penduduk serta lokasi penelitian, (2) data yang berkaitan dengan bentuk pertunjukan kesenian Sintren Dangdut Grup Putra Kelana, (3) data yang berkaitan dengan upaya pelestarian seni tradisi dalam bentuk pertunjukan kesenian Sintren Dangdut Grup Putra Kelana.

Data pertama dari penelitian ini berupa tabel data kependudukan Kelurahan Pasarbatang Kabupaten Brebes yang sudah ada serta gambaran umum lokasi penelitian. Data diperoleh dengan cara peneliti survai secara langsung di Kantor Kelurahan Pasarbatang Kabupaten Brebes kemudian mendapat data tentang monografi Kelurahan Pasarbatang dan data tentang kesenian-kesenian yang ada di Kelurahan Pasarbatang Kabupaten Brebes serta observasi langsung lokasi penelitian pada rumah pimpinan Grup Putra Kelana Bapak Dalang dan mendapat data tentang kesenian Sintren Dangdut.. Data kedua dari penelitian ini 
berupa catatan sejarah kesenian Sintren Dangdut, urutan pertunjukan, ragam gerak, rias dan busana yang digunakan, tembang dan iringan musik, serta perlengkapan pertunjukan. Catatan sejarah Sintren Dangdut diperoleh dengan cara wawancara langsung kepada pimpinan Grup Putra Kelana. Data yang berhubungan dengan pertunjukan seperti urutan pertunjukan, peneliti terjun langsung ke lokasi pertunjukan saat diadakannya pertunjukan Sintren Dangdut. Setelah pertunjukan, peneliti wawancara juga dengan para pemain pertunjukan kesenian Sintren Dangdut. Data ketiga yang dibutuhkan dari penelitian ini yaitu bagaimana upaya pelestarian seni tradisi dalam bentuk pertunjukan kesenian Sintren Dangdut Grup Putra Kelana. Data ini diperoleh dengan cara peneliti mengamati langsung upaya apa saja yang dipertahankan maupun dikembangkan dari bentuk pertunjukan kesenian Sintren Dangdut Grup Putra Kelana.

\subsubsection{Sumber Data}

Sumber data yang digunakan dalam penelitian ini diperoleh dari tempat atau lokasi yang dijadikan sebagai objek penelitian. Lokasi ini adalah Kelurahan Pasarbatang Kabupaten Brebes dengan objek atau sasaran penelitiannya adalah Bentuk Pertunjukan Kesenian Sintren Dangdut sebagai Upaya Pelestarian Seni Tradisi pada Grup Putra kelana. Sumber data yang diperoleh sebagai bahan analisis data dikelompokkan sebagai berikut:

3.3.2.1 Data primer, yaitu data yang didapatkan secara langsung dari responden dan orang-orang yang menjadi informan. Responden penelitian ini adalah para pelaku pertunjukan kesenian Sintren Dangdut yaitu Bapak Dalang selaku pimpinan Grup Putra Kelana, Ibu Musdah selaku Pawang Sintren 
Dangdut, Bapak Amad selaku pemusik Sintren Dangdut, Ibu Firli selaku penyanyi Dangdut pada Sintren Dangdut, Mala selaku pelaku Sintren Dangdut, Ipung selaku pelaku bodhor, Ibu Tarminah selaku sinden pada Sintren Dangdut. Sedangkan yang menjadi informan adalah tokoh masyarakat serta para pelaku pertunjukan kesenian Sintren Dangdut yaitu Mangesthi selaku masyarakat Kelurahan Pasarbatang Kabupaten Brebes. Data primer berupa rekaman dan foto responden dan informan saat wawancara dengan peneliti.

3.3.2.2 Data sekunder, yaitu data yang diperoleh secara tidak langsung dari sumber utama. Data sekunder ini diperoleh dari instansi terkait, Kantor Kelurahan Pasarbatang Kabupaten Brebes, bahan-bahan dari dokumentasi seperti pustaka terkait, buku, jurnal, majalah ilmiah, monografi dan lain-lain. Data sekunder yang didapat pada Kelurahan Pasarbatang adalah data monografi Kelurahan Pasarbatang Kabupaten Brebes, serta koran yang berupa informasi tentang kesenian Sintren Dangdut Grup Putra Kelana.

\subsection{Teknik Pengumpulan Data}

Teknik pengumpulan data merupakan langkah yang paling strategis dalam penelitian, karena tujuan utama dari penelitian adalah mendapatkan data. Tanpa mengetahui teknik pengumpulan data, maka peneliti tidak akan mendapatkan data yang memenuhi standar data yang ditetapkan (Sugiyono 2011: 224).

Sugiyono (2012: 308-309) menambahkan bila dilihat dari sumber datanya, maka pengumpulan data dapat menggunakan sumber primer dan sumber 
sekunder. Sumber primer adalah sumber data yang langsung memberikan data kepada pengumpul data, dan sumber sekunder merupakan sumber yang tidak langsung memberikan data kepada pengumpul data, misalnya lewat orang lain atau lewat dokumen. Metode pengumpulan data yang digunakan dalam penelitian ini meliputi teknik observasi, teknik wawancara, dan teknik dokumentasi.

\subsubsection{Observasi}

Observasi merupakan suatu proses yang kompleks, suatu proses yang tersusun dari berbagai proses biologis dan psikologis. Dua di antara yang terpenting adalah proses-proses pengamatan dan ingatan (Hadi dalam Sugiyono 2012: 203). Sedangkan menurut Arikunto (2010: 265) metode observasi adalah suatu usaha sadar untuk mengumpulkan data yang dilakukan secara sistematis, dengan prosedur yang standar. Untuk mendapatkan informasi yang akurat serta objektif maka peneliti harus memperoleh data yang tepat dan juga harus terjun langsung ke lapangan mengadakan pengamatan langsung terhadap gejala-gelaja nyata pada objek yang diteliti.

Teknik observasi dilakukan dengan cara mengikuti langsung pertunjukan kesenian Sintren Dangdut grup Putra Kelana di Kelurahan Pasarbatang Kabupaten Brebes, dengan melakukan pengamatan dari awal sampai akhir pertunjukan. Selain itu juga meneliti tentang Upaya Pelestarian Seni Tradisi Kesenian Sintren Dangdut. Langkah-langkah observasi dalam penelitian bentuk pertunjukan kesenian Sintren Dangdut Sebagai Upaya Pelestarian Seni Tradisi pada Grup Putra Kelana Di Kelurahan Pasarbatang Kabupaten Brebes yaitu: 
1. Mengamati lingkungan fisik Kelurahan Pasarbatang Kabupaten Brebes. Pengamatan dilakukan untuk mendapatkan informasi tentang letak, kondisi geografis, dan jumlah penduduk Kelurahan Pasarbatang.

2. Mengamati dan mengikuti berlangsungnya pertunjukan kesenian Sintren Dangdut grup Putra Kelana di Kelurahan Pasarbatang Kabupaten Brebes pada saat sedekah bumi dan hajatan. Ada perbedaan dari kedua pertunjukan tersebut, pada saat sedekah bumi dangdut yang dinyanyikan hanya satu lagu saja sebagai selingan agar penikmat kesenian tidak bosan sedangkan pada saat acara hajatan dangdut yang dinyanyikan ada beberapa lagu karena minat penikmat atau penonton lebih ke dangdutnya. Peneliti lebih memfokuskan pada penelitian acara hajatan karena pada acara hajatan perbedaan muncul dari kesenian Sintren pada umumnya dengan kesenian Sintren Dangdut.

3. Mengamati upaya pelestarian seni tradisi melalui bentuk pertunjukan kesenian Sintren Dangdut Grup Putra Kelana Kelurahan Pasarbatang Kabupaten Brebes. Agar mengetahui upaya apa saja yang telah dilakukan grup tersebut, bagaimana perlindungan, pengembangan, dan pemanfaatan upaya pelestarian seni tradisi berjalan dengan baik. Serta mengetahui faktor pendukung dan penghambat upaya pelestarian seni tradisi tersebut.

Pengumpulan data ini, peneliti menggunakan teknik observasi partisipasi pasif. Peneliti melakukan penelitian dengan cermat selama proses latihan dan pementasan kesenian Sintren Dangdut. Proses pengamatan langsung digunakan alat bantu digital recorder dan kamera foto untuk merekam hasil yang diamati. 


\subsubsection{Wawancara}

Wawancara adalah percakapan dengan maksud tertentu agar mendapatkan data. Husaini (2001: 57-58) mengatakan bahwa wawancara ialah tanya jawab lisan antara dua orang atau lebih secara langsung. Pewawancara disebut interviewer sedangkan orang yang diwawancarai disebut interviewee.

Susan (dalam Sugiyono 2012: 318) menambahkan bahwa dengan wawancara, maka peneliti akan mengetahui hal-hal yang lebih mendalam tentang partisipan dalam menginterprestasikan situasi dan fenomena yang terjadi, dimana hal ini tidak bisa ditemukan melalui observasi. Dalam melakukan wawancara, selain harus membawa instrumen sebagai pedoman untuk wawancara, maka pengumpul data juga dapat menggunakan alat bantu seperti tape recorder, gambar,brosur, dan material lain yang dapat membantu pelaksanaan wawancara menjadi lancar (Sugiyono 2012: 195).

Langkah-langkah dalam wawancara dengan narasumber tentang bentuk pertunjukan kesenian Sintren Dangdut sebagai upaya pelestarian seni tradisi pada Grup Putra Kelana di Kelurahan Pasarbatang Kabupaten Brebes sebagai berikut:

1. Mewawancarai Bapak Dalang Wertadiharjo selaku pimpinan Grup Sintren Dangdut Putra Kelana mengenai asal usul, bentuk pertunjukan, dan upaya pelestarian seni tradisi Sintren Dangdut di Kelurahan Pasarbatang Kabupaten Brebes.

2. Mewawancarai saudari Dinda selaku penari Sintren Dangdut mengenai ritual yang dilakukan sebelum pertunjukan Sintren dan bentuk gerak tari Sintren Dangdut Grup Putra Kelana di Keluraha Pasarbatang Kabupaten Brebes. 
3. Mewawancarai Ibu Musdah selaku pawang dalam pertunjukan Sintren Dangdut Putra Kelana, bertanya mengenai perlengkapan yang dibutuhkan dan langkah-langkah yang harus dilakukan sebelum dan sesudah pelaksanaan pertunjukan Sintren Dangdut. Selain itu bertanya mengenai upaya pelestarian seni tradisi Sintren Dangdut.

4. Mewawancarai Ibu Tarminah selaku salah satu sinden mengenai lagu-lagu yang dinyanyikan dalam pertunjukan Sintren Dangdut dan ritual yang dilakukan sebelum pelaksanaan Sintren Dangdut Grup Putra Kelana di Kelurahan Pasarbatang Kabupaten Brebes.

5. Mewawancarai Mba Firli selaku penyanyi dangdut dalam pertunjukan Sintren Dangdut grup Putra Kelana di Kelurahan Pasarbatang Kabupaten Brebes, bertanya mengenai lagu-lagu apa saja yang dinyanyikan dalam pertunjukan Sintren Dangdut.

6. Mewawancarai saudara Hendri selaku penari pendamping Sintren Dangdut mengenai tata rias dan busana bodhor serta ritual apa saja yang dilakukan sebelum dan sesudah pertunjukan Sintren Dangdut Grup Putra Kelana di Kelurahan Pasarbatang Kabupaten Brebes.

7. Mewawancarai Bapak Amad selaku salah satu pemusik mengenai alat musik yang di gunakan dalam pertunjukan Sintren Dangdut Grup Putra Kelana di Kelurahan Pasarbatang Kabupaten Brebes.

Peneliti melakukan penelitian dengan wawancara secermat mungkin selama proses latihan, persiapan pentas, dan pementasan kesenian Sintren 
Dangsut. Proses wawancara langsung digunakan alat bantu digital recorder, pulpen, buku tulis dan kamera foto untuk merekam hasil yang di wawancarai.

\subsubsection{Dokumentasi}

Husaini (2001: 73) mengatakan bahwa teknik pengumpulan data dengan dokumentasi ialah pengambilan data yang diperoleh melalui dokumen-dokumen. Sugiyono (2012: 329) dokumen merupakan catatan peristiwa yang sudah berlalu. Dokumen bisa berbentuk tulisan, gambar, atau karya-karya monumental dari seseorang. Maryono (2011: 108) bentuk dokumen tertulis dan arsip merupakan data yang sering menempati posisi penting pada penelitian kualitatif. Arikunto (2010: 274) menambahkan bahwa metode dokumentasi yaitu mencari data mengenai hal-hal atau variabel yang berupa catatan, transkip, buku, surat kabar, majalah, prasasti, notulen rapat, lengger, agenda, dan sebagainya.

Husaini (2001: 73) data-data yang dikumpulkan dengan teknik dokumentasi cenderung merupakan data sekunder. Sedangkan data-data yang dikumpulkan dengan teknik observasi dan wawancara cenderung merupakan data primer atau data yang langsung didapat dari pihak pertama. Teknik dokumentasi digunakan untuk memperoleh data tentang bentuk pertunjukan kesenian Sintren Dangdut sebagai Upaya Pelestarian Seni Tradisi pada Grup Putra Kelana. Pengumpulan dokumentasi digunakan untuk menambah informasi dan pengetahuan yang telah diberikan oleh para informan. Teknik dokumentasi dapat menguatkan data-data yang diperoleh melalui observasi dan wawancara. Studi dokumentasi ini dilakukan untuk mendapatkan foto-foto yang berhubungan dengan kegiatan pentas, video tentang kesenian Sintren Dangdut, dokumen 
sepertipemberitaan dalam surat kabar yang memuat kesenian Sintren Dangdut dan penghargaan yang pernah diterima.

\subsection{Teknik Analisis Data}

Analisis data dalam penelitian kualitatif berlangsung secara interaktif dan hasil pembahasannya dutarakan melalui kata-kata yang menghasilkan data deskriptif. Sugiyono (2012: 335) mengatakan bahwa analisis data adalah proses mencari dan menyusun secara sistematis data yang diperoleh dari hasil wawancara, catatan lapangan, dan dokumentasi, dengan cara mengorganisasikan data ke dalam kategori, menjabarkan ked dalam unit-unit, melakukan sitesa, menyusun ke dalam pola, memilih mana yang penting dan yang akan dipelajari, dan membuat kesimpulan sehingga mudah difahami oleh diri sendiri maupun orang lain. Maryono (2011: 123) menambahkan bentuk analisis penelitian kualitatif bersifat induktif, artinya semua simpulan dibentuk dari semua informasi yang diperoleh dari lapangan.

Sugiyono (2012: 336) analisis data dalam penelitian kualitatif dilakukan sejak sebelum memasuki lapangan, selama dilapangan, dan setelah selesai dilapangan. Pada saat wawancara, peneliti sudah melakukan analisis terhadap jawaban dari koresponden. Bila jawaban yang di wawancarai kurang memuaskan, maka peneliti mewawancarainya lagi sampai mendapatkan jawaban yang dibutuhkan. Adapun analisa data dalam penelitian bentuk pertunjukan kesenian Sintren Dangdut sebagai upaya pelestarian seni tradisi di Kelurahan Pasarbatang Kabupaten Brebes, meliputi: 


\subsubsection{Reduksi Data}

Reduksi data dalam penelitian dilakukan terus menerus selama penelitian berlangsung. Mereduksi data berarti merangkum, memilih hal-hal pokok, memfokuskan pada hal-hal yang penting, dicari tema dan polanya dan membuang yang tidak perlu. Dengan demikian data yang telah direduksi akan memberikan gambaran yang lebih jelas, dan mempermudah peneliti untuk melakukan pengumpulan data selanjutnya, dan mencarinya bila diperlukan (Sugiyono 2012: $338)$.

Data yang direduksi meliputi data wawancara responden dan informan, data monografi Kelurahan Pasarbatang Kabupaten Brebes, data tentang artikelartikel terkait kesenian Sintren Dangdut, data jurnal tentang kesenian Sintren Dangdut, data dari buku yang terkait dengan kesenian Sintren Dangdut.

Data yang diambil dari lapangan seperti wawancara dengan pemain kesenian Sintren Dangdut dikumpulkan semua dan dipilih dengan teliti atas dasar tujuan penelitian ini. Peneliti merangkum data yang diambil dari lapangan seperti data wawancara, data monografi Kelurahan Pasarbatang Kabupaten Brebes, data tentang artikel-artikel terkait kesenian Sintren Dangdut, data jurnal dan buku yang terkait dengan kesenian Sintren Dangdut, data tentang bentuk pertunjukan kesenian Sintren Dangdut. Data tersebut yang dirangkum diteliti dan dirinci dalam laptop akan memberikan gambaran kesenian Sintren Dangdut lebih jelas dan 
mempermudah penelitian kesenian Sintren Dangdut dalam pengumpulan data selanjutnya.

\subsubsection{Penyajian Data}

Langkah selanjutnya setelah data direduksi kemudian mendisplay data. Penyajian data bisa dilakukan dalam bentuk uraian singkat, bagan, hubungan antar kategori, flowchart dan sejenisnya. Yang paling sering digunakan untuk menyajikan data dalam penelitian kualitatif adalah dengan teks yang bersifat naratif. Dengan mendisplaykan data, maka akan memudahkan untuk memahami apa yang terjadi, merencanakan kerja selanjutnya berdasarkan apa yang telah difahami tersebut (Sugiyono 2012: 341).

Data yang disajikan berupa uraian singkat, bagan serta teks. Data dari wawancara dengan responden dan informan, data monografi Kelurahan Pasarbatang Kabupaten Brebes, data jurnal, artikel serta buku tentang kesenian Sintren Dangdut dan data bentuk pertunjukan kesenian Sintren Dangdut. Data reduksi yang telah dipilih, diteliti dan dirangkum kemudian di uraikan dalam teks yang bersifat naratif, dibuat bagan seperti data monografi Kelurahan Pasarbatang Kabupaten Brebes, Penyajian data kesenian Sintren Dangdut akan lebih mudah memahami apa yang terjadi pada kesenian Sintren Dangdut. Penyajian data pada penelitian kesenian Sintren Dangdut juga memfokuskan hal-hal yang dianggap baru dan belum diteliti sebelumnya.

\subsubsection{Penarikan Kesimpulan}

Penarikan kesimpulan adalah proses panjang dimana sampai pada proses pengumpulan data terakhir. Kesimpulan dalam penelitian kualitatif yang 
diharapkan adalah merupakan temuan baru yang sebelumnya belum pernah ada. Temuan dapat berupa deskripsi atau gambaran suatu obyek yang sebelumnya masih remang-remang atau gelap sehingga setelah diteliti menjadi jelas, dapat berupa hubungan kausal atau interaktif, hipotesis, atau teori (Sugiyono 2012: $345)$.

Peneliti melakukan penarikan kesimpulan dan verifikasi bentuk pertunjukan kesenian Sintren Dangdut sebagai upaya pelestarian seni tradisi grup Putra Kelana setelah mereduksi data dan memfokuskan hal-hal yang terkait dalam penyajian data dengan seluruh data yang diperoleh disajikan secara teks yang bersifat naratif, kemudian peneliti menarik kesimpulan sesuai dengan landasan teori yang digunakan dengan kenyataan yang dilakukan di lapangan. Kesimpulan bentuk pertunjukan kesenian Sintren Dangdut sebagai upaya pelestarian seni tradisi yang ditemukan dalam penelitian bisa sesuai dengan teori yang digunakan dan bahwa data yang ditemukan di lapangan bisa berbeda dengan teori yang digunakan.

Data tentang wawancara dengan informan, data monografi Kelurahan Pasarbatang Kabupaten Brebes, data artikel terkait Sintren Dangdut, data jurnal dan buku tentang Sintren Dangdut, data bentuk pertunjukan kesenian Sintren Dangdut, dari data-data tersebut setelah direduksi dan mendapat penemuanpenemuan baru kemudian penyajian data yang berpola dengan pokok permasalahan yang ada di tarik kesimpulan dari data-data tersebut agar jelas. Kesimpulan dari data-data dilapangan dengan didukung bukti-bukti yang ada tentang kesenian Sintren Dangdut adalah sama dan benar adanya. 
Model interaktif dalam analisis data ditunjukan pada gambar berikut ini:

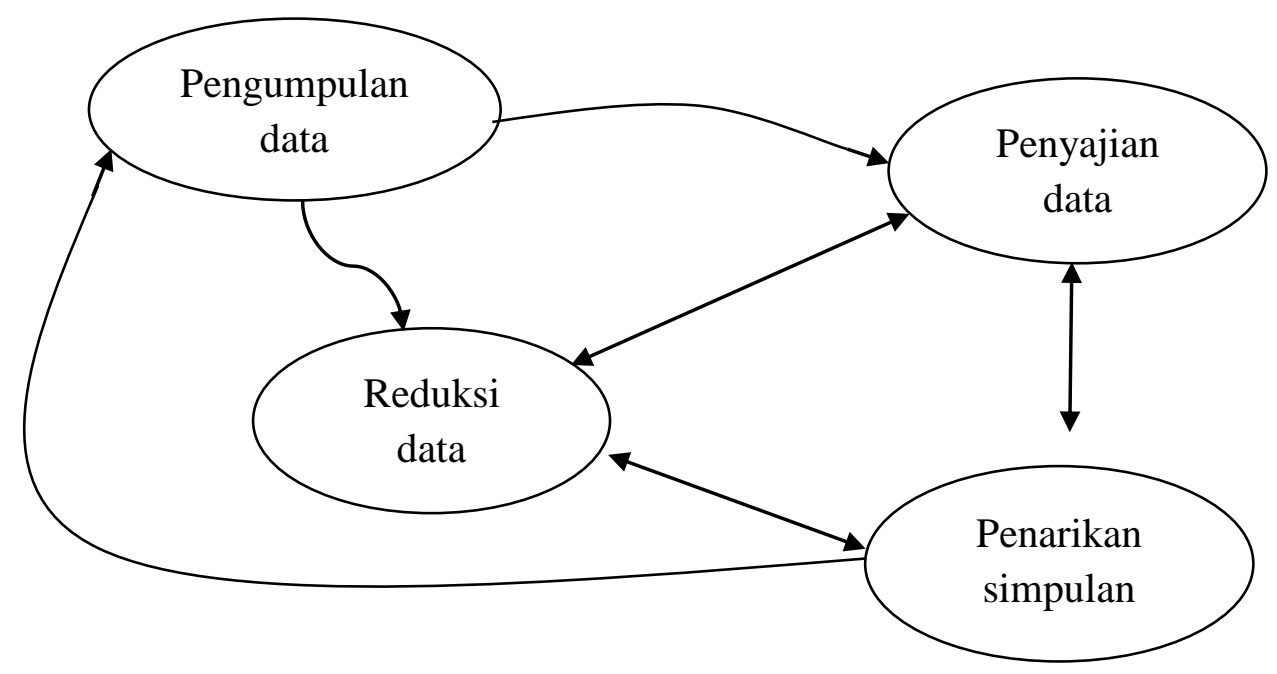

Bagan.3.1 Analisis Data

(model Miiles dan Huberman dalam Sugiyono 2012:338)

Keterangan bagan:

Pengumpulan data yang dilakukan adalah mencatat dengan rinci, kritis, dan lengkap kata-kata kunci yang ditemukan. Kemudian dikembangkan hasil pengumpulan data dari kata-kata kunci menjadi catatan lengkap.

Reduksi data, peneliti melakukan pengelompokan data menurut jenisnya secara terpisah berdasarkan kelompok informasinya dan merumuskan temuan jalinan dalam kelompok dengan rumusan singkat. Selain itu peneliti membandingkan data antar kelompok untuk menemukan kemungkinan adanya keragaman bentuk yang tekait.

Sajian data, disusun berdasarkan kelompok data yang sudah dirumuskan (reduksi data). Kemudian peneliti melakukan pengelompokan unit sajian berdasarkan kelompok rumusan masalah, yang dikembangkan berdasarkan 
temuan dari setiap kelompok data dan disajikan dalam bentuk narasi lengkap dan bukan sajian bahan mentah.

Penarikan simpulan/verifikasi, merupakan hasil pembahasan dari sajian data dan reduksi data untuk menyimpulkan makna tunggal yang menempatkan posisi setiap temuan berada pada satu kesatuan konteks (Maryono 2011: 129130).

\subsection{Teknik Pemeriksaan Keabsahan Data}

Triangulasi dalam pengujian kredibilitas ini diartikan sebagai pengecekan data dari berbagai sumber dengan berbagai cara, dan berbagai waktu. Dengan demikian terdapat triangulasi sumber, triangulasi teknik pengumpulan data, dan waktu (Sugiyono 2012: 372). Sedangkan Maryono (2011: 114) menambahkan triangulasi data merupakan teknik atau metode pengumpulan data yang sejenis dengan menggunakan beberapa sumber data yang berbeda. Bentuk triangulasi data dapat juga berdasarkan data yang sama atau satu jenis dengan memanfaatkan atau menggali informasinya dari satu jenis sumber data dari beberapa informan yang berbeda beda tingkatan atau posisinya.

\subsubsection{Triangulasi Sumber}

Triangulasi sumber untuk menguji kredibilitas data dilakukan dengan cara mengecek data yang telah diperoleh melalui beberapa sumber. Untuk menguji kredibilitas data tentang perilaku murid, maka pengumpulan dan pengujian data yang telah diperoleh dapat dilakukan ke guru, teman murid yang bersangkutan dan kedua orangtuanya. Data dari ketiga sumber tersebut, tidak bisa dirata-ratakan seperti dalam penelitian kuantitatif, dideskripsikan, dikategorisasikan, mana 
pandangan yang sama, yang berbeda, dan mana yang spesifik dari tiga sumber data tersebut. Data yang telah dianalisis oleh peneliti sehingga menghasilkan suatu kesimpulan selanjutnya dimintakan kesepakatan (member chcek) dengan tiga sumber data tersebut (Sugiyono 2012: 373).

Data tentang kesenian Sintren Dangdut diambil dari wawancara, dan wawancara itu dilakukan melalui beberapa sumber yang berbeda tingkatan posisi dalam grup kesenian Sintren Dangdut. Peneliti juga menguji pemahaman informan tentang kesenian Sintren Dangdut. Setelah dilakukan wawancara tentang kesenian Sintren Dangdut kemudian peneliti menguji pemahaman dan menarik kesimpulan tentang kesenian Sintren Dangdut. Pneliti juga menguji data dan mengecek pada beberapa artikel terkait kesenian Sintren Dangdut dan mengambil kesimpulan.

\subsubsection{Triangulasi Teknik}

Triangulasi teknik untuk menguji kredibilitas data dilakukan dengan cara mengecek data kepada sumber yang sama dengan teknik yang berbeda. Misalnya data diperoleh dari wawancara, lalu dicek dengan observasi dan dokumentasi. Bila dengan dua teknik pengujian kredibilitas data tersebut, menghasilkan data yang berbeda-beda, maka peneliti melakukan diskusi lebih lanjut kepada sumber data yang bersangkutan atau yang lain, untuk memastikan data mana yang dianggap benar. Atau mungkin semuanya benar, karena sudut pandangnya berbeda-beda (Sugiyono 2012: 373-374).

Data dari berbagai sumber wawancara diuji dengan cara teknik yang berbeda. Data hasil wawancara di cek melalui observasi dan dokumentasi dari 
kesenian Sintren Dangdut saat pementasaan maupun sehari-hari pada perkumpulan grup dirumah pimpinan grup kesenian Sintren Dangdut. Dari data wawancara dan observasi itu peneliti mendiskusikan dengan sumber data atau pimpinan grup kesenian Sintren Dangdut untuk memastikan data yang diperoleh adalah benar.

\subsubsection{Triangulasi Waktu}

Waktu juga sering mempengaruhi kredibilitas data. Data yang dikumpulkan dengan teknik wawancara di pagi hari pada saat narasumber masih segar, belum banyak masalah, akan memberikan data yang lebih valid sehingga lebih kredibel. Untuk itu dalam rangka pengujian kredibilitas data dapat dilakukan dengan cara melakukan pengecekan dengan wawancara, observasi atau teknik lain dalam waktu atau situasi yang berbeda. Bila hasil uji menghasilkan data yang berbeda, maka dilakukan secara berulang-ulang sehingga sampai ditemukan kepastian datanya.

Data yang dikumpulkan dengan cara wawancara dilakukan berulang kali, atau dengan waktu yang berbeda. Data pada pagi hari di cek kembali dengan data yang diambil pada siang atau malam hari. Pengecekan data tentang kesenian Sintren Dangdut dilakukan dengan satu, dua atau lebih narasumber yang berbeda tingkatan posisi pada grup kesenian Sintren Dangdut. Data wawancara juga diperkuat dengan data hasil observasi pada pagi hari, siang hari, dan malam hari. Pengecekan dilakukan terus menerus sampai ditemukan kepastian data tentang kesenian Sintren Dangdut. 


\section{BAB 4}

\section{HASIL PENELITIAN DAN PEMBAHASAN}

\subsection{Gambaran Umum Kelurahan Pasarbatang Kabupaten Brebes}

Kelurahan Pasarbatang merupakan salah satu kelurahan dari 23 kelurahan yang ada di Kecamatan Brebes Kabupaten Brebes Jawa Tengah yang terletak di bagian utara dari Provinsi Jawa Tengah. Batas wilayah Kelurahan Pasarbatang sebelah Utara Desa Sigambir, sebelah Selatan Kelurahan Brebes, sebelah Barat Desa Pesantunan, sebelah Timur Kelurahan Limbangan Kulon. Kelurahan Pasarbatang termasuk klasifikasi kelurahan dalam perkotaan. Kelurahan Pasarbatang hanya berjarak $3 \mathrm{~km}$ dari Ibukota kecamatan, jarak dari Ibukota Kabupaten 2 km, jarak dari Ibukota Propinsi 186 km, jarak Ibukota Negara 285 $\mathrm{km}$.

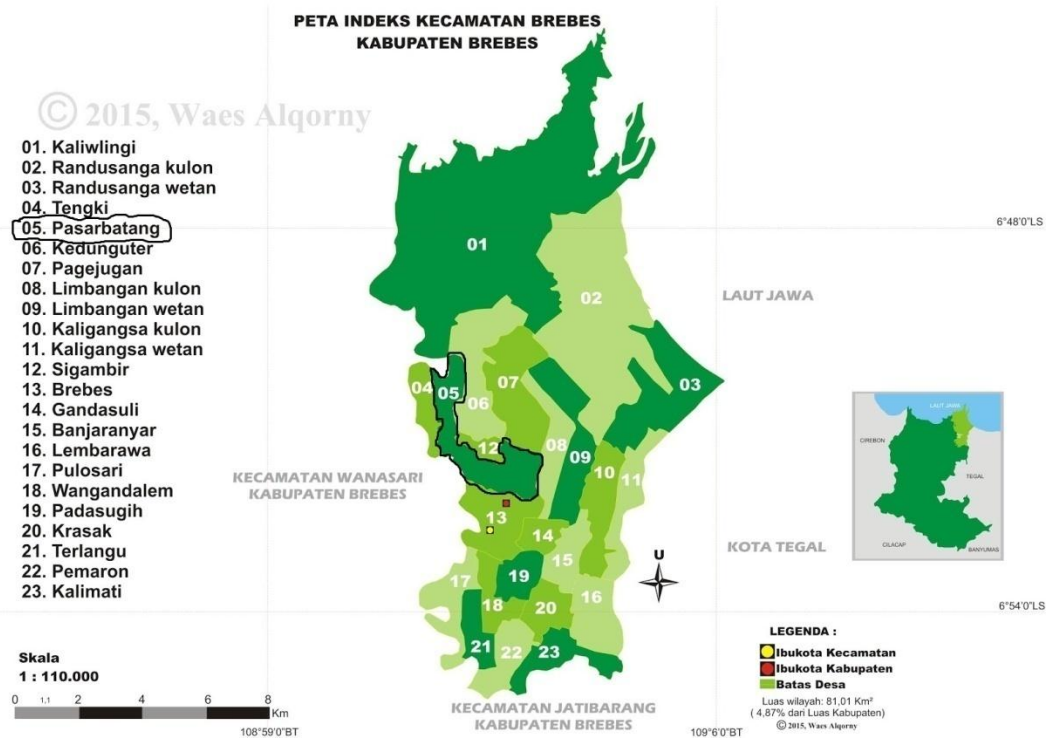

Gambar. 4.1

Peta Indeks Kecamatan Brebes 
Luas kelurahan Pasarbatang adalah 518 Ha, untuk luas lahan bukan sawah 220,27 Ha yang terbagi dari bangunan/pekarangan seluas 184,38 Ha, luas lahan sawah 297,67 Ha terbagi menjadi irigasi/pengairan teknis 225,62 Ha, irigasi/pengairan setengah teknis $63 \mathrm{Ha}$, irigasi/pengairan sederhana $7 \mathrm{Ha}$, dan tadah hujan 2 Ha. Banyaknya dusun/dukuh di Kelurahan Pasarbatang ada 1 dan mempunyai jumlah RW 14, jumlah RT 68. Kesenian Sintren Dangdut termasuk kesenian yang lahir dan berkembang di daerah kelurahan Pasarbatang (Monografi Kelurahan Pasarbatang 2015).

Keadaan jalan di Kelurahan Pasabatang yang sudah beraspal 339 km, dan jalan makadam (diperkeras dengan kerikil/batu) 27 km. Kelurahan Pasarbatang memiliki Sarana dan Prasarana Perekonomian seperti koperasi simpan pinjam 3 buah, bank umum non BPR 1 buah. Dalam industri tempat hiburan rekreasi, Kelurahan Pasarbatang mempunyai 1 tempat hiburan/rekreasi.

\subsubsection{Penduduk}

Jumlah penduduk di Kelurahan Pasarbatang adalah 18.552 jiwa, terdiri dari laki-laki 9.344 jiwa dan perempuan 9.208 jiwa (Monografi Kelurahan Pasarbatang bulan April 2015).

Tabel 3.1

Jumlah Penduduk Menurut Kelompok Umur

\begin{tabular}{|c|c|c|c|c|}
\hline No & Kelompok Umur & Laki-laki & Perempuan & Laki-laki+Perempuan \\
\hline 1 & $0-4$ & 727 & 860 & 1587 \\
\hline 2 & $5-9$ & 843 & 831 & 1674 \\
\hline 3 & $10-14$ & 867 & 843 & 1710 \\
\hline
\end{tabular}




\begin{tabular}{|c|c|c|c|c|}
\hline 4 & $15-19$ & 784 & 806 & 1590 \\
\hline 5 & $20-24$ & 981 & 817 & 1798 \\
\hline 6 & $25-29$ & 884 & 813 & 1697 \\
\hline 7 & $30-34$ & 893 & 893 & 1838 \\
\hline 8 & $35-39$ & 975 & 363 & 1531 \\
\hline 9 & $40-44$ & 793 & 738 & 795 \\
\hline 10 & $45-49$ & 329 & 829 & 625 \\
\hline 11 & $50-54$ & 475 & 320 & 938 \\
\hline 12 & $55-59$ & 367 & 258 & 325 \\
\hline 13 & $60-64$ & 289 & 149 & 18552 \\
\hline 14 & $65+$ & 137 & 188 & 9208 \\
\hline
\end{tabular}

Monografi Kelurahan Pasarbatang 15 April 2015

Berdasarkan tabel 3.1 diatas, jumlah penduduk menurut kelompok umur yang paling banyak pada genre laki-laki diantara umur 20-24 tahun yaitu 981, pada genre perempuan diantara umur 30-34 tahun yaitu 839. Sedangkan jumlah penduduk menurut kelompok umur pada laki-laki dan perempuan paling banyak pada umur 35-39 tahun yaitu 1838. Jumlah penduduk yang terkecil pada kelompok umur 65+ tahun yaitu di angka 325. Pada kelompok umur 35-39 tahun masih menyukai pertunjukan kesenian Sintren tetapi dengan ditambahnya musik dangdut ke dalam pertunjukan Sintren tersebut. Jumlah penduduk mempengaruhi berkembangnya kesenian Sintren Dangdut dalam Kelurahan Pasarbatang Kabupaten Brebes. Jika masyarakat sedikit yang berminat dengan pertunjukan 
kesenian Sintren Dangdut, kesenian itu akan cepat menurun perkembangannya. Tetapi jika masyarakat tertarik dengan pengembangan kesenian Sintren Dangdut, maka perkembangan kesenian itu akan pesat sampai keluar kota.

\subsubsection{Agama}

Masyarakat Kelurahan Pasarbatang mayoritas pemeluk agama Islam. Berdasarkan pengamatan sebagian besar masyarakat Kelurahan Pasarbatang merupakan santri, dilihat dari tempat ibadah yang mempunyai masjid 8 buah dan mushola 38 buah, kemudian Kelurahan Pasarbatang juga mempunyai 2 Pondok Pesantren yang mengajarkan banyak ilmu agama Islam dan untuk membina ketaatan terhadap Tuhan Yang Maha Esa.

Situasi agama yang masih mentradisi sampai sekarang masih hidup adalah tahlilan. Tahlilan dilakukan setelah ada orang meninggal penduduk kelurahan Pasarbatang lalu yasinan dan pengajian berdoa untuk orang yang sudah meninggal, tahlilan dilakukan tujuh hari berturut-turut. Acara tradisional yang masih dilakukan yang berlatar belakang agama Islam adalah Mauludan yang dilaksanakan pada bulan Maulud, guna memperingati hari kelahiran Nabi Muhammad SAW. Pada acara Mauludan biasanya panitia penyelenggara mendatangkan seorang Kyai (Da'i) terkenal untuk memberikan ceramah mengenai ajaran Islam. Kelurahan Pasarbatang juga mempunyai Kyai/Ustad dari penduduk Asli yang tinggal. Selain agama Islam, di Kelurahan Pasarbatang juga terdapat penduduk yang mempunyai agama berbeda seperti Kristen, Katolik, Hindu, dan Budha. Walaupun banyak perbedaan agama, tetapi kependudukan Kelurahan Pasarbatang saling menghormati satu sama lain. 
Tabel 3.2

Jumlah Penduduk Menurut Agama

\begin{tabular}{|c|c|c|}
\hline No & Pemeluk Agama & Jumlah \\
\hline 1 & Islam & 18.438 \\
\hline 2 & Kristen & 41 \\
\hline 3 & Katolik & 33 \\
\hline 4 & Hindu & 15 \\
\hline 5 & Budha & 25 \\
\hline 6 & Konghuchu & - \\
\hline
\end{tabular}

Monografi Kelurahan Pasarbatang 15 April 2015

Berdasarkan jumlah pemeluk agama yang ada di Kelurahan Pasarbatang, penduduk yang beragama Islam lebih banyak dan dari pemeluk agama Islam tersebut masyarakatnya masih mendukung adanya kesenian tradisional Sintren Dangdut. Biasanya kesenian tradisional Sintren Dangdut tampil pada malam hari sekitar jam 8 malam sampai jam 11 malam sehingga tidak mengganggu waktu sholat maupun suara adzan. Masyarakat sekitar juga tidak mempermasalahkan sesajen yang diadakan pada kesenian tradisional Sintren Dangdut karena itu semata-mata hanya untuk melestarikan kesenian tradisional saja.

\subsubsection{Mata Pencaharian}

Kelurahan Pasarbatang merupakan daerah pertanian dan industri oleh karena itu warga masyarakatnya terdiri dari buruh tani dan buruh industri. Hasil pertanian yang menjadi andalan kelurahan Pasarbatang adalah bawang merah, sedangkan hasil industri yang menjadi andalan kelurahan Paarbatang adalah 
tempe dan tahu. Kondisi tersebut menggambarkan bahwa Kelurahan pasarbatang merupakan kelurahan agraris.

Tabel 3.3

Mata Pencaharian Penduduk Kelurahan Pasarbatang

\begin{tabular}{|c|c|c|}
\hline No & Jenis Pekerjaan & Jumlah \\
\hline 1 & Petani Tanaman Pangan & 1.501 \\
\hline 2 & Petani Ternak & 110 \\
\hline 3 & Petani Tambak / kolam & - \\
\hline 4 & Buruh Tani & 3.529 \\
\hline 5 & Nelayan & 113 \\
\hline 6 & Pengusaha & 97 \\
\hline 7 & Buruh Industri / pabrik & 2.249 \\
\hline 8 & Buruh bangunan & 887 \\
\hline 9 & Pedagang & 391 \\
\hline 10 & Pekerja angkutan & 330 \\
\hline 11 & Pegawai Negeri Sipil & 331 \\
\hline 12 & Tentara / Polisi & 15 \\
\hline 13 & Pensiunan / Purnawirawan & 41 \\
\hline 14 & Pekerja Jasa & 50 \\
\hline 15 & Pekerja Swasta ( non buruh ) & 275 \\
\hline
\end{tabular}

Monografi Kelurahan Pasarbatang 15 April 2015

Berdasarkan catatan yang diperoleh Kelurahan Pasarbatang pada tahun 2015 dapat dilihat pada tabel 3 bahwa penduduk yang bermata pencaharian sebagai buruh tani 3.529 orang dan yang bekerja sebagai buruh industri / pabrik 
2.249 orang, oleh karena itu penduduk yang mempunyai mata pencaharian buruh maupun pedagang memilik waktu yang lebih banyak untuk melakukan kegiatan berkesenian. Adanya kesenian tradisional Sintren Dangdut juga memberi nilai tambah jika dilihat dari materi terutama bagi semua yang terkait dalam pertunjukan tradisional Sintren Dangdut. Pelaku pada pertunjukan Sintren Dangdut banyak yang bekerja sebagai buruh tani dan penduduk sebagian besar bekerja sebagai buruh tani bisa mendapat penghasilan lebih dari pertunjukan Sintren Dangdut.

Kesenian Sintren Dangdut dipertunjukan pada saat acara bersih desa, syukuran, sedekah laut, dan hajatan-hajatan. Pemain yang terlibat pada pertunjukan kesenian Sintren Dangdut akan mendapatkan uang saku sebagai penghasilan tambahan. Selain itu para pemain ikut melestarikan salah satu kesenian tradisional yang ada di Kelurahan Pasarbatang Kabupaten Brebes. Pelestarian yang dilakukan merupakan nilai tambah tersendiri sebagai penduduk Kelurahan Pasarbatang dan merupakan jiwa yang sadar akan kebudayaan masyarakat setempat

\subsubsection{Pendidikan}

Pendidikan di Kelurahan Pasarbatang sekarang sudah banyak mengalami kemajuan, hal itu dipengaruhi oleh kemajuan teknologi pada saat ini. Salah satunya adalah banyaknya warnet (warung internet) yang ada di Kelurahan Pasarbatang dapat memberikan informasi yang tidak terbatas. Selain itu kemudahan mendapatkan informasi tidak terbatas juga bisa melalui telepon 
selular, karena di Kelurahan Pasarbatang juga mempunyai 3 buah Tower Pemancar Selular (BPS).

Pendidikan sekarang yang semakin maju telah menyadarkan pada pola pikir masyarakat bahwa betapa pentingnya arti pendidikan bagi anak-anak, dengan demikian masyarakat Kelurahan Pasarbatang tidak jauh berbeda dari masyarakat Kelurahan yang lebih maju. Apalagi Kelurahan Pasarbatang termasuk kedalam klasifikasi Kelurahan Perkotaan dan dekat dengan kantor Bupati maupun alun-alun Kabupaten / Ibukota Brebes. Tingkat pendidikan di Kelurahan Pasarbatang relatif merata dari tingkat pendidikan dasar sampai perguruan tinggi baik negeri maupun swasta dan ada pula penduduk Kelurahan Pasarbatang yang mengeyam pendidikan sampai jenjang pasca sarjana.

Penduduk Kelurahan Pasarbatang pada umumnya sudah terbebas dari buta huruf, karena jarak Kelurahan Pasarbatang sudah dekat dengan Kabupaten Brebes dan ada fasilitas seperti Sekolah Dasar (SD/MI), Sekolah Menengah Pertama (SMP/MTs), Sekolah Menengah Atas (SMA/MA), dan Pendidikan Luar Sekolah seperti kejar paket A, B, dan C. Penduduk Kelurahan Pasarbatang juga rata-rata sudah bersekolah karena dilihat dari data tingkat pendidikan yang tidak/belum pernah sekolah tidak ada.

Tabel 3.4

Tingkat Pendidikan Kelurahan Pasarbatang

\begin{tabular}{|c|c|c|}
\hline No & Jenjang Pendidikan & Jumlah \\
\hline 1 & Tidak/belum pernah sekolah & - \\
\hline 2 & Tidak/belum tamat SD & 1663 \\
\hline
\end{tabular}




\begin{tabular}{|c|c|c|}
\hline 3 & Tamat SD/MI & 3421 \\
\hline 4 & Tamat SMP/MTs & 3363 \\
\hline 5 & Tamat SMA/MA & 3337 \\
\hline 6 & Tamat D-I/D-II & 81 \\
\hline 7 & Tamat D-III/Sarjana Muda & 133 \\
\hline 8 & Tamat S1/D-IV & 297 \\
\hline 9 & Tamat S2/S3 & 11 \\
\hline
\end{tabular}

Monografi Kelurahan Pasarbatang 15 April 2015

Jumlah tingkat pendidikan pada tebel 3.4 tercatat paling banyak tamatan SD yaitu dengan jumlah 3421 jiwa, kemudian urutan kedua adalah ditingkat tamatan SMP/MTs dan berikutnya tamatan SMA/MA. Pendidik yang tidak dapat melanjutkan ke jenjang pendidikan yang lebih tinggi banyak yang mengikuti kursus-kursus ketrampilan antara lain: komputer, menjahit, mengetik dan bordir. Memiliki modal ketrampilan tersebut banyak penduduk di Kelurahan Pasarbatang yang bekerja di industri, pedagang, dan pengusaha.

Jumlah tingkat pendidikan sangat berpengaruh pada kesenian Sintren Dangdut. Masyarakat yang berpendidikan tinggi akan mendukung dengan adanya acara pertunjukan kesenian Sintren Dangdut sebagai upaya pelestarian seni tradisi Sintren dalam Kelurahan Pasarbatang Kabupaten Brebes.

\subsubsection{Kemasyarakatan}

Sistem kemasyarakatan Kelurahan Pasarbatang sangat rukun. Sifat masyarakat saling bergotong royong jika mengadakan suatu acara syukuran, ataupun acara di berbagai masjid maupun mushola. Ada beberapa penduduk 
Kelurahan Pasarbatang yang menjadi TKI, jumlah laki-laki 3 dan perembuan 5, jadi jika ditotal jumlah penduduk TKI ada 8 jiwa. Walaupun banyak perbedaan agama, kepercayaan, beda pekerjaan tetapi di Kelurahan ini masih saling menghormati satu sama lainnya.

Saling membantu jika salah satu penduduk membutuhkan bantuan, dan persaingan perdagangan juga lancar. Kelurahan Pasarbatang pada masa sekarang ini sudah lebih maju dari yang dulu. Dilihat dari perdagangan yang sangat ramai di daerah Kelurahan Pasarbatang, warung internet (warnet) yang sudah menyebar. Adanya pondok pesantren di Kelurahan Pasarbatang juga menambah keramaian Kelurahan ini. Saat ini juga sudah banyak klinik pengobatan, rumah bersalin maupun praktek bidan yang ada di Kelurahan Pasarbatang, jadi penduduk tidak harus jauh-jauh kerumah sakit untuk ke periksa ke dokter maupun melahirkan karena sudah ada klinik di Kelurahan Pasarbatang. Berbagai apotik juga ada di Kelurahan Pasarbatang dan ada beberapa MCK/Jamban Umum di sekitar penduduk yang agak jauh dari pusat Kelurahan.

\subsection{Profil Grup Kesenian Sintren Dangdut "Putra Kelana"}

\subsubsection{Sejarah}

Grup kesenian Sintren Dangdut adalah bentuk grup kesenian tradisional yang yang dipimpin oleh Bapak Dalang Wertadiharjo. Grup kesenian tradisional ini sebagai wadah untuk melestarikan kesenian tradisional Sintren Dangdut. Sintren adalah kesenian tari tradisional masyarakat pesisir Jawa Tengah dan Jawa Barat antara lain Pekalongan, Pemalang, Brebes, Kuningan, Cirebon, dan 
Indramayu. Kesenian Sintren dikenal sebagai tarian dengan aroma mistis yang bersumber dari cerita cinta kasih Sulasih dengan Sulandono.

Bapak Dalang Wertadiharjo pimpinan grup Sintren Dangdut "Putra kelana", (wawancara 18 April 2016), mengatakan:

"Kesenian Sintren kue manjing Brebes sekitar tahun 1930-an. Urung akeh sing ngerti manjinge Sintren maring Brebes. Sintren kue kesenian sing Cirebon, dadi ngertine Bapak nelayan sing Cirebon nggawa kesenian kue maring Brebes soale Brebes karo Cirebon perek. Terus ning Brebes kesenian Sintren berkembang nganggo hiburan buruh tani, bisa di pentasna ning acara sedekah laut karo ning hajatan."

(Kesenian Sintren masuk Brebes sekitar tahun 1930-an. Belum banyak yang mengetahui masuknya Sintren ke Brebes. Sintren itu kesenian dari Cirebon, jadi ngerti Bapak nelayan dari Cirebon membawa kesenian itu ke Brebes karena Brebes dan Cirebon berdekatan. Kemudian di Brebes kesenian Sintren berkembang sebagai hiburan buruh tani, bisa di pentaskan di acara sedekah laut dan di hajatan.)

"Grup Sintren Putra Kelana kue turun-temurun sing mbahe aku nok. Dadi aku ya turunane Dalang mulane diarani Dalang. Aku mimpin Grup kie sekitar tahun 1981. Gemiyen Sintren urung ana dangdute, terus sekitar tahun 2009 di gabung karo musik dangdut. Soale wargane njaluk ana dangdute ben rame ora monoton Sintren tok."

(Grup Sintren Putra Kelana itu turun-temurun dari mbah aku. Jadi aku masih turunan Dalang kenapa dinamai Dalang. Aku memimpin Grup ini sekitar tahun 1981. Dahulu Sintren belum ada dangdutnya, kemudian sekitar tahun 2009 di gabung dengan musik dangdut. Karena warga meminta ada dangdut biar rame tidak monoton Sintren.)

Kesenian tradisional Sintren di Kabupaten Brebes berkembang sekitar tahun 1930-an. Belum banyak yang mengetahui dengan pasti masuknya Sintren di Kabupaten Brebes. Asal mula Sintren masuk ke Kabupaten Brebes dibawa oleh para nelayan dari Cirebon Jawa Barat, karena letak kabupaten Brebes berbatasan langsung dengan Cirebon Jawa Barat. Sintren berkembang didukung oleh warga buruh tani wilayah Kabupaten Brebes. Awal perkembangan Sintren sebagai sarana hiburan, Sintren juga digunakan sebagai mediasi pada saat sedekah laut, 
sekarang Sintren dipentaskan untuk memeriahkan hari-hari besar nasional, acara hajatan untuk menyambut tamu resmi.

Grup Sintren "Putra Kelana" di Kelurahan Pasarbatang Kabupaten Brebes berdiri sekitar tahun 1930-an dan pada tahun 1981 di pimpin oleh Bapak Dalang Wertadiharjo. Sebelum dipimpin oleh Bapak Dalang Wertadiharjo, grup kesenian Sintren ini di pimpin oleh Bapak Dalang Wasri yang diturunkan oleh Dalang Katon. Bapak Dalang Wertadiharjo juga masih ikut turunan Dalang Katon. Grup ini turun temurun dipimpin oleh turunan dari keluarga sedarah. Dahulu sebelum memasuki tahun 2009, grup kesenian ini masih menampilkan kesenian Sintren yang biasa tanpa diiringi atau diselingi musik dangdut. Musik dangdut dalam kesenian Sintren ini masuk sekitar tahun 2009-an, karena minat masyarakat yang menginginkan adanya musik dangdut, grup Putra Kelana ini mengkombinasikan kesenian Sintren dengan Dangdut, sehingga pada pertunjukan yang sekarang dinamakan kesenian Sintren Dangdut (wawancara Bapak Dalang 18 April 2016).

\subsubsection{Kegiatan}

Grup kesenian tradisional yang merupakan wadah pelestarian kebudayaan daerah memiliki banyak kegiatan. Bukan hanya sekedar kegiatan pementasan kesenian tradisional Sintren Dangdut, melainkan kegiatan-kegiatan pementasan kesenian daerah sekitarnya. Grup Putra Kelana ini juga mempunyai banyak kesenian tradisional yang menjadi wadah pelestarian.

Bapak Dalang Wertadiharjo pimpinan grup Sintren Dangdut "Putra kelana", (wawancara 18 April 2016), mengatakan:

"Grup kie ora mung Sintren Dangdut tok nok. Ning Grupe Bapak ana kesenian sing liyane misale jaipong dangdut, burok dangdut, kuda 
lumping terus orgen tunggal. Dadi selain kegiatan pentas Sintren Dangdut ya ana kegiatan kesenian sing liyane. Anggota neng grup kiye ya sedinadina kerja dagang karo buruh tani, soale angger pentas tok ora cukup kebutuhane. Tapi alhamdulillah pentase laris terus nok. Ari ana tawaran pentas biasane sewulan apa seminggu ngabari, saiki sing sering diminati keseniane Sintren Dangdut. Kesenian Sintren Dangdut wis pentas ning luar kota kaya ning tegal, pekalongan karo kota semarang ning polres." (arti bahasa Indonesia: Grup ini tidah hanya Sintren Dangdut saja. Pada Grup Bapak ada kesenian yang lainnya misal jaipong dangdut, burok dangdut, kuda lumping dan organ tunggal. Jadi selain kegiatan pentas Sintren Dangdut ada kegiatan kesenian yang lainnya. Anggota di Grup ini sehari-hari kerja dagang dan buruh tani, karena kalau pentas saja tidak cukup kebutuhannya. Tapi alhamdulillah pentas laris terus. Kalau ada tawaran pentas biasanya satu bulan apa satu minggu memberi kabar, sekarang yang sering diminati kesenian Sintren Dangdut. Kesenian Sintren Dangdut sudah pentas di luar kota seperti di tegal, pekalongan dan kota semarang di polres.)

Grup Putra Kelana ini juga menyediakan kesenian tradisional selain Sintren Dangdut yaitu jaipong dangdut, burok dangdut, kuda lumping serta organ tunggal. Jadi selain pertunjukan Sintren Dangdut, pada grup ini memiliki kegiatan pertunjukan kesenian yang lainnya. Anggota Grup Putra Kelana ini bekerja sehari-hari untuk mencukupi kebutuhan hidup selain pada pertunjukan yaitu berdagang, ada yang bertani juga ada pula yang ikut grup kesenian yang lain.

Tawaran pertunjukan sebelumnya terlebih dahulu diadakan latihan sebelum pentas. Jadi biasanya jika ada tanggapan maka penanggap harus memberi kabar terlebih dahulu kepada pimpinan grup sehingga anggota grup dapat meluangkan waktu untuk pertunjukan tersebut. Untuk sekarang ini, kesenian yang sering diminati oleh masyarakat yaitu Sintren Dangdut. Grup kesenian Sintren Dangdut ini dipentaskan bukan hanya pada Kelurahan maupun Kabupaten Brebes, melainkan sudah keluar kota seperti di kota Tegal, Pekalongan serta kota Semarang. 
4.2.3 Struktur Organisasi

Anggota Grup Kesenian Sintren "PUTRA KELANA"

Kelurahan Pasarbatang Kabupaten Brebes

1. Pimpinan : Bapak. Dalang Wertadiharjo

2. Pelindung : Bapak. Sugiarto, Polres Brebes

3. Sintren : Mala

4. Pawang : Ibu Musdah

5. Bodhor : Ipung

6. Sinden : Ibu Tarminah

7. Penyanyi Dangdut : Firli

8. Pemusik :
a. Melodi : Amad
b. Suling : Rahman
c. Kecrek : Ambari
d. Tutukan : Duha
e. Blampak : Rawad
f. Gong : Dalang

(wawancara Bapak Dalang 18 April 2016)

\subsection{Cerita Sintren}

Sintren mulai dikenal di pesisir kota Cirebon pada tahun 1930-an. Kehidupan rakyat pesisiran selalu memiliki tradisi yang kuat dan mengakar. Pada hakikatnya tradisi tersebut bermula dari keyakinan rakyat setempat terhadap nilainilai luhur nenek moyang, atau bahkan bisa jadi bermula dari kebiasaan atau 
permainan rakyat biasa yang kemudian menjadi tradisi yang luhur. Salah satu tradisi lama rakyat pesisiran pantai utara Jawa Barat tepatnya di Cirebon adalah Sintren. Asal mula lahirnya sintren berawal dari kebiasaan kaum ibu-ibu dan putri-putrinya membuat permainan sembari menunggu suami atau ayah mereka pulang dari mencari ikan di laut, kemudian permainan itu berubah menjadi permainan sakral menunggu para nelayan pulang. Kemudian pada perkembangannya sintren dimainkan oleh para nelayan sebagai pekerjaan sampingan (wawancara Bapak Dalang 20 April 2016)

Sintren dilatar belakangi kisah percintaan Ki Bahurekso dengan Dewi Rantamsari yang tidak direstui oleh ayah Ki Bahurekso, Sultan Agung Raja Mataram. Ayah Ki Bahurekso tidak setuju karena Dewi Rantamsari adalah seorang gadis desa biasa. Untuk memisahkan cinta keduanya, Sultan Agung memerintahkan Ki Bahurekso menyerang Belanda di Batavia. Bahurekso melaksanakan titah Raja berangkat ke Batavia dengan menggunakan perahu. Saat berpisah dengan Rantamsari itulah, Bahurekso memberikan sapu tangan sebagai tanda cinta. Tidak lama kemudian terdengar kabar bahwa Ki Bahurekso gugur dalam medan peperangan, sehingga Dewi Rantamsari begitu sedih mendengar orang yang dicintai dan dikasihi sudah meninggal. Terdorong rasa cintanya yang begitu besar dan tulus, maka Rantamsari berusaha melacak jejak gugurnya Bahurekso. Melalui perjalanan sepanjang wilayah pantai utara Rantamsari menyamar menjadi seorang penari sintren dengan nama Dewi Sulasih. Melalui bantuan sapu tangan pemberian Ki Bahurekso akhirnya Dewi Rantamsari dapat bertemu Ki Bahurekso yang sebenarnya masih hidup. Karena kegagalan Ki 
Bahurekso menyerang Batavia dan pasukannya banyak yang gugur, maka Ki Bahurekso tidak berani ke Mataram (wawancara Bapak Dalang 20 April 2016).

Keberadaan Sintren dan asal usulnya memang secara nyata tidak dapat dibuktikan, karena berupa kisah atau cerita saja. Namun masyarakat Kelurahan Pasarbatang masih percaya cerita atau kisah itu sehingga kesenian Sintren masih berkembang sampai sekarang. Perkembangan kesenian tradisional Sintren masih sering dipentaskan tetapi kebanyakan pertunjukan kesenian Sintren hanya hiburan semata karena dari minat masyarakat menginginkan adanya hiburan kesenian dangdut juga agar pertunjukan Sintren tidak monoton dan tidak begitu-begitu saja. Jadi, pada grup Putra Kelana memodifikasian kesenian Sintren dengan dangdut sehingga menjadi kesenian Sintren Dangdut. Dan dalam pelaksanaan pertunjukannya kesenian Sintren bercampur dengan dangdut, pada saat Sintren didalam kurungan maupun diluar kurungan saat selingan memainkan musik dangdut (wawancara Bapak Dalang 20 April 2016).

\subsection{Bentuk Pertunjukan Kesenian Sintren Dangdut pada Grup Putra Kelana di Kelurahan Pasarbatang Kabupaten Brebes}

Berdasarkan konsep pada landasan teoretis, peneliti mengacu pada dua konsep Soedarsono dengan Kusmayati yang membagi seni pertunjukan menjadi beberapa aspek. Aspek-aspek tersebut antara lain lakon, gerak, pelaku, iringan, rias, busana, tata pentas, properti, penonton, dan urutan pertunjukan.

\subsubsection{Lakon}

Lakon pada pertunjukan Sintren Dangdut yaitu pelaku Sintren itu sendiri. Lakon Sintren berperan sebagai pelaku utama dalam pertunjukan Sintren Dangdut, syaratnya sama dengan Sintren yang lainnya yaitu seorang gadis yang 
masih suci (perawan), belum akil baliq, belum menikah atau bersuami yang telah dirasuki roh bidadari maupun roh dewi-dewi (makhluk gaib), berusia 12-15 tahun. Roh dewi yang memasuki penari Sintren sekitar ada 3 dewi yaitu Dewi Lanjar, Dewi Rantamsari, dan Dewi Sri (wawancara Bapak Dalang, 15 April 2016).

\subsubsection{Gerak}

Gerakan tari yang dilakukan oleh Sintren Dangdut bukan atas kemauannya sendiri, melainkan karena adanya roh bidadari (makhluk ghaib) yang memasuki tubuhnya. Gerak yang ditarikan oleh penari Sintren Dangdut pada saat pertunjukan kesenian Sintren Dangdut antara lain sembahan duduk, sembahan berdiri, gerak kaki berjingkat-jingkat, pinggul bergoyang, tangan ukel seblak sampur, kepala melenggok-lenggok. Tidak ada pola gerakan yang digarap pada saat sebelum pertunjukan Sintren Dangdut dimulai. Jadi gerakan yang dilakukan hanya diulang-ulang (monoton) tidak ada patokan yang membatasi dalam bergerak. Lincah tidaknya gerakan yang ditarikan oleh penari Sintren Dangdut tergantung dari roh yang merasukinya. Setelah dianggap cukup dinikmati oleh penonton, Sintren Dangdut yang masih dalam keadaan intrance (kesurupan) dimasukkan lagi dalam kurungan sebagai tanda pergantian tembang atau nyanyian (wawancara Ibu Musdah, 16 April 2016).

\subsubsection{Pelaku}

Semua jenis seni pertunjukan memerlukan penyaji sebagai pemain atau pelaku kesenian artinya seorang yang terlibat langsung atau tidak langsung dalam menyajikan kesenian. Kesenian Sintren Dangdut melibatkan pelaku laki-laki dan perempuan, selain pemeran utama yaitu pelaku Sintren, pemain kesenian Sintren 
Dangdut tidak terpaku pada usia. Para pelaku pada pertunjukan Sintren Dangdut terdiri dari:

1) Pemeran Sintren

Pemeran Sintren berperan sebagai pelaku utama dalam pertunjukan Sintren Dangdut, syaratnya sama dengan Sintren yang lainnya yaitu seorang gadis yang masih suci (perawan), belum akil baliq, belum menikah atau bersuami yang telah dirasuki roh bidadari maupun roh dewi-dewi (makhluk gaib), berusia 12-15 tahun. Roh dewi yang memasuki penari Sintren sekitar ada 3 dewi yaitu Dewi Lanjar, Dewi Rantamsari, dan Dewi Sri. Mala pemain Sintren Dangdut, (wawancara 10 April 2016), mengatakan:

"ora ana syarat maning kecuali durung nikah. Tapi biasane sing dadi Sintren kue wis ana keturunan. Gemiyen mamake aku dadi Sintren, terus bar kue dilanjut aku. Pas ning kurungan ora ngrasakna apaapa. Aku wis ora sadar, nari ben ora sadar mba. Makane aku pengin weruh video narine aku sing dadi Sintren. Jare wong tua ari dadi Sintren ayu terus mengko akeh sing seneng, aku ya melu bae nerusna keturunan ben ora punah. Sedina-dina aku sekolah, ari ana pentas kan bengi biasane jam 8 nganti jam 11."

(tidak ada syarat lagi kecuali belum menikah. Tetapi biasanya yang menjadi Sintren sudah ada keturunannya. Dahulu ibu aku jadi Sintren, kemudian setelah itu dilanjut aku. Waktu di kurungan tidak merasakan apa-apa. Aku sudah tidak sadar, nari juga sudah tidak sadar mba. Makannya aku ingin lihat video narinya aku yang menjadi Sintren. Kata orang tua kalau jadi Sintren cantik terus nanti banyak yang suka, aku ya ikut saja meneruskan keturunan biar tidak punah. Sehari-hari aku sekolah, kalau ada pentas malam biasanya jam 8 sampai jam 11.)

2) Pawang

Pawang merupakan orang yang bertugas memanggil roh bidadari atau dan dewi-dewi (makhluk gaib) dan menyadarkan Sintren setelah pertunjukan selesai. Pawang juga menyiapkan peralatan dari Sintren seperti baju ganti 
Sintren saat di kurungan dan sajen untuk pertunjukan. Pawang Sintren bernama Ibu Musdah yang berusia 59 tahun dan Ibu Tisnah berusia 39 tahun.

Ibu Musdah sebagai pawang Sintren, (wawancara 18 April 2016), mengatakan:

"Sing dadi pawang kue biasane ya turun temurun nok. Aku kie ana turunane sing neng keluarga. Dadi pawang biasane puasa ndisit sadina sadurunge pentas ben pas pentas acarane lancar. Sedurunge pentas kue aku karo lisna biasane nyiapna sajen nyiapna kebutuhane Sintren kaya klambi nganggo ganti Sintren ning kurungan." (yang jadi pawang biasanya turun temurun. Aku ini ada keturunannya dari keluarga. Jadi pawang biasanya puasa dahulu sehari sebelum pentas agar sewaktu pentas acaranya lancar. Sebelum pentas aku sama lisna biasanya menyiapkan sajen menyiapkan kebutuhannya Sintren seperti baju untuk ganti Sintren saat di kurungan.)

3) Bodhor

Bodhor merupakan penari laki-laki yang nantinya dipasangkan dengan penari Sintren. Bodhor diibaratkan dalam cerita yaitu Ki Bahurekso, yang hidup bersama dengan Dewi Rantamsari. Bodhor selalu mendampingi Sintren dalam setiap adegan pertunjukan. Bodhor bernama Ipung yang berusia 12-15 tahun. Ipung sebagai penari bodhor, (wawancara 10 April 2016), mengatakan:

"Aku wis suwe melu Grup Sintren Putra Kelana sekitar 5 wulan. Persiapan sadurunge pertunjukan laka ya, ora dikongkon puasa. Jare wong tua apa kepercayaan ning kene kue ari dadi penari bodhor mengko gedene akeh sing naksir, aku si percaya ora percaya. Tapi keluarga aku ora ngelarang aku dadi penari bodhor."

(aku sudah lama ikut Grup Sintren Putra Kelana sekitar 5 bulan. Persiapan sebelum pertunjukan tidak ada, tidak disuruh puasa. Kata orang tua kepercayaan disini jika menjadi penari Bodhor nanti dewasa banyak yang suka, aku percaya tidak percaya. Tetapi keluarga aku tidak melarang aku jadi penari bodhor.) 
4) Sinden

Sinden merupakan penyanyi yang bertugas menyajikan lagu-lagu Sintren dalam pertunjukan Sintren Dangdut. Sinden dalam pertunjukan Sintren Dangdut hanya satu orang saja. Sinden bernama Ibu Tarminah yang berusia 50 tahun. Ibu Tarminah sebagai sinden, (wawancara 18 April 2016), mengatakan:

"Aku melu Grup Putra Kelana kie wis puluhan tahun. Selain ning grup kesenian Sintren Putra Kelana aku biasane pentas karo Grup liyane sing esih daerah Brebes. Sadurunge pentas Sintren Dangdut laka ritual khusus. Aku biasane dikongkon nyanyi lagu-lagune Sintren tok. Ari lagu-lagu dangdut biasane uwis ana biduane dewek."

(aku mengikuti Grup Putra Kelana sudah puluhan tahun. Selain di grup kesenian Sintren Putra Kelana aku biasanya pentas dengan grup lainnya yang masih daerah Brebes. Sebelum pentas Sintren Dangdut tidak ada ritual khusus. Aku biasanya disuruh nyanyi lagu-lagu Sintren saja. Kalau lagu-lagu dangdut biasanya sudah ada biduannya sendiri.)

5) Penyanyi Dangdut

Penyanyi dangdut dalam pertunjukan kesenian Sintren Dangdut bertugas menyajikan lagu-lagu dangdut pantura. Penyanyi dangdut biasanya terdiri dari 310 orang, semuanya terdiri dari wanita. Usia penyanyi dangdut yaitu antara 2537 tahun. Firli sebagai biduan, (wawancara 11 April 2016), mengatakan:

"Aku melu Grup Sintren Putra Kelana ya wis suwe, kadang dinggo kadang ya ora tergantung panggilan pimpinane. Biasane biduan ning pentas Sintren sekitar 3-10 uwong. Persiapane ari pan pentas ya biasa ora reka-reka wong aku nyanyi dangdut tok kanggo selingan Sintren. Biasane aku nganggo klambi ya biasa sing terbuka kaya biduan-biduan sing liyane."

(aku mengikuti Grup Sintren Putra Kelana sudah lama, kadang dipakai kadang juga tidak tergantung panggilan pimpinan grup. Biasanya biduan yang dipentaskan di Sintren sekitar 3-10 orang. Persiapan jika mau pentas tidak macam-macam soalnya aku nyanyi dangdut saja dipakai untuk selingan Sintren. Biasanya aku memakai baju ya biasa yang terbuka seperti biduan-biduan yang lainnya.) 
6) Kemladang

Kemladang yaitu orang yang bertugas membantu pawang dalam memenuhi kebutuhan Sintren, seperti membuka dan menutup kurungan, mengasapi Sintren dengan asap pembakaran kemenyan, mengantar penari bodhor pada saat temoan dan balangan. Kemladang juga yang mengawasi penari bodhor saat mendampingi Sintren dalam pertunjukan. Kemladang bernama Bapak Wasrih yang berusia 45 tahun (wawancara Bapak Dalang 20 April 2016).

7) Pemusik

Pemusik merupakan penabuh alat musik pada saat pertunjukan Sintren Dangdut. Pemusik terdiri dari pria dengan jumlah 6 orang, yaitu Bapak Amad penabuh melodi, Bapak Rahman penabuh suling, Bapak Ambari penabuh kecrek, Bapak Duha penabuh tutukan, Bapak Rawad penabuh blampak/kendang, dan Bapak Dalang penabuh gong. Usia pemusik yaitu antara 45-60 tahun.

Amad sebagai pemegang melodi, (wawancara 15 April 2016), mengatakan:

"Aku biasa main melodi nok. Alat musik sing digunakaken Grup Putra Kelana wis modern, ora nganggo gamelan lengkap tapi wis ngganggo melodi gitar, orgen, suling, tetep ana kendhang, kecrek, tutukan karo gong. Aku wis suwe melu grup Putra Kelana."

(aku biasa memainkan melodi. Alat musik yang digunakan Grup Putra Kelana sudah modern, tidak memakai gamelan lengkap tetapi sudah memakai melodi gitar, orgen, suling, tetap ada kendhang, kecrek, tutukan sama gong. Aku sudah lama ikut Grup Putra Kelana).

8) Pembawa Acara

Pembawa acara dalam pertunjukan Sintren Dangdut sangat dibutuhkan.

MC merupakan pembawa acara, mc lah yang membuka dan menutup pertunjukan 
kesenian Sintren berlangsung. MC menyampaikan susunan acara, menyampaikan urutan pertunjukan, mc kadang juga mengucapkan selamat datang serta salam kepada pengunjung (wawancara Bapak Dalang 20 April 2016).

4.4.4 Iringan

Bapak Dalang pimpinan grup Putra Kelana, (wawancara 15 April 2016), mengatakan:

"Alat musik ning kesenian Sintren Dangdut kue wis ora nganggo gamelan lengkap. Dadi alat musike nganggo alat musik sing Jawa Barat gabungan karo alat musik modern. Alat musik sing nggo patokan kue ya melodi dudu kendhang, melodi manjing terus tembe kendhang ngikuti. Ning kene sing maksude melodi kue kaya gitar elektrik nok, ana maning suling ya bisa. Tapi sing wajib ana ya gitar elektrik kue. Kendhang mung nggo penentu tempo."

(Alat musik di kesenian Sintren Dangdut itu sudah tidak pakai gamelan lengkap. Jadi alat musiknya pakai alat musik dari Jawa Barat gabungan dengan alat musik modern. Alat musik itu patokannya ya melodi bukan kendhang, melodi masuk terus baru kendhang mengikuti. Di sini yang dimaksud melodi itu seperti gitar elektrik, ada lagi suling ya bisa. Tetapi yang wajib ya gitar elektrik itu. Kendhang hanya menjadi penentu tempo.)

Alat musik pada kesenian Sintren Dangdut merupakan alat musik dari Jawa Barat dan gabungan dengan alat musik modern. Gitar elektrik sangat berperan sekali (wajib) ada dalam kesenian Sintren Dangdut sebagai pembawa melodi, ada juga alat musik lain sebagai pembawa melodi yaitu suling. Gitar elektrik dalam kesenian Sintren Dangdut tidak berfungsi sebagai pengiring (tidak memainkan akor/kunci), tetapi gitar elektrik berperan sebagai melodi. Sedangkan alat musik gendhang berperan sebagai penentu tempo pada musik pengiring tarian Sintren Dangdut. Adapun alat musik yang digunakan adalah gitar elektrik, suling, kecrek, tutukan, blampak/kendhang, keyboard dan gong (wawancara Bapak Amad 19 April 2016). 
Pada saat mengiringi pertunjukan kesenian Sintren Dangdut, pola iringan musik yang digunakan dalam memainkan lagu berpola sama, akan tetapi syairsyair lagu bermacam-macam yang disesuaikan dengann situasi dan kehendak penari Sintren Dangdut. Ketika membawakan tariannya pelaku utama Sintren Dangdut bergerak monoton yaitu gerakan sama namun diulang-ulang akan tetapi masih seirama dengan alunan musik modern. Perbedaan dari kesenian Sintren Dangdut Brebes dengan kesenian Sintren yang didaerah lain adalah pada alat musik pengiringnya yang sudah modern dan terdapat selingan dangdut yang dipadukan pada saat pertunjukan Sintren Dangdut (wawancara Bapak Amad 19 April 2016).

Pada pertunjukan kesenian Sintren Dangdut tidak lepas dari jenis-jenis tembang, karena tembang dalam kesenian Sintren Dangdut merupakan tembang iringan yang mempunyai daya tarik sebagai mantra. Pada setiap syair tembang Sintren Dangdut terdapat doa-doa atau mantra-mantra sehingga peran sinden sangat penting dalam sebuah pertunjukan kesenian Sintren Dangdut. Tembangtembang dalam pertunjukan kesenian Sintren Dangdut yang memiliki simbol yaitu: Tembang Turun Sintren sebagai simbol untuk mengundang penonton agar pertunjukan ramai disaksikan oleh para penonton. Tembang Simbar Melati menyimbolkan Sintren Dangdut memakai melati di dalam kurungan. Tembang Widadari menyimbolkan roh bidadari mendekati Sintren yang dipercaya sebagai Dewi Rantamsari agar membantu Sintren dalam berbusana dan berhias didalam kurungan serta merasuk kedalam tubuh penari Sintren agar terlihat cantik dan luwes dalam menari. Tembang Jamang Topi menyimbolkan Sintren sedang 
mencari bodhor atau pendamping, setelah bodhor datang ikut menari dengan Sintren. Tembang Kembang Mawar menyimbolkan keikhlasan, penari Sintren dan bodhor meminta temoan berharap agar sesama manusia harus saling tolongmenolong dan memberi dengan rasa ikhlasnya. Tembang Semang-semang menyimbolkan bahwa penari Sintren dan bodhor jual kembang dan kembang itu kembang pengasihan. Tembang Bapak Tani menyimbolkan suatu rumah tangga yang rukun. Tembang Umbul-Umbul menyimbolkan keahlian Sintren Dangdut (ciri khas Sintren Dangdut). Tembang Pitik Walik menyimbolkan keahlian Sintren Dangdut (ciri khas Sintren Dangdut naik kurungan). Tembang Tangis-Tangis Layung menyimbolkan roh dewi-dewi yang sudah jadi arwah agar tidak mengganggu manusia yang masih hidup di dunia (wawancara Ibu Tarminah 19 April 2016).

(1) Tembang Turun Sintren

Tembang turun sintren digunakan untuk memanggil atau mengumpulkan penonton. Pada saat tembang turun sintren dilantunkan penari Sintren Dangdut masih berada diluar kurungan, pawang menyiapkan perlengkapan yang digunakan dalam pertunjukan Sintren Dangdut. Adapun tembang turun sintren, wawancara dengan Bapak Amad dan Ibu Tarminah 10 April 2016 sebagi berikut: 

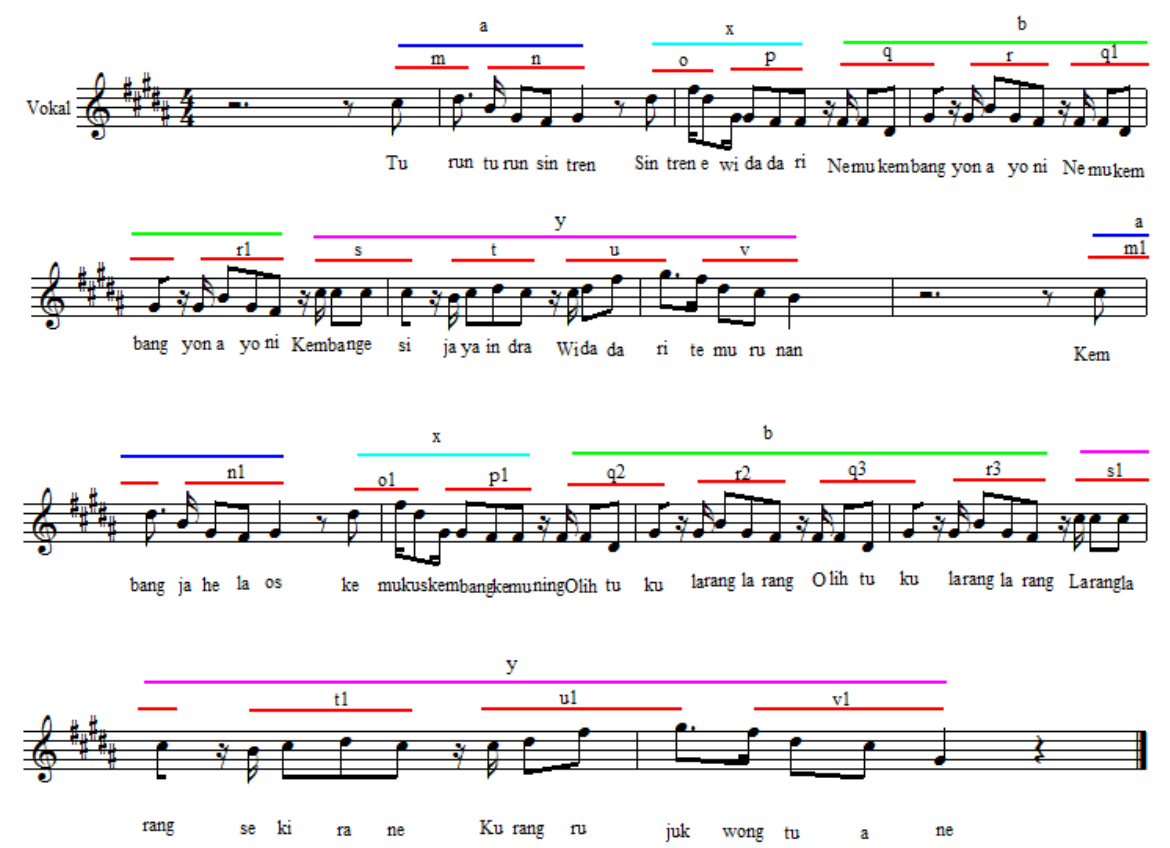

Keterangan:

- Garis berwarna biru tua (a) menunjukan kalimat antiseden (kalimat tanya).

- Garis berwarna biru muda (x) menunjukan kalimat konsekuen (kalimat jawab).

- Garis berwarna hijau muda (b) menunjukan kalimat antiseden (kalimat tanya) tapi berbeda pola.

- Garis berwarna ungu (y) menunjukan kalimat konsekuen (kalimat jawab) tetapi berbeda pola.

- Garis berwarna merah $(\mathrm{m}, \mathrm{n}, \mathrm{o}, \ldots)$ menunjukan motif.

Alat musik yang digunakan dalam pertunjukan Sintren Dangdut berbeda dengan pertunjukan Sintren yang lainnya. Pada grup Putra Kelana 
menggunakan alat musik modern jadi sudah tidak menggunakan gamelan. Pada alat musik gitar listrik berfungsi sebagai melodi utama dan dibahas pada upaya pelestarian seni tradisi Sintren Dangdut bagian pengembangan musik dan iringan.

(2) Tembang Bapak Tani

Tembang bapak tani dinyanyikan saat adegan suatu rumah tangga yang rukun. Sintren dan bodhor diibaratkan sebagai suami istri yang saling gotong royong saling membantu. Saat bodhor bekerja disawah, Sintren ikut membantu dan sewaktu mereka berdua istirahat dari persawahan mereka makan bersama dengan makanan masakan Sintren sendiri. Adapun vocal tembang tersebut, wawancara dengan Bapak Amad dan Ibu Tarminah 10 April 2016 adalah:

Tembang Bapak Tani

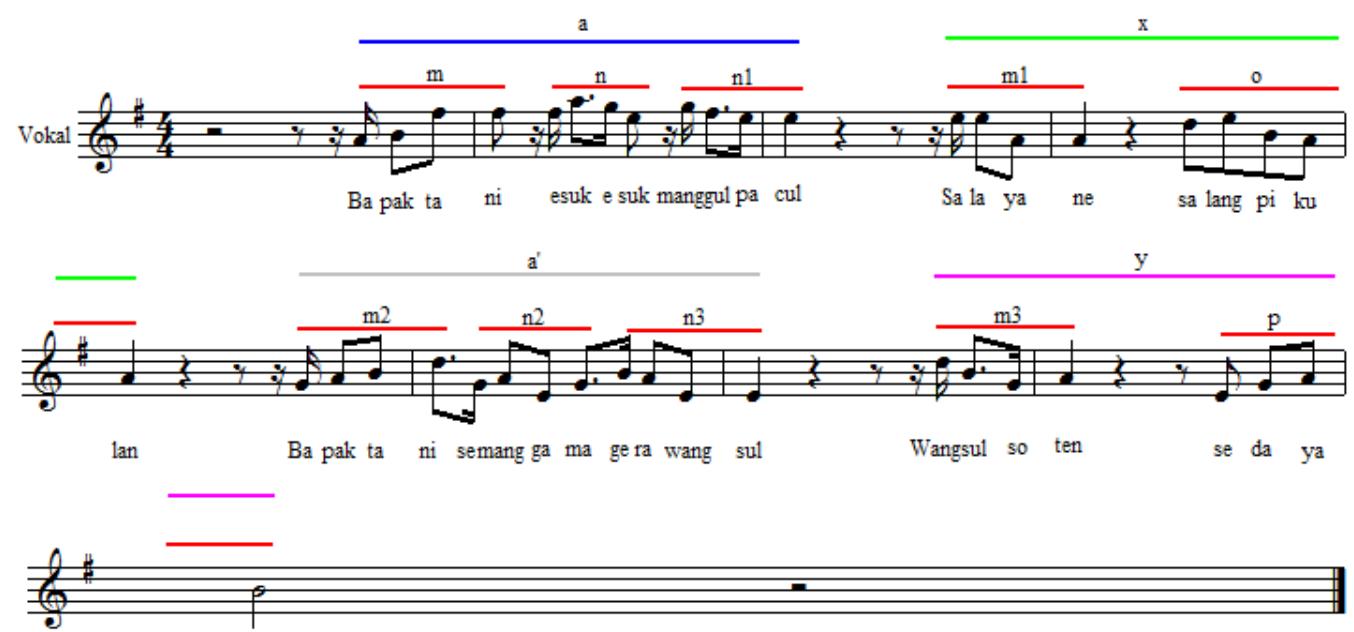

na 


\section{Keterangan:}

- Garis berwarna biru tua (a) menunjukan kalimat antiseden (kalimat tanya).

- Garis berwarna biru muda (x) menunjukan kalimat konsekuen (kalimat jawab).

- Garis berwarna hijau muda (b) menunjukan kalimat antiseden (kalimat tanya) tapi berbeda pola.

- Garis berwarna ungu (y) menunjukan kalimat konsekuen (kalimat jawab) tetapi berbeda pola.

Garis berwarna merah $(\mathrm{m}, \mathrm{n}, \mathrm{o}, \ldots$. . ) menunjukan motif.

\subsubsection{Rias}

Tata rias wajah pada kesenian Sintren Dangdut grup Putra Kelana menggunakan tata rias wajah cantik dan karakter. Tata rias wajah yang dipakai Sintren, menggunakan rias korektif make-up yaitu tata rias wajah cantik. Tata rias wajah penari Sintren menyimbolkan kesederhanaan tanpa mengurangi nilai keindahan dari penari Sintren tersebut.

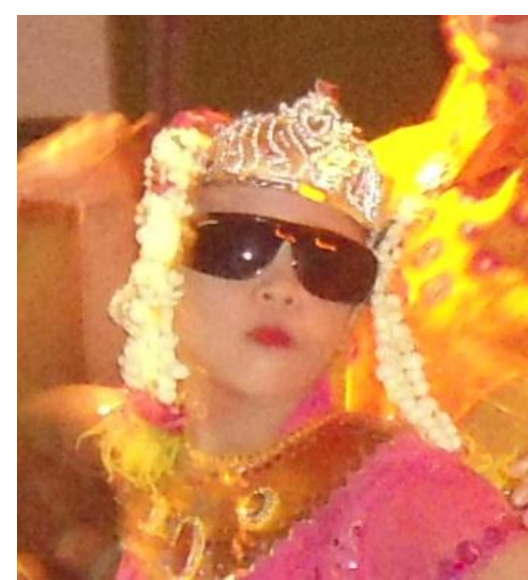

Foto 4.1 Tata Rias Sintren Dangdut (foto: Amalia Mega, Brebes april 2016) 
Ibu Musdah sebagai pawang Sintren, (wawancara 12 April 2016), mengatakan:

"Sing dadi Sintren kue biasane ana turunane, ari laka turunane
arwah dewi angel manjing maring sintrene. Kue rias sintren rias
biasa soale sing ngerias dewi-dewine. Terus sing nganggoni
klambi ya dewi-dewinw kue. Pas manjing kurungan sintren wis ora
sadar."
(yang jadi Sintren itu biasanya ada turunan, jika tidak turunan
arwah dewi susah masuk ke sintren. Itu rias sintren rias biasa
karena yang merias dewi-dewi. Kemudian yang memakaikan baju
ya dewi-dewi itu. Sewaktu masuk kurungan sintren sudah tidak
sadar.)

Bagian kepala rias Sintren Dangdut memakai mahkota, dan rangkaian bunga melati, mawar dan kenanga karena tanpa bunga kenanga Sintren Dangdut tidak bisa intrance (kesurupan). Tata rias rambut hanya menggunakan roncean bunga melati. Roncean bunga melati yang putih dan berbau harum menyimbolkan sebuah kesucian penari Sintren Dangdut.

Tata rias untuk bodhor menggunakan rias karakter laki-laki. Dan kepala bodhor dililikan kain berwarna sama dengan bajunya. Selain baju dan juga celana, bodhor menggunakan kain yang dililitkan di pinggul. Bodhor ini membuat pertunjukan semakin meriah karena keluwesan penari laki-laki ini (wawancara Ibu Musdah 20 April 2016).

\subsubsection{Busana}

Busana yang digunakan pada kesenian Sintren Dangdut dibuat sendiri dengan bahan yang relatif murah, mudah didapat tetapi dapat mendukung penampilan, karena busana kesenian Sintren Dangdut menggunakan busana yang dipakai sehari-hari. Busana yang digunakan antara lain: kain, kemben, kebaya, baju atasan, baju bawahan/rok, kaos atas, selendang, mahkota, dan bunga melati 
mawar kenanga serta beberapa aksesoris yang cocok seperti kalung, giwang, gelang, cincin, kaos kaki warna putih dan kacamata hitam (wawancara Ibu Musdah, 16 April 2016).

Warna busana yang digunakan penari Sintren Dangdut dan kesenian pesisir identik dengan warna busana yang menyolok. Penari Sintren Dangdut menggunakan busana dan selendang warna merah muda menyimbolkan keagungan. Jarik berwarna putih corak coklat menyimbolkan keagungan. Busana kebaya berwarna hijau dan selendang hijau menyimbolkan kedinamisan. Warna selendang kuning menyimbolkan keceriaan atau berkesan gembira. Warna hitam pada kacamata yang dipakai menyimbolkan kegelapan, kesedihan (wawancara Ibu Musdah, 16 April 2016).

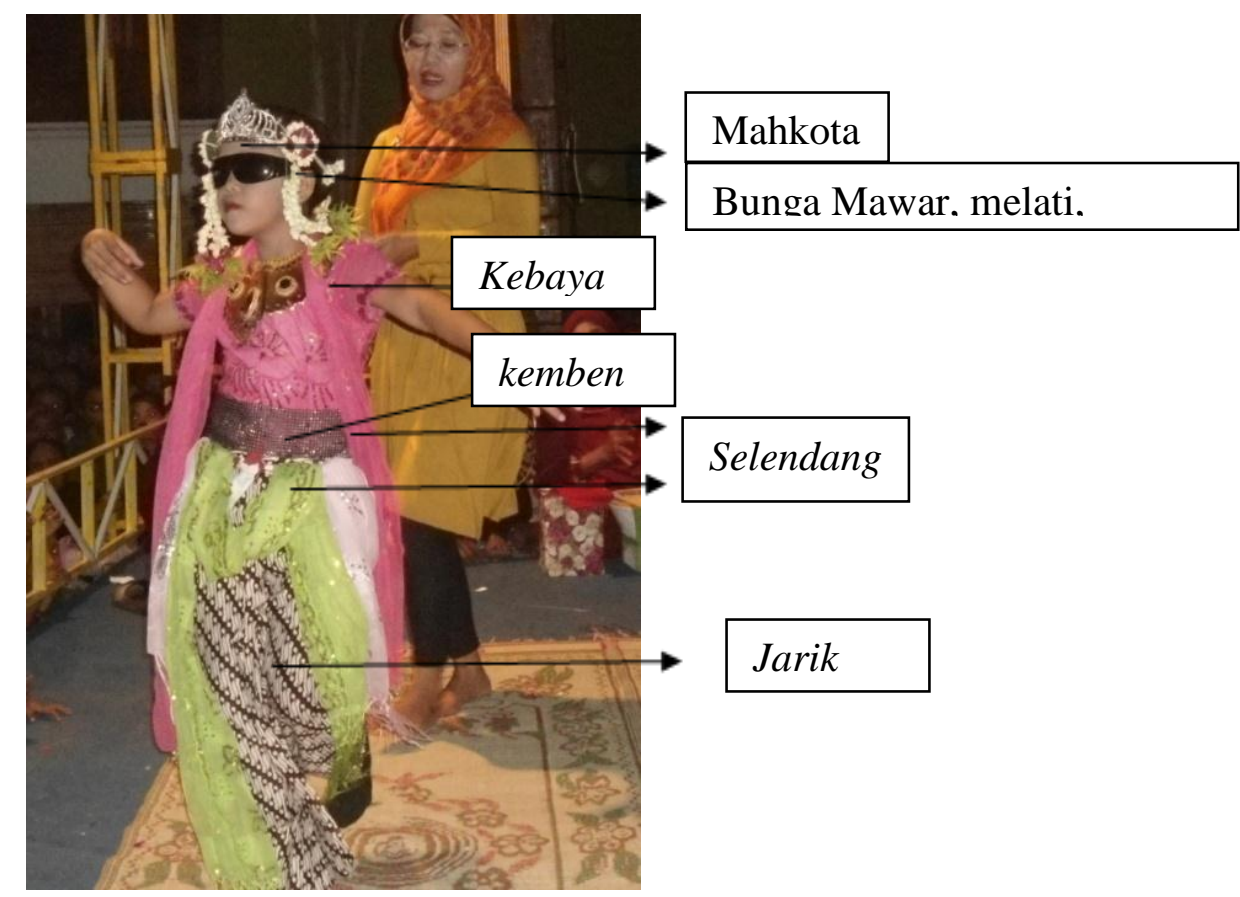

Foto 4.2 Busana Sintren Dangdut

(foto: Amalia Mega, Brebes April 2016) 


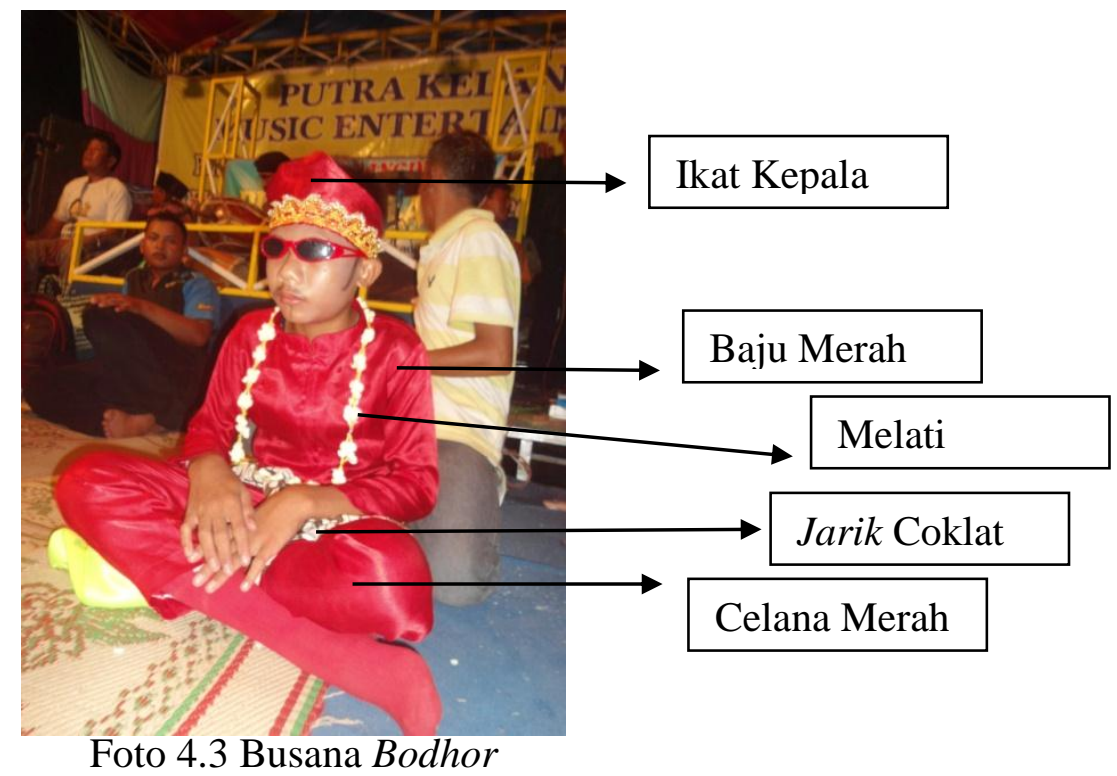

(foto: Amalia Mega, Brebes April 2016)

Warna busana yang digunakan penari bodhor dan kesenian Sintren Dangdut identik dengan warna busana yang menyolok. Penari bodhor menggunakan busana baju, celana dan ikat kepala berwarna merah menyimbolkan keberanian. Kain coklat menyimbolkan keagungan. Serta selendang berwarna biru menyimbolkan kesetiaan. Fungsi tata rias dan busana pada objek penelitian adalah untuk mendukung peranan yang ditampilkan, memperkuat dan menambah daya tarik pertunjukan kesenian Sintren Dangdut (wawancara Ibu Musdah, 16 April 2016).

\subsubsection{Tata Pentas}

Tata Pentas pada pertunjukan Sintren Dangdut tergantung waktu dan tempat acara pertunjukan diadakan. Sintren Dangdut masih tergolong kesenian tradisional kerakyatan, jadi kebanyakan dari kesenian tradisional kerakyatan dipergelarkan di lapangan terbuka. Sintren Dangdut juga masih sering dipentaskan di lapangan terbuka. Hanya saja pada acara hajatan seperti yang peneliti ambil 
tempat pentas diadakan pada panggung dikarenakan pertunjukan Dangdut lebih dominan dalam pertunjukan dan dikarenakan minat dari penanggap atau yang mempunyai hajat itu sendiri. Dalam panggung pertunjukan Sintren Dangdut sudah lebih modern dengan dilengkapinya lampu kerlap-kerlip seperti disko pada atas panggung. Tata pentas pertunjukan Sintren Dangdut lebih mengikuti minat masyarakat yang semakin modern ini (wawancara Bapak Dalang, 16 April 2016).

\subsubsection{Properti dan Sesaji}

Perlengkapan pertunjukan kesenian Sintren Dangdut harus dipersiapkan oleh seorang pawang. Perlengkapan yang dipersiapkan untuk dipakai adalah kurungan, kain penutup kurungan, layah atau anglo, dupa atau kemenyan, arang, sesaji, doa, alat musik iringan, tata rias busana.

\subsubsection{Kurungan}

‘Kurungan merupakan alat utama yang digunakan dalam pertunjukan kesenian Sintren Dangdut dan harus terbuat dari bambu, berukuran tinggi kurang lebih $120 \mathrm{~cm}$ dan lebar kurang lebih $100 \mathrm{~cm}$. Dari turun-temurun kesenian Sintren Dangdut ini memang diharuskan terbuat dari bambu, karena agar lebih mudah untuk diangkat. Dan kurungan yang terbuat dari bambu yang dianyam itu menyimbolkan rumah yang ditempati penari Sintren Dangdut. 


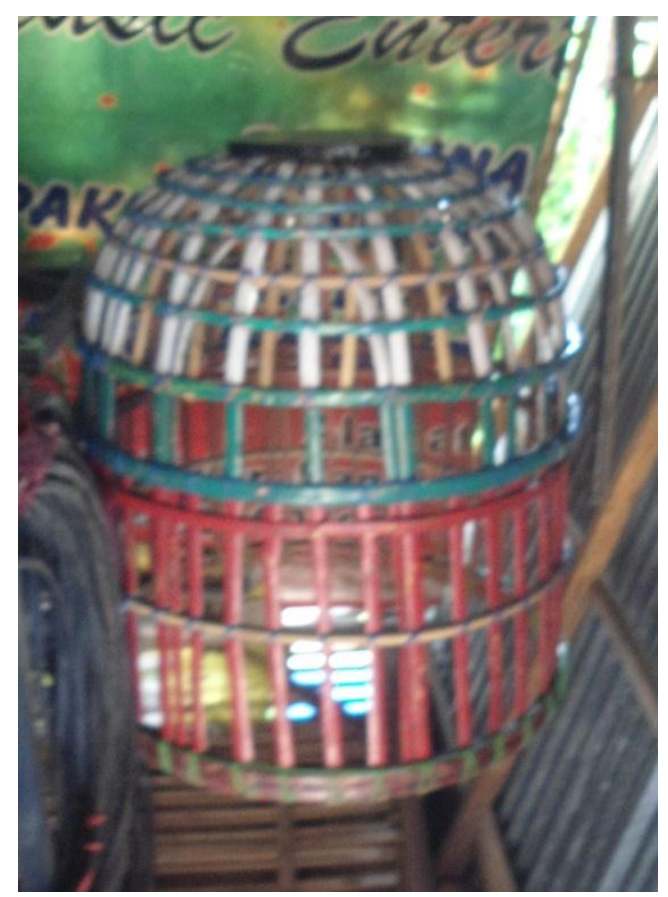

Foto 4.4 Kurungan Sintren

(dokumentasi: Amalia Mega, Brebes April 2016)

\subsubsection{Kain Penutup Kurungan}

Kain penutup kurungan digunakan untuk menutup kurungan, dan kain yang dipakai tidak diwajibkan pada warna tertentu, yang terpenting kain dapat menutup kurungan yang digunakan dalam pertunjukan kesenian Sintren Dangdut. Biasanya warna yang digunakan untuk kurungan adalah warna yang mencolok, agar mudah dilihat penonton saat pertunjukan. Kain penutup kurungan yang digunakan pada Grup kesenian Sintren Dangdut Putra Kelana ini kain polos berwarna merah cerah dan orange cerah ditambah putih sedikit dengan bahan dari katun. Simbol dari kain penutup ini adalah tertutup yang artinya menutup diri. 


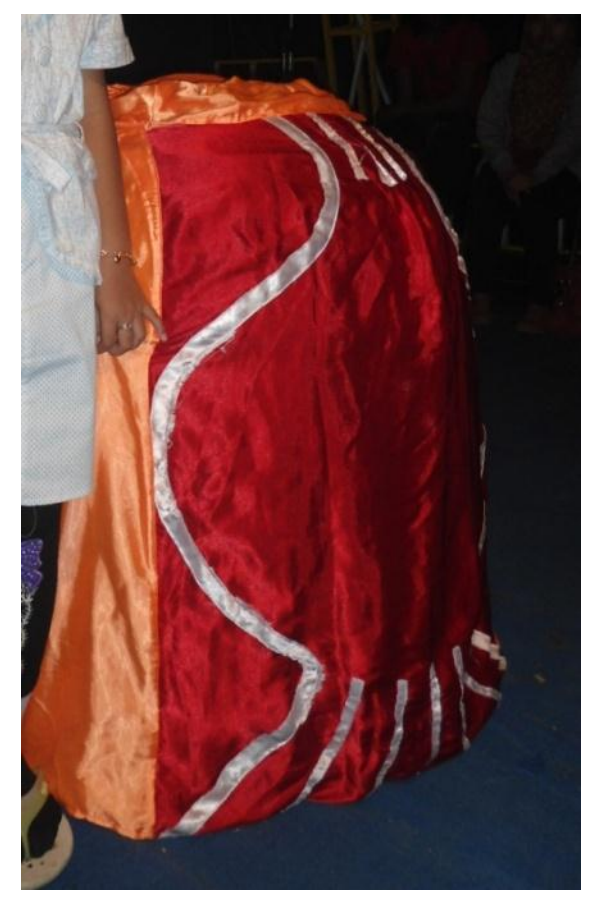

Foto 4.5 Kain Penutup Kurungan

(dokumentasi: Amalia Mega, Brebes Maret 2016)

\subsubsection{Layah atau Anglo}

Layah atau anglo yang digunakan dalam pertunjukan kesenian Sintren Dangdut harus terbuat dari tanah liat, berbentuk seperti gelas cangkir, dan bawahnya seperti layah untuk membuat sambal. Layah atau anglo yang terbuat dari tanah liat sebagai simbol agar pertunjukan kesenian Sintren Dangdut dapat menyatu dengan bumi. Layah atau anglo digunakan untuk tempat membakar kemenyan berupa dupa. 


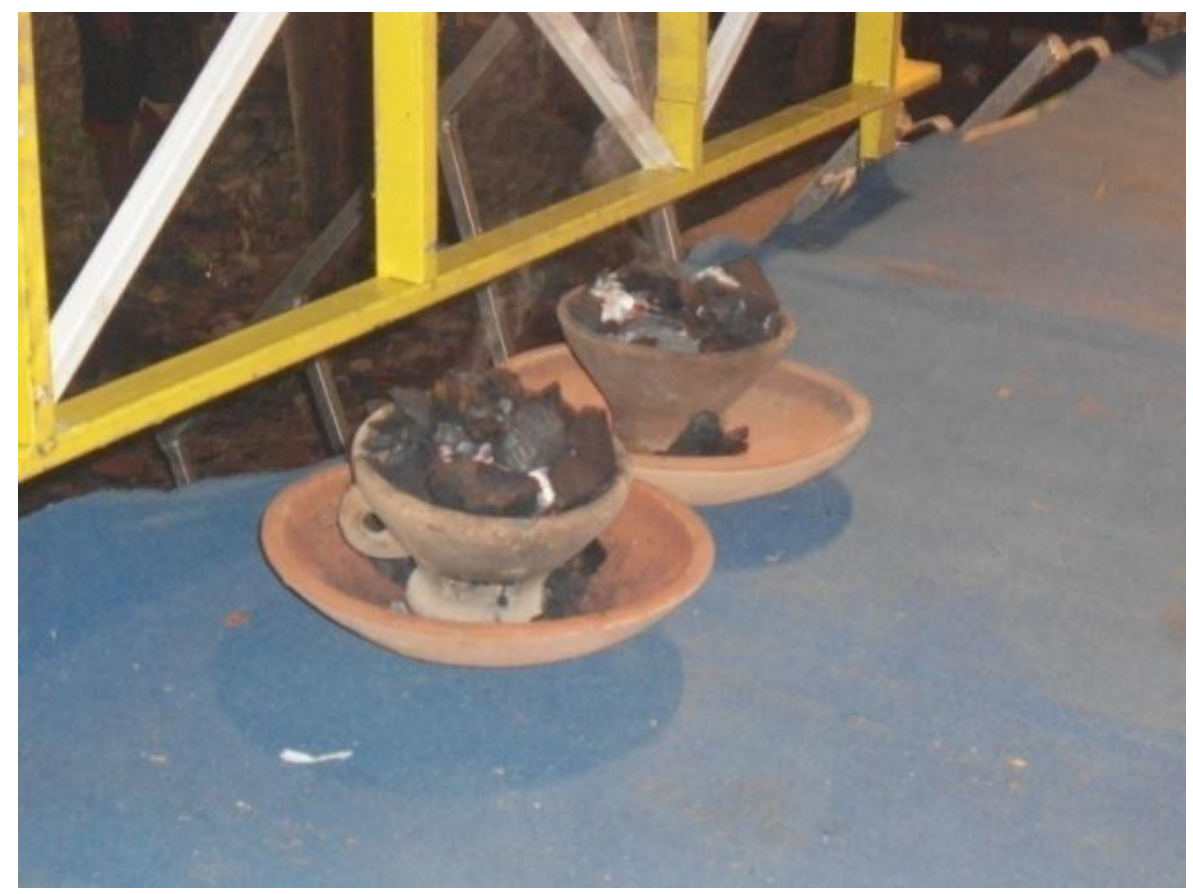

Foto 4.6 Layah atau Anglo

(dokumentasi: Amalia Mega, Brebes Maret 2016)

\subsubsection{Dupa atau Kemenyan}

Dupa atau kemenyan merupakan bahan yang dibakar agar mengeluarkan asap yang harum dan cepat mendatangkan roh halus (makhluk ghoib). Membakar dupa atau kemenyan pada saat pertunjukan kesenian Sintren Dangdut digunakan sebagai syarat untuk memanggil bidadari. Dupa atau kemenyan dapat digunakan untuk memanggil roh-roh dengan cara dibakar. Pada pertunjukan Sintren Dangdut bau dari asap pembakaran dupa atau kemenyan semacam penanda dimulainya pertunjukan kesenian Sintren Dangdut dan asap tersebut sebagai simbol mengundang agar sang Dewi-Dewi hadir untuk masuk kedalam raga penari Sintren Dangdut. 


\subsubsection{Arang}

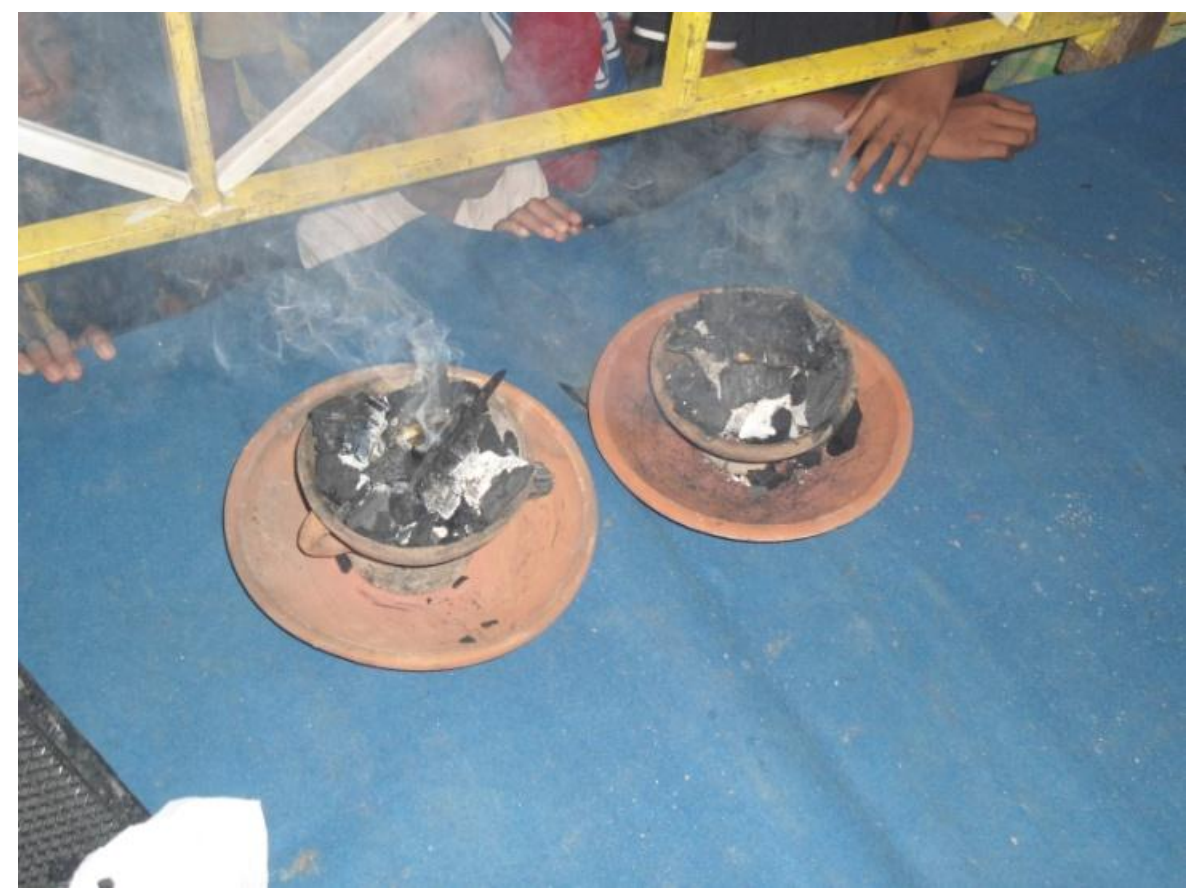

Foto 4.7 Arang pada pertunjukan Sintren Dangdut

(dokumentasi: Amalia Mega, Brebes Maret 2016)

Arang terbuat dari kayu yang dibakar dan menjadi hitam, digunakan sebagai sarana untuk membakar dupa agar dupa cepat mengeluarkan asap dan aroma yang harum, dari kepulan asap tersebut merupakan simbol agar lebih mempercepat datangnya roh halus (makhluk ghoib) yang diharapkan agarmemasuki raga atau tubuh penari Sintren Dangdut.

\subsubsection{Sesaji}

Sesaji dibuat sore saat malam akan mengadakan pertunjukan Sintren Dangdut. Pertunjukan Sintren Dangdut hanya digelar satu kali jika ada tanggapan. Berbeda dengan dahulu yang diadakan 7 hari berturut-turut. Pertunjukan Sintren sekarang ini lebih di ringkas dan disingkat karena minat masyarakat. Sesaji dibuat oleh para ibu-ibu rombongan grup Putra Kelana. 
Data yang diperoleh dari hasil wawancara 15 april 2016 dengan Bapak Dalang (pimpinan grup Putra Kelana), sesaji yang digunakan pada setiap pertunjukan kesenian Sintren dangdut adalah sebagai berikut:

(1) Pisang 7 rupa yang menyimbolkan hari itu ada tujuh dari senin sampai minggu.

(2) Juadah Pasar (pisang tujuh macam, konang ampo, suruh)

(3) Arang-arang nambang (rengginang diatas air).

(4) Sega liwet yang menyimbolkan agar arwah dewi-dewi merapat pada Sintren Dangdut.

(5) Telor ayam kampung yang menyimbolkan agar arwah bidadari merapat pada Sintren Dangdut.

(6) Tumpeng alus menyimbolkan kesucian pada diri Sintren Dangdut.

(7) Kembang telon (bunga mawar, bunga kenanga, bunga cempaka) menyimbolkan sebagai sara memanggil Dewi Rantamsari.

(8) Macam-macam Jajanan pasar seperti rengginang, kembang goyang, rempeyek, semprong mempunyai arti agar masyarakat Kelurahan Pasarbatang tetap merakyat dan sederhana.

(wawancara Ibu Musdah 20 April 2016) 


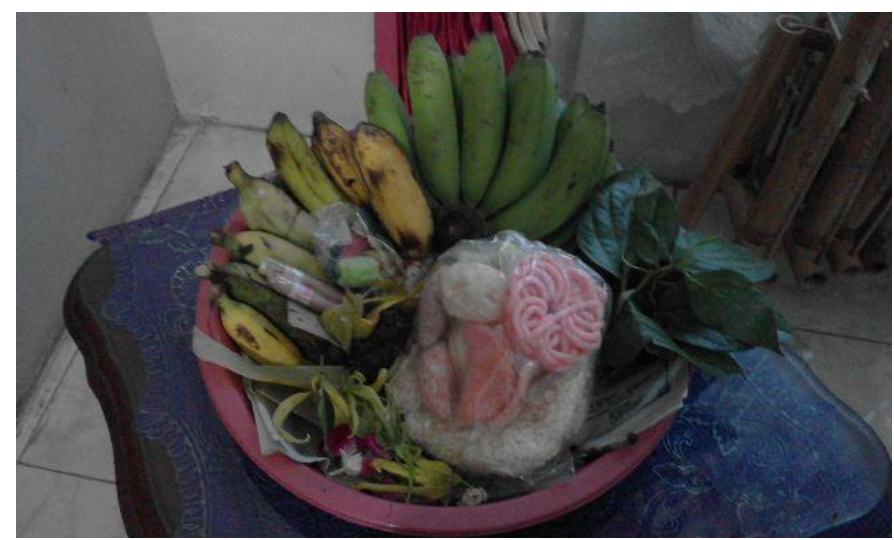

Foto 4.8 Sesaji Pada Pertunjukan Sintren

(Foto: Amalia Mega, Brebes Maret 2016)

\subsubsection{Doa}

Selain sesaji yang telah diuraikan diatas, hal yang terpenting dalam menjadikan penari Sintren Dangdut bisa menari karena kesurupan adalah mantra atau doa yang diucapkan oleh pawang Sintren. Ibu Musdah sebagai pawang Sintren Dangdut, (wawancara 15 April 2016), mengatakan:

"Aku wis puluhan tahun dadi pawang. Aku ana keturunan Sintren sing gemiyen nok.Biasane sedina sadurunge pentas Sintren Dangdut kue pawang puasa ben acara pentase lancar."

(aku sudah puluhan tahun jadi pawang. Aku ada keturunan Sintren dari dulu. Biasane sehari sebelum pentas Sintren Dangdut pawang puasa biar acara pentas lancar).

\subsubsection{Penonton}

Penonton pertunjukan Sintren Dangdut adalah orang yang melihat kesenian Sintren Dangdut yang terdiri dari seluruh warga Kelurahan Pasarbatang dan warga Kelurahan lain yang datang untuk melihat. Penonton pertunjukan kesenian Sintren Dangdut memposisikan dirinya disepanjang jalan dan memutari panggung Sintren Dangdut. Penonton pada pertunjukan kesenian Sintren Dangdut sangat diperlukan, karena pada urutan pertunjukan Sintren Dangdut melibatkan penonton terutama pada pertunjukan balangan, temoan, jual kembang, dan 
dangdutan. Dengan adanya penonton, Sintren Dangdut dapat berinteraksi dan saling membutuhkan satu sama lain (wawancara Bapak Dalang, 16 April 2016).

\subsubsection{Urutan Pertunjukan Kesenian Sintren Dangdut}

\subsubsection{Awal Pertunjukan}

Pertunjukan kesenian Sintren Dangdut dimulai dengan memainkan istrumen lagu-lagu Sintren untuk mengundang penonton bahwa pertunjukan Sintren Dangdut akan dimulai. Setelah instrumen lagu-lagu Sintren dilanjut dengan istrumen lagu-lagu Dangdut. Pada saat instrumen lagu-lagu pertama pawang menyediakan sesaji lengkap dan membakar kemenyan (dupa). Lalu Sintren Dangdut masuk kurungan, setelah asapnya mulai mengepul kemudian oleh pembawa dupa mengelilingi kurungan yang sudah dibalut dengan kain. Bapak Dalang pimpinan Grup Sintren Dangdut, (wawancara 16 April 2016), mengatakan:

"Pertunjukan Sintren Dangdut kue tampile jam 8 anjog jam 11 tok. Soale ijin polisi kue ora olih nganti jam 12 luwih, jare ganggu warga sing istirahat. Dadine biasane angger molor ya tetep jam 12 rampung."

(pertunjukan Sintren Dangdut itu tampil jam 8 sampai jam 11 saja. Karena ijin polisi itu tidak boleh sampai jam 12 lebih, katanya mengganggu warga yang istirahat. Jadi biasanya jika molor ya tetap jam 12 selesai.)

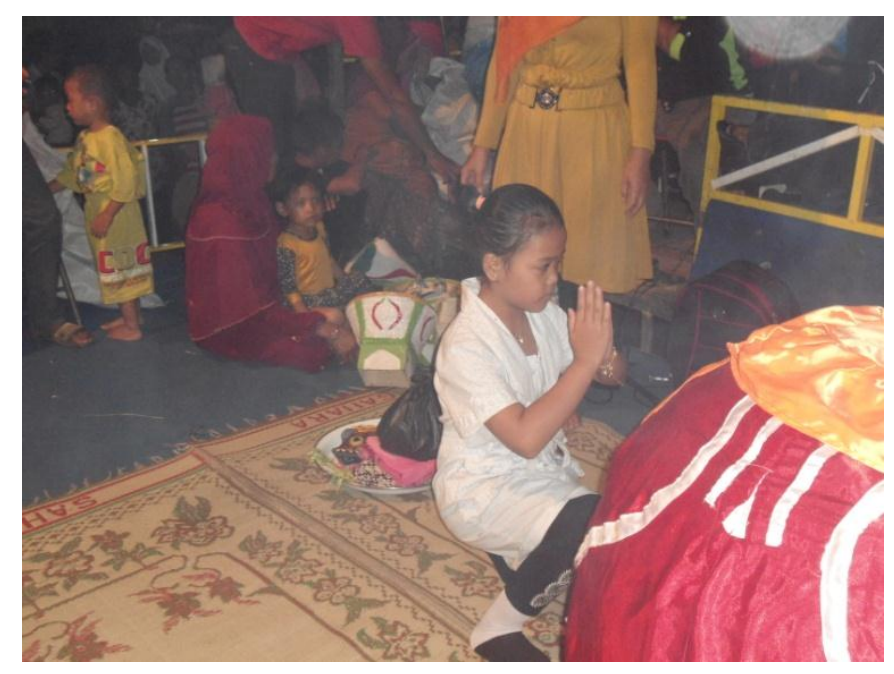




\section{Foto 4.9 Sintren Sebelum Memasuki Kurungan}

(foto: Amalia Mega, Brebes April 2016)

Pertunjukan kesenian Sintren Dangdut berlangsung dari jam 8 malam sampai jam 11 malam. Grup kesenian Sintren Dangdut Putra Kelana mendapatkan ijin dari Kepolisian tidak boleh mencapai dari jam 12 malam, karena mengganggu istirahat masyarakat setempat. Jika pertunjukannya mundur paling malam jam 12 malam sudah harus selesai. Selagi menunggu Sintren Dangdut dalam kurunngan, pada pertunjukan awal disambut oleh Sinden membawakan lagu Salam cipt. Grup Putra Kelana. Setelah asap mulai mengepul, nyanyian Sintren Dangdut mulai diperdengarkan sehingga mengundang perhatian penonton. Pada saat lagu-lagu ini diperdengarkan, Sintren Dangdut sudah berdandan rapi. Lagu-lagu yang dinyanyikan misalnya: Turun Sintren, Simbar Melati, Widadari. Nyanyiannyanyian tersebut mempunyai nilai bermacam-macam yang ditujukan bagi penonton pertunjukan kesenian Sintren Dangdut.

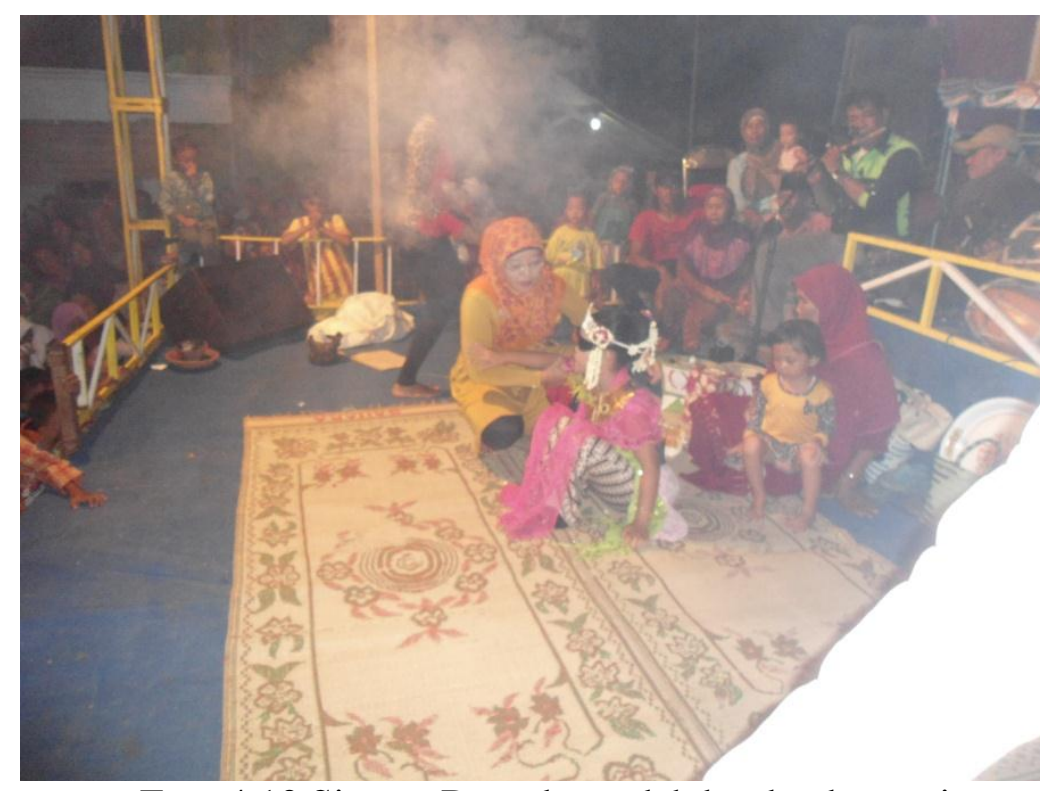

Foto 4.10 Sintren Dangdut sudah berdandan rapi

(foto: Amalia Mega, Brebes April 2016) 


\subsubsection{Bagian Pertunjukan}

Sebelum memasuki kurungan, Sintren Dangdut memberi hormat atau salam memutar menghadap depan, kiri, belakang serta kanan sambil jongkok. Setelah itu pawang memberikan pakaian, perlengkapan rias dan juga properti lainnya seperti roncean bunga melati mawar kenanga, kaca mata hitam, kaos kaki pada Sintren Dangdut sudah dipakai, selendang dan sebagainya. Sambil menunggu Sintren dangdut merias dirinya, tembang Dangdut dinyanyikan sebagai tembang pembuka.

Setelah bidadari datang, pelaku utama (Sintren Dangdut) memberitahu penjaga Sintren atau pawang dengan memberi isyarat kurungan digerak-gerakan. Apabila kurungan bergerak-gerak, merupakan pertanda pelaku Sintren dangdut sudah mulai intrance (kesurupan), maka kurungan segera dibuka dalam keadaan mata terpejam dan Sintren Dangdut memakai kacamata. Kemudian Sintren berdiri, baju dirapikan oleh pawang Sintren Dangdut. Setelah merapikan baju sebentar, Sintren Dangdut langsung menari-nari dan memutari panggung.

Gerakan tari yang dilakukan oleh Sintren Dangdut bukan atas kemauannya sendiri, melainkan karena adanya roh bidadari (makhluk ghaib) yang memasuki tubuhnya. Gerak yang ditarikan oleh penari pada saat pertunjukan kesenian Sintren Dangdut antara lain sembahan duduk, sembahan berdiri, gerak kaki berjingkat-jingkat, pinggul bergoyang, tangan ukel seblak sampur, kepala melenggak-lenggok. Tidak ada pola gerakan yang digarap pada saat sebelum pertunjukan dimulai. Jadi gerakan yang dilakukan hanya berulang-ulang 
(monoton) tidak ada patokan yang membatasi dalam bergerak. Lincah dan tidaknya gerakan yang ditarikan oleh penari Sintren Dangdut tergantung dari roh yang merasukinya. Jika pada saat dangdutan, Sintren Dangdut juga menari dengan pinggul bergoyang. Setelah dianggap cukup dinikmati oleh penonton, Sintren Dangdut dimasukan lagi dalam kurungan sebagai pergantian tembang atau nyanyian.

Pada pertunjukan selanjutnya sintren Dangdut di temani oleh bodhor yang merupakan pasangan Sintren Dangdut dan lebih memeriahkan pertunjukan. Pertunjukan Sintren Dangdut mempunyai beberapa atraksi yang sudah berurutan. Bagian pertunjukan yang biasa ditampilkan pada kesenian Sintren Dangdut antara lain:

\subsection{Balangan}

Balangan adalah kegiatan melempar atau mbalang sesuatu benda kearah penari Sintren Dangdut oleh penonton. Biasanya benda yang dilempar yaitu baju atau benda yang berupa kain. Pada atraksi balangan lagu yang dinyanyikan yaitu "Widadari" yang dinyanyikan terus menerus sampai atraksi balangan selesai dan penonton yang melempar benda kepada Sintren dangdut telah dikembalikan kainnya. Menurut mitos, jika kain yang mbalang mengenai tubuh Sintren Dangdut, nantinya kain tersebut kembali kepemiliknya berbau wangi. 


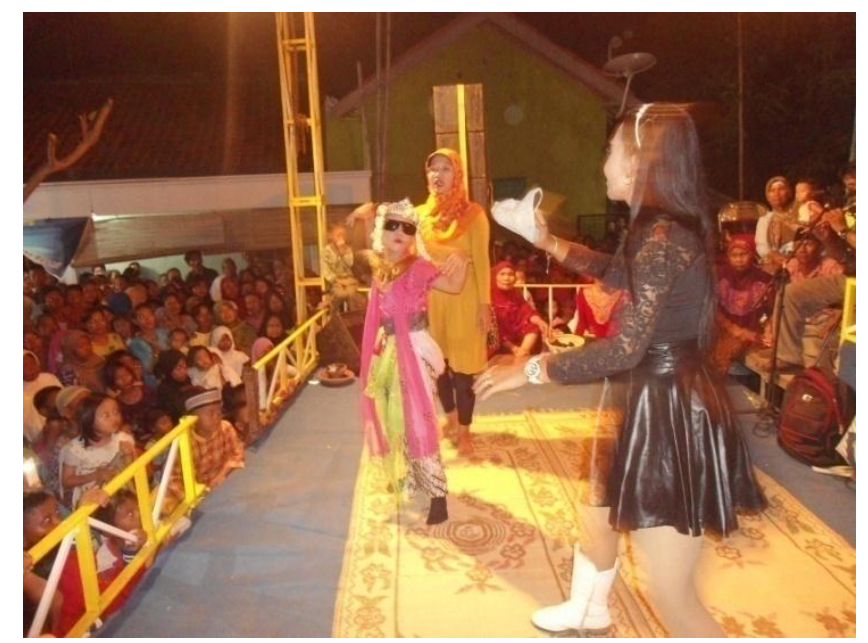

Foto 4.11 Adegan Balangan

(foto: Amalia Mega, Brebes April 2016)

Saat penonton mbalang kain tersebut biasanya diselipkan uang untuk Sintren Dangdut. Pada saat adegan balangan sebagai simbol pengharapan, karena bagi penonton yang membalang sebagaian besarmemiliki keinginan untuk dirinya sendiri. Setelah dianggap cukup memuaskan penonton, Sintren dangdut masuk kembali ke dalam kurungan.

\subsection{Bodhor}

Bodhor adalah penari pendamping Sintren Dangdut. Saat tembang "Jamang Topi" di nyanyikan, penari Sintren Dangdut mencari bodhor dengan mengelilingi panggung. Setelah itu bodhor keluar dari belakang panggung dengan sudah intrance (kesurupan). Penari bodhor diibaratkan Ki Bahurekso yang dicari oleh Dewi Rantamsari yaitu Sintren Dangdut. Sintren dan bodhor menari bersama-sama tetapi masih bersebelahan (belum berinteraksi). Dan tetap pada adegan balangan dengan Sintren Dangdut dan bodhor 


\subsection{Temoan}

Temoan adalah kegiatan Sintren Dangdut membawa nampan atau tampah atau besek dibantu oleh pawang berjalan mengitari penonton kadang-kadang sampai keluar dari area pentas/panggung untuk meminta sokongan atau sumbangan seikhlasnya, diiringi tembang "Kembang Mawar" berulang-ulang sampai selesai. Pada saat temoan, penari bodhorpun membantu Sintren meminta sumbangan keluar arena pentas/panggung.

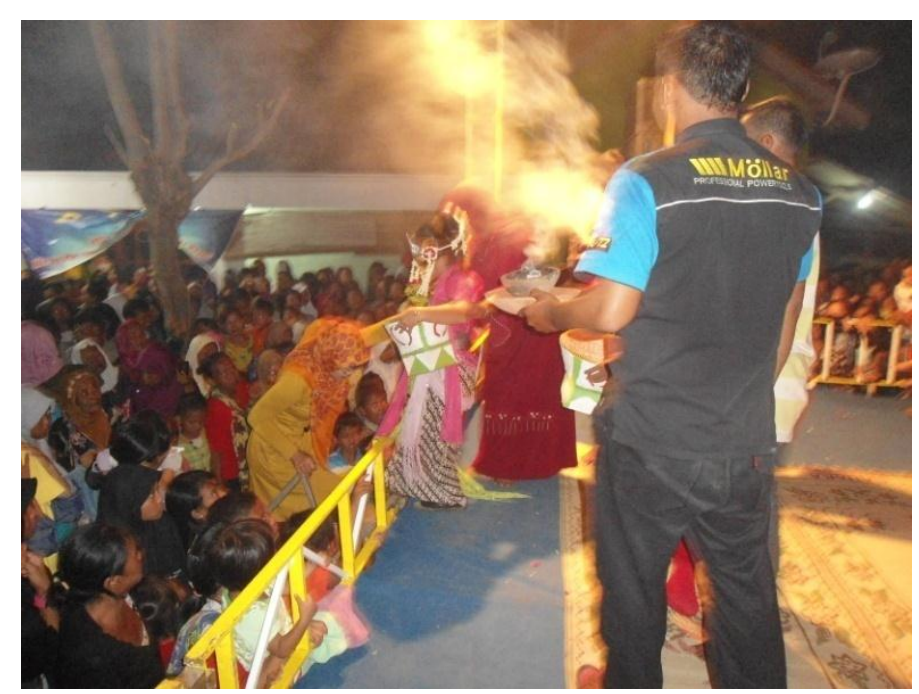

Foto 4.12 Sintren Dangdut Meminta Temoan (foto: Amalia Mega, Brebes April 2016)

Pada saat temoan ini menyimbolkan keikhlasan warga Kelurahan

Pasarbatang, karena pada saat adegan temoan mereka rela memberikan uang dengan ikhlas untuk anggota Sintren Dangdut grup Putra Kelana.

\subsection{Dangdut}

Dangdut merupakan selingan pada pertunjukan Sintren Dangdut ini. Saat Sintren Dangdut dan bodhor masih meminta temoan pada penonton diluar area pentas, musik dangdut dinyanyikan oleh biduan di dalam area pentas. Musik dangdut yang dimainkan berjudul bebas, biasanya reques dari pemilik hajatan 
ataupun tamu undangan yang hadir pada hajatan tersebut. Musik dangdut yang nyanyikan seperti yang berjudul "Ada Rindu", setelah Sintren Dangdut dan bodhor telah selesai meminta temoan.

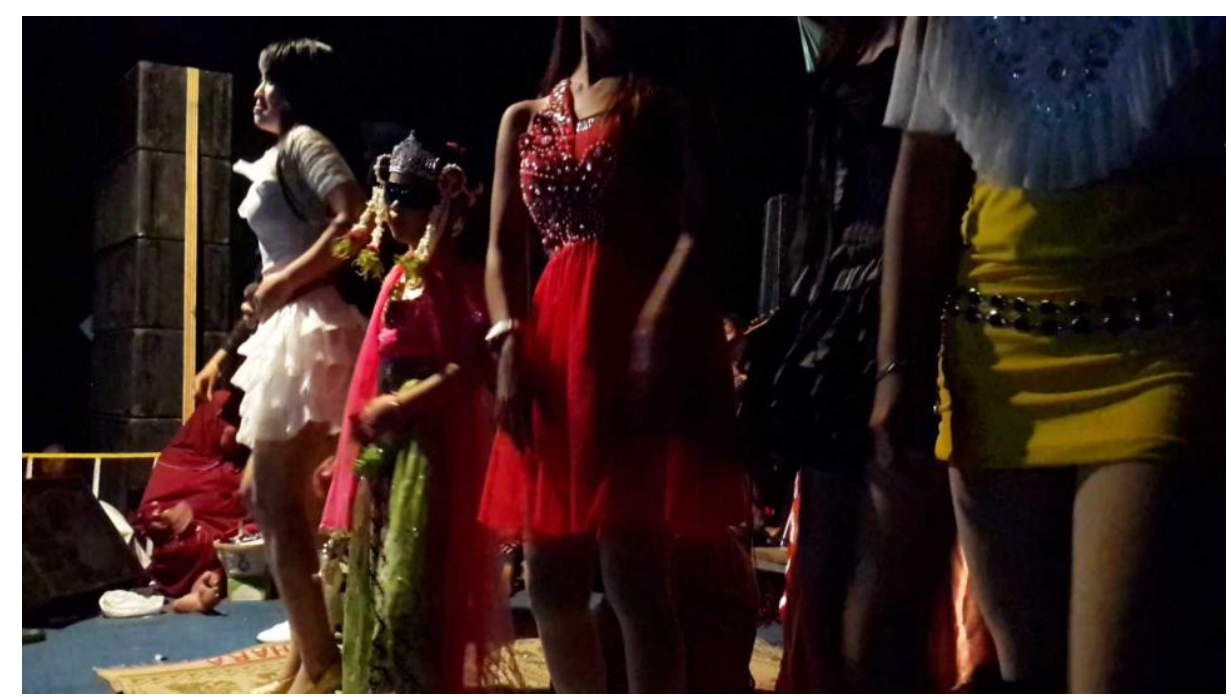

Foto 4.13 Sintren Dangdut saat Menari dengan Biduan Musik Dangdut (foto: Amalia Mega, Brebes April 2016)

Sintren Dangdut dan bodhor memasuki area pentas/panggung lalu ikut menari dengan biduan yang diiringi musik dangdut. Setelah musik dangdut selesai, Sintren Dangdut memasuki kurungan kembali dan bodhor disebelah kurungan Sintren Dangdut duduk bersila.

\subsection{Jual Kembang}

Jual kembang merupakan adegan saat Sintren Dangdut dan bodhor menjual kembang melati. Pada saat itu penonton bisa membelinya. Kembang melati yang dijual oleh Sintren Dangdut dan bodhor adalah kembang pengasihan. 


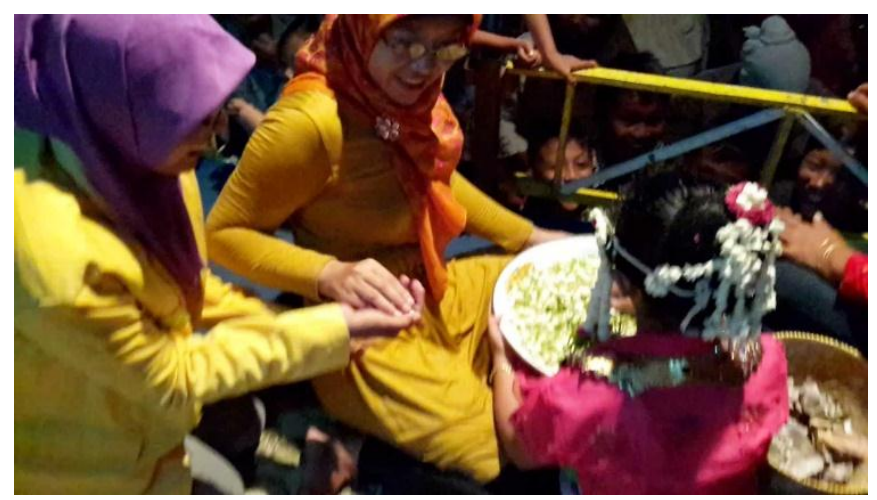

Foto 4.14 Sintren Dangdut dan bodhor menjual kembang melati (foto: Rani, Brebes April 2016)

\subsection{Dangdut}

Dangdut disini juga sebagi selingan pertunjukan kesenian Sintren Dangdut. Sintren Dangdut dan bodhor menjual kembang biasanya sampai keluar area pentas/panggung, dan pada saat keluar area pentas musik dangdut dinyanyikan. Setelah jual kembang melati yang dipercaya sebagai pengasihan telah habis. Sintren Dangdut dan bodhor kembali ke area pentas/panggung. Kemudian Sintren Dangdut dan bodhor menari bersama biduan yang bernyanyi. Setelah satu lagu selesai, Sintren dangdut kembali memasuki kurungan dan bodhor berada disamping kurungan Sintren Dangdut duduk bersila.

\subsection{Sintren dan Bodhor Bertani}

Pada saat tembang "Bapak Tani” diartikan sebagai adegan sebuah rumah tangga yang rukun. Sintren Dangdut sebagai istri dari bodhor membantu pekerjaan bodhor di sawah, dan menyiapkan makan untuk bodhor setelah bekerja. Rasa lelah letih bercampur jadi satu yang dirasakan suami istri tersebut yang diibaratkan, tetapi mereka berdua tetap rukun. Adegan ini menyimbolkan agar masyarakat Kelurahan Pasarbatang tidak malas untuk bekerja sebagai buruh tani karena dari bertani kita dapat memakan hasil pertaniannya. 


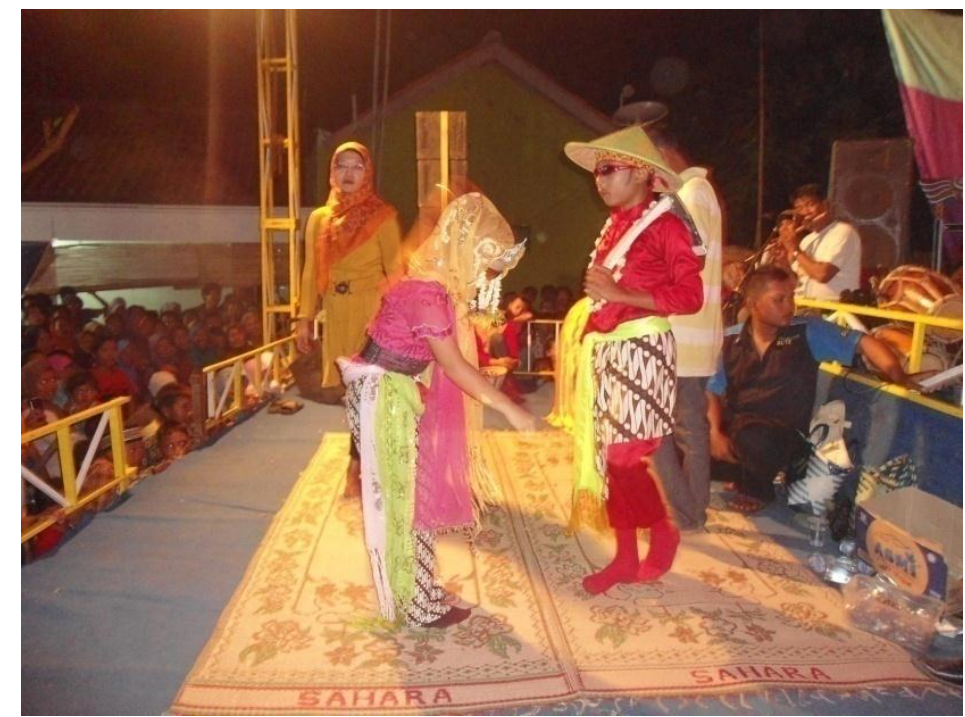

Foto 4.15 Sintren Dangdut dan Bodhor sedang Bertani (foto: Amalia Mega, Brebes April 2016)

Setelah bertani selesai dan menyantap makanan Sintren Dangdut untuk bodhor. Sintren Dangdut kembali masuk kurungan untuk berganti baju kembali baju yang kedua. Sedangkan bodhor tetap duduk bersila disebelah kurungan Sintren Dangdut.

\subsection{Dangdut}

Selagi menunggu Sintren Dangdut berganti baju yang kedua, pertunjukan kesenian Sintren ini diselingi oleh dangdut. Jadi perhatian penonton tidak pada kurungan, tetapi kepada biduan yang menyanyikan lagu dangdut. Dengan demikian masyarakat yang menonton tidak bosan atau jenuh melihat pertunjukan ini. Selingan dangdut pada waktu ini ada dua nyanyian dangdut yang dinyanyikan oleh biduan.

\subsection{Ciri Khas Sintren Dangdut (Umbul-Umbul)}

Ciri khas kesenian Sintren Dangdut yang lainnya yaitu pada tembang “Umbul-Umbul”. Pada tembang umbul-umbul Sintren keluar dari kurungan sudah 
berganti baju dan memakai bawahan celana yang dibuat seperti rok pendek. Pada adegan ini Sintren Dangdut dan bodhor menari ke kanan dan kekiri menggunakan sapu tangan di kedua tangannya. Kedua tangan mereka yang dililitkan sapu tangan di letakkan di samping telingan kanan dan kiri, kepala mereka seperti tina toon ke kanan dan kekiri. Dan ditambah gerakan pinggul mereka yang berputar. Kadang Sintren Dangdut dan bodhor saling berhadapan dan saling menghadap belakang masing-masing. Sintren Dangdut dan bodhror berputar arah hadap sehingga semua penonton melihat adegan ini dengan jelas.

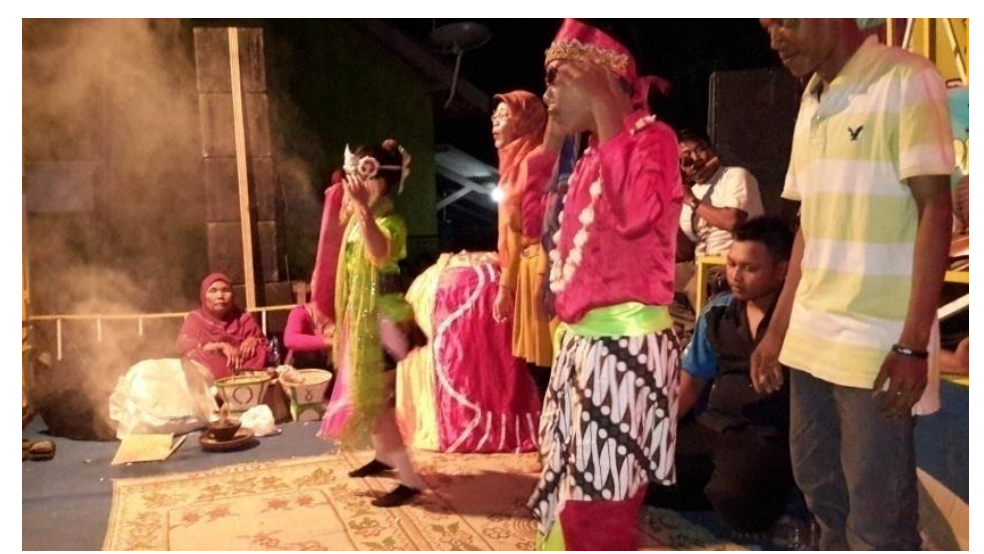

Foto 4.16 Adegan Umbul-Umbul

(foto: Amalia Mega, Brebes April 2016)

\subsection{Naik Kurungan}

Naik kurungan adalah salah satu ciri khas atau atraksi dalam pertunjukan kesenian Sintren Dangdut. Adegan ini adalah adegan dimana Sintren Dangdut dan bodhor naik kurungan dari mulai satu persatu sampai dua-duanya menaiki kurungan bersama. Sintren Dangdut dan bodhor naik kurungan dibantu dengan pawang. Pada saat diatas kurungan, Sintren Dangdut dan bodhor atraksi memainkan pinggul mereka agar penonton terhibur, sedangkan jika masih 
dipanggung, Sintren Dangdut maupun bodhro memutari kurungan yang berada ditengah panggung.

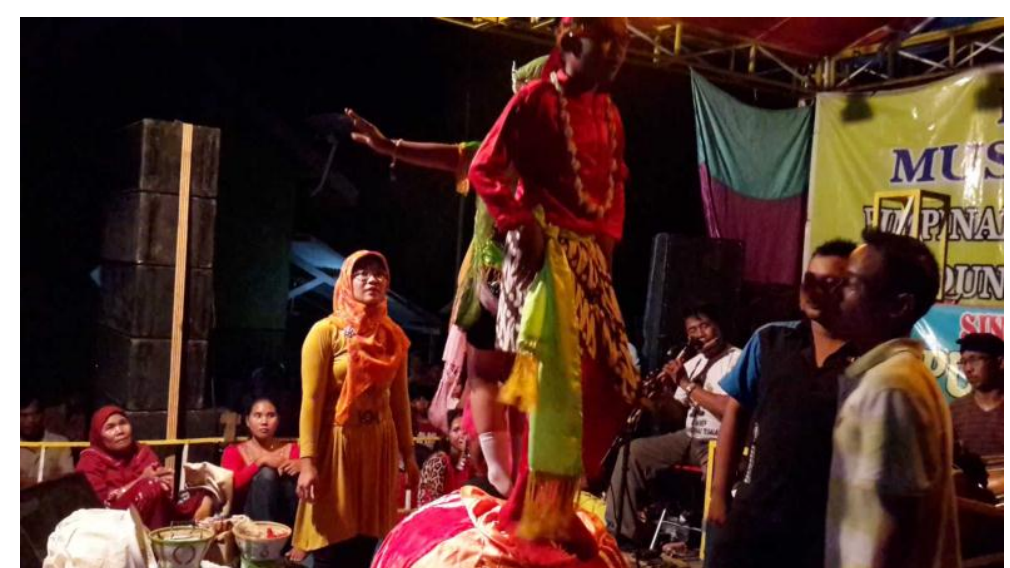

Foto 4.17 Atraksi Sintren Dangdut dan Bodhor Naik Kurungan (foto: Amalia Mega, Brebes April 2016)

Kesenian Sintren Dangdut semula hanyalah sebagai sarana upacara adat atau keagamaan, namun kemudian semata-mata sebagai hiburan saja seperti pada acara hajatan, apalagi dengan ditambahkannya musik dangdut ke dalam pertunjukan kesenian Sintren Dangdut, hal ini merupakan gejala yang umum pada kesenian tradisional karena majunya perkembangan zaman.

\subsubsection{Akhir Pertunjukan}

Pada akhir pertunjukan Sintren Dangdut ada tembang yang berjudul “Tangis-tangis Layung” dan setelah adegan itu dilanjut dengan dangdutan.

\subsection{Tangis-tangis layung}

Tangis-tangis layung merupakan adegan dimana penari Sintren akan dimasukan ke kurungan dan akan disadarkan kembali, dan bodhor menangis akan meninggalkan Sintren Dangdut. Adegan ini menyimbolkan agar setan yang sudah 
jadi arwah agar tidak mengganggu manusia yang masih hidup di dunia. Setelah bodhor menangis, bodhor disadarkan kembali oleh pawang.

\subsection{Dangdutan}

Setelah Sintren Dangdut kembali dibuka kurungannya dan kembali berpakaian seperti semula, Sintren Dangdut sadar. Setelah itu biduan menghibur masyarakat Kelurahan Pasarbatang dengan menyanyikan beberapa lagu dangdut. lagu dangdut yang dinyanyikan oleh biduan terserah dengan minat masyarakat. Selagi biduan menyanyikan lagu dangdut, ada beberapa masyarakat yang ikut menari bersama biduan dan menyawernya, ini disebut dengan tradisi saweran. Tetapi pertunjukan hanya dilaksanakan sampai jam 12 malam, tidak melebihi jam 12 malam karena ijin dari Kepolisian sampai jam 12 malam.

\subsection{Upaya Pelestarian Seni Tradisi Dalam Bentuk Pertunjukan Kesenian Sintren Dangdut Grup Putra Kelana di Kelurahan Pasarbatang Kabupaten Brebes}

Jalan yang ditempuh untuk menarik perhatian selera penonton kepada seni pertunjukan tradisi. Di antaranya dengan melakukan upaya kreatif dan inovatif dari segi kesenian tradisi itu sendiri, dari penggarapan aspek ceritanya, diselaraskan sesuai konteks zaman, penggarapan kreatifnya mesti lebih dramatik dan menghibur, peningkatan kualitas kinerja para pekerja seni (pelaku, pemusik, teknologi pementasan dimodernisasi).

Berdasarkan temuan data di lapangan dapat dikemukakan bahwa dalam seni pertunjukan Sintren Dangdut Grup Putra Kelana di Kelurahan Pasarbatang Kabupaten Brebes, sudah dilakukan langkah-langkah pelestarian dengan beberapa karya inovatif sebagai berikut: 
Kesenian Sintren Dangdut grup Putra kelana sudah mengemas secara singkat pertunjukannya. Dahulu pertunjukan 5 jam lebih, sekarang menjadi 2-3 jam saja. Dengan mengemas pertunjukan bukan berarti menghilangkan nilai estetika yang ada, kesenian Sintren dangdut masih dengan rasionalitas seni tradisi yang melekat di kesenian Sintren.

Memberikan kesan menarik dalam kesenian Sintren dilakukan dengan mengubah instrumen musik dari gamelan menjadi instrumen musik modern yang sudah tidak memakai gamelan lengkap lagi. Memadukan iringan dengan lagu-lagu dangdut dan sentuhan biduan yang berpenampilan sudah modern.

Grup Putra Kelana sudah menerapkan manajemen profesional dalam pementasan seni pertunjukan kesenian Sintren Dangdut. Sudah diberlakukan manajemen pementasan seni pertunjukan kesenian Sintren Dangdut yang mengedepankan profesionalitas, baik dalam bermain (para pekerja seni), pengelolaan promosi, kerja sama dengan pihak-pihak terkait, hingga pengelolaan keuangan.

Upaya pelestarian seni tradisi dalam bentuk pertunjukan kesenian Sintren Dangdut Grup Putra Kelana ini dibagi menjadi bentuk perlindungan seni tradisi, bentuk pengembangan, dan bentuk pemanfaatannya. Dalam pertunjukan Sintren yang biasa saja menjadikan masyarakat mulai bosan dan jenuh. Grup Putra Kelana ini berpikir agar kesenian Sintren tetap berkembang tetapi dengan pengembangan agar masyarakat tetap berminat dengan pertunjukan kesenian Sintren Dangdut. Akhirnya dengan minat masyarakat yang begitu besarnya dengan Dangdut, pada Grup Putra Kelana memodifikasikan kesenian Sintren dengan musik dangdut. 
Bentuk perlindungan, pengembangan, dan pemanfaatan lebih rinci lagi dibahas antara lain:

\subsubsection{Bentuk Perlindungan}

Kesenian tradisional kerakyatan termasuk kesenian Sintren Dangdut perlu adanya perlindungan dari pemerintah maupun kelompok seni dan masyarakat agar kesenian tradisional Sintren Dangdut tidak punah. Kesenian Sintren Dangdut salah satu asset daerah harus dilestarikan, dengan pelestarian itu pasti diadakannya perlindungan agar terus berkembang. Perlindungan yang dapat di tempuh dalam kesenian Sintren Dangdut menurut Bapak Dalang (Pimpinan Grup Putra Kelana), wawancara 16 April 2016, antara lain:

1) Hukum

Perlindungan dari badan hukum sangat dibutuhkan karena dengan adanya hukum yang melindungi kesenian tradisional tidak akan ada yang merebut kesenian tradisional itu termasuk kesenian tradisional Sintren Dangdut. Pada kesenian Sintren Dangdut Grup Putra Kelana telah dilindungi oleh Polres Kabupaten Brebes dan didukung penuh oleh pemerintah daerah. Jadi upaya perlindungan sudah ada pada kesenian Sintren Dangdut Grup Putra Kelana. Bapak Dalang pimpinan Grup Putra Kelana, (wawancara 16 April 2016), mengatakan:

"Grup kiye wis ada pelindung sing pilres brebes nok, dadi wis ora usah khawatir pentas mana mene. Tapi jam pentas kue dibatesi ora olih luwih nganti jam 12 bengi."

(Grup ini sudah ada pelindung dari Polres Kabupaten Brebes, jadi tidak perlu khawatir pentas kesana-kesini. Tetapi jam pentas di batasi, tidak boleh melebihi jam 12 malam.) 
2) Dokumentasi

Selain perlindungan hukum, perlindungan pendokumentasian sangat penting dikarenakan jika dokumentasi itu tersimpn rapih, maka kesenian Sintren Dangdut terlindung bentuk pertunjukannya. Kesenian Sintren Dangdut Grup Putra Kelana selama pementasan selalu di dokumentasikan sebagai arsip seseorang yang menanggap maupun arsip Grup Putra Kelana. Bapak Dalang Pimpinan Grup Putra Kelana, (wawancara 16 April 2016), mengatakan:

"Tiap pentas mana mene grup kiye selalu di dokumentasikan nok, mbuh mengko nggo arsip wong hajatan karo arsip kelompok grup kiye. Ya termasuk bisa nggo melindungi bentuk pertunjukane”

(Setiap pertunjukan kesana-kesini grup ini selalu mendokumentasikan, apa nanti untuk arsip orang hajatan atau arsip kelompok kesenian Grup ini. Termasuk bisa untuk melindungi bentuk pertunjukannya.)

3) Fasilitas

Perlindungan pada fasilitas pertunjukan juga sangat penting. Kesenian tradisional jika dipentaskan juga membutuhkan fasilitas tempat pentas, perlengkapan pertunjukan, juga fasilitas untuk diskusi masalah kesenian. Grup Putra Kelana melindungi perlengkapan pertunjukan, dan juga fasilitas untuk berdiskusi. Bapak Dalang Pimpinan Grup Putra Kelana, (wawancara 16 April 2016), mengatakan:

"Fasilitas grup kiye wis tak penuhi mipil nok, kue ya termasuk upaya pelestarian grup kiye nggo kesenian tradisi. Angger diskusi masalah kesenian termasuk Sintren Dangdut ya ning umahe aku, umahe aku terbuka nggo sapa bae diskusi."

(Fasilitas Grup ini sudah saya penuhi, itu termasuk upaya pelestarian dalam perlindungan Grup untuk kesenian tradisi. Jika diskusi masalah kesenian termasuk Sintren Dangdut ya dirumah saya, rumah saya terbuka untuk siapa saja berdiskusi.) 


\subsubsection{Bentuk Pengembangan}

Pengembangan dalam kesenian tradisional kerakyatan tidaklah mudah. Masyarakat setempat mengembangkan seni kerakyatan yang sudah lama tumbuh dalam kebiasaan dan di kembangkan kembali berkreasi berinovasi kembali. Jadi para kelompok seni, masyarakat bekerja sama dalam pengembangan untuk pelestarian kesenian tradisional. Pengembangan yang ditempuh dalam bentuk pertunjukan kesenian Sintren Dangdut yaitu:

1) Diskusi

Pelestarian seni tradisi termasuk kesenian Sintren Dangdut terus dikembangkan dengan berdiskusi dengan masyarakat sekitar. Pengembangan yang dilakukan pada Sintren Dangdut yaitu mengemas kembali bentuk pertunjukan dengan kebanyakan minat masyarakat sekarang ini. Minat masyarakat sekarang ini lebih pada musik dangdut, jadi kesenian Sintren dikembangkan dan dipadukan dengan dangdut sehingga pada pertunjukannya dinamakan Sintren Dangdut. Bapak Dalang pimpinan Grup Putra Kelana, (wawancara 16 April 2016), mengatakan:

"Gemiyen kelompok kesenian Bapak kue Sintren tok laka dangdute, terus masyarakat mulai bosen, terus diskusi masyarakat lebih minat karo music dangdut. Terus Bapak ndue ide, kesenian Sintren di gabung karo Dangdut dadi kesenian Sintren Dangdut."

(Dahulu kelompok kesenian Bapak hanya Sintren saja tidak ada dangdut, kemudian masyrakat mulai bosan, dan diskusi masyarakat lebih minat ke music dangdutnya. Dari situ Bapak mempunyai ide kalua kesenian Sintren digabung dengan dangdut jadi kesenian Sintren Dangdut.) 
2) Fasilitas

Bentuk pengembangan pada fasilitas terlihat jelas tata panggung saat pementasan. Banyak pengembangan fasilitas maupun perlengkapan pertunjukan pada Sintren Dangdut. Mulai dari perlengkapan pertunjukan yang sudah diberi warna-warni bergambar kemudian pakaian Sintren Dangdut, Kain Penutup Kurungan yang sudah lebih modern dengan kain mengkilap. Pengembangan fasilitas pementasan dengan lampu kerlap-kerlip, penempatan alat music atau tata panggung sudah ada perkembangan dari dahulu. Bapak Dalang pimpinan Grup Putra Kelana, (wawancara 17 April 2016), mengatakan:

"Pengembangan fasilitas kue kaya tempat pentas nok wis nang panggung, terus perlengkapan pertunjukan kaya tampah wis di gambar warna-warni."

(Pengembangan fasilitas itu seperti tempat pementasan sudah diatas panggung, kemudian perlengkapan pertunjukan seperti tampah sudah di gambar berwarna-warni.)

3) Kreasi Baru dan Inovasi

Pengembangan kreasi baru dan inovasi pada urutan pertunjukan, bentuk pertunjukan Sintren Dangdut. Walaupun kesenian Sintren Dangdut masih sacral dan tidak banyak berubah tetapi digabungkan dengan music dangdut sudah cukup merupakan kreasi baru dari kesenian tradisional kerakyatan. Kesenian Sintren Dangdut tampil mengikuti minat masyarakat, dan tidak berubah dari ciri khas kesenian itu sendiri. Bapak Dalang pimpinan Grup Putra Kelana, (wawancara 17 April 2016), mengatakan: 
"Pengembangan gabungan kue ya termasuk kreasi baru dan inovasi sing kerenian rakyat. Dadi kesenian kue berkembang ngikuti minat masyarakat tapi ora melenceng karo ciri khas kesenian kue."

(Pengembangan gabungan itu termasuk kreasi baru dan inovasi dari kesenian rakyat. Jadi kesenian itu berkembang mengikuti minat masyarakat tetapi tidak melenceng dari ciri khas kesenian itu sendiri.)

\subsubsection{Bentuk Pemanfaatan}

Perlindungan dan pengembangan itu pasti mempunyai tujuan manfaat dari kesenian tradisional kerakyatan termasuk Sintren Dangdut. Bentuk pemanfaatan mengemas dari perlindungan kesenian kemudian dari pengembangan kesenian setelah itu dari perlindungan dan pengembangan munculah pemanfaatannya. Pemanfaatan kesenian tradisional Sintren Dangdut antara lain:

1) Pendidikan

Pemanfaatan dari segi pendidikan bisa dari terstruktur maupun tidak terstruktur, formal maupun tidak formal atau pendidikan masyarakat. Pada perlindungan dan pengembangan itu manfaat pada pendidikan terus berkembang, pendidikan mengenal kesenian Sintren Dangdut bukan hanya monoton dan begitu saja tetapi lebih mengetahui bisa dikembangkan atau berinovasi kembali.

2) Industri

Segi pemanfaatan industri kesenian Sintren Dangdut dikemas sebagai produk baru, kreasi baru, inovasi baru pada industry budaya. Jadi perlindungan dan pengembangan sebelumnya tidaklah sia-sia karena bermanfaat bagi industry budaya. Pengembangan industry budaya juga untuk memotivasi kesenian tradisional kerakyatan yang lain, seperti kesenian 
Sintren Dangdut berkembang akan memotivasi kesenian burok atau kesenian kerakyatan yang lain yang berkembang di masyarakat.

3) Pariwisata

Segi pemanfaatan pariwisata lebih memfokuskan wisatawan yang menonton. Kesenian Sintren Dangdut dipertunjukan untuk wisatawan umum maupun wisatawan minat khusus. Kesempatan untuk tampil pada pertunjukan acara-acara besar maupun kecil. Dengan perlindungan dan pengembangan yang sudah dilakukan bermanfaat pertunjukan Sintren Dangdut tidak monoton atau tidak hanya pertunjukan kesenian tradisional kerakyatan biasa. Tetapi pertunjukan itu pengembangan menjadi kreasi baru dan inovasi baru kesenian tradisional kerakyatan yang mementingkan minat masyarakat agar selalu disukai masyarakat.

\subsection{Faktor Pendukung dan Faktor Penghambat Perubahan Bentuk Pertunjukan Kesenian Sintren Dangdut Grup Putra Kelana di Kelurahan Pasarbatang Kabupaten Brebes}

Lingkungan yang dihadapi oleh masyarakat yang terus-menerus sama akan tetapi terus berubah baik dalam kuantitas maupun kualitas. Kondisi semacam itu berpengaruh juga pada kesenian tradisional termasuk kesenian Sintren Dangdut. Perubahan sosial termasuk dalam perubahan budaya. Kesenian termasuk dalam perubahan kebudayaan, dan dalam perubahan tersebut terdapat faktor-faktor yang menunjang. Kondisi alamiah berpengaruh pada faktor pendukung dan faktor penghambat, dilihat dari kondisi ilmiah itu dan mengacu pada konsep Soekanto, faktor pendukung dan penghambat perubahan bentuk pertunjukan sebagai berikut: 
4.6.1 Faktor Pendukung Perubahan Bentuk Pertunjukan Kesenian Sintren Dangdut

Dalam tiap masyarakat tentu ada individu-individu yang sadar akan adanya berbagai kekurangan dalam kebudayaan mereka. Dari kategori individu-individu inilah muncul para pencipta dari penemuan-penemuan baru. Menemukan hal-hal yang baru merupakan daya kreatif atau usaha pengembangan perubahan bentuk pertunjukan. Berdasarkan temuan data di lapangan dapat dikemukakan bahwa inilah faktor-faktor pendukung perubahan bentuk kesenian Sintren Dangdut:

Pertama, sistem lapisan masyarakat yang terbuka. Masyarakat yang sudah bosan atau jenuh dengan pertunjukan Sintren yang begitu-begitu saja. Kemudian grup Putra Kelana mendapat ide kreatif dengan menggabungkan atau memodifikasi kesenian Sintren dengan musik Dangdut. Ide itu berasal dari sistem masyarakat di lingkungan sekitar yang terbuka, jadi minat masyarakat menginginkan musik dangdut di dalam pertunjukan itu (wawancara Bapak Dalang 16 April 2016).

Kedua, kontak dengan kebudayaan lain. Zaman sekarang ini banyak budaya-budaya barat masuk ke Indonesia. Dengan budaya itu para seniman grup Putra Kelana mengembangkan urutan pertunjukan dengan diadakannya selingan dangdut yang menyanyikan biduan yang tidak kalah dengan artis barat. Kemudian memodifikasi musik iringan kesenian Sintren Dangdut dengan menggunakan alat musik modern bercampur dengan alat musik tradisi (wawancara Mangesthi 20 April 2016). 
Ketiga, sistem pendidikan yang maju menjadi rendahnya minat masyarakat dengan kesenian tradisional. Jadi para seniman mencoba merubah agar masyarakat berpendidikanpun bisa juga melihat pengembangan dari kesenian Sintren Dangdut, dan kesenian itu sudah tidak lagi kuno setelah di kembangkan (wawancara Bapak Dalang 20 April 2016).

\subsubsection{Faktor Penghambat Perubahan Bentuk Pertunjukan Kesenian Sintren Dangdut}

Kesenian selalu mengalami perkembangan dari waktu ke waktu yang akan mengakibatkan suatu perubahan. tetapi perubahan itu sendiri bisa jadi terhambat karena beberapa faktor. Berdasarkan temuan yang ada di lapangan, inilah faktor yang menghambat perubahan bentuk pertunjukan kesenian Sintren Dangdut:

Pertama, perkembangan ilmu pengetahuan yang lambat. Karena kebanyakan dari pelaku kesenian Sintren Dangdut tamatan SD, mereka kurang tahu perkembangan ilmu pengetahuan. Jika ilmu pengetahuan mereka lebih maka kesenian Sintren Dangdut ini akan lebih banyak pengembangan dibandingkan sekarang ini. Masih belum banyak yang mau mewarisi kesenian Sintren Dangdut tersebut (wawancara Bapak Amad 20 April 2016).

Kedua, sikap masyarakat yang tradisionalistis. Terbukti bahwa masih mempertahankan sistem dahulu yang masih melekat di masyarakat. Mitos-mitos yang beredar pada masyarakat masih banyak dipercaya masyarakat itu sendiri. Jadi terhambatlah perubahan bentuk pertunjukan kesenian Sintren Dangdut (wawancara Bapak Dalang 20 April 2016). 
Ketiga, kebiasaan dan prasangka terhadap hal-hal yang baru diketahui. Kebiasaan masyarakat Kelurahan Pasarbatang yang mentradisi masih melekat. Kebiasaan menggunakan pola lama, baik itu untuk pola pentas, pola iringan, pola pertunjukan kesenian Sintren Dangdut. Jadi dengan tidak mau mengubah pola lama dengan yang baru, hal itulah yang menjadi penghambat perubahan bentuk kesenian Sintren Dangdut (wawancara Bapak Dalang 20 April 2016). 


\section{BAB 5}

\section{PENUTUP}

\subsection{Simpulan}

Berdasarkan hasil penelitian dan pembahasan mengenai Bentuk Pertunjukan Kesenian Sintren Dangdut Sebagai Upaya Pelestarian Seni Tradisi Pada Grup Putra Kelana Di Kelurahan Pasarbatang Kabupaten Brebes, yaitu adanya perbedaan pada pertunjukan kesenian Sintren Dangdut dengan kesenian Sintren yang terdahulu. Pertunjukan kesenian Sintren pada Grup Putra Kelana ini telah di modifikasi dengan musik dangdut. Musik dangdut dalam pertunjukan kesenian Sintren bermula dari minat masyarakat yang sudah bosan dengan kesenian tradisional yang monoton dan tidak ada daya tarik untuk menonton. Pada Grup Putra Kelana ini menggabungkan kesenian Sintren dengan dangdut sehingga menjadikan pertunjukan Sintren Dangdut.

Bentuk pertunjukan peneliti mengambil konsep Soedarsono dengan Kusmayati yaitu pada bentuk pertunjukan mempunyai aspek-aspek seperti lakon, gerak, pelaku, iringan, rias, busana, tata pentas, property, penonton, dan urutan pertunjukan. Lakon dalam kesenian Sintren Dangdut yaitu penari Sintren. Gerak yang ditarikan penari Sintren Dangdut bukan atas kemauannya sendiri, melainkan Sintren dirasuki roh bidadari (intrance), sehingga gerakan yang dilakukan hanya berulang-ulang. Pelaku pada pertunjukan Sintren Dangdut meliputi pemeran Sintren Dangdut, pawang, bodhor, sinden, penyanyi dangdut, kemladang, 
pemusik, pembawa acara. Iringan pada pertunjukan kesenian Sintren Dangdut sudah menggunakan iringan modern dengan adanya gitar elektrik dan keyboard.

Rias pada penari Sintren Dangdut sangat sederhana dikarenakan kesenian Sintren Dangdut termasuk dalam kesenian tradisional kerakyatan. Busana yang digunakan pada kesenian Sintren Dangdut dibuat sendiri dengan bahan yang relatif murah, mudah didapat dan mendukung penampilan. Tata pentas pada pertunjukan kesenian Sintren Dangdut sudah menggunakan panggung dan berlampu kerlap-kerlip. Properti yang dipersiapkan untuk dipakai adalah kurungan, kain penutup kurungan, layah atau anglo, dupa atau kemenyan, arang, sesaji, doa. Penonton pertunjukan Sintren Dangdut adalah orang yang melihat kesenian Sintren Dangdut yang terdiri dari seluruh warga Kelurahan Pasarbatang dan warga Kelurahan lain yang datang untuk melihat. Urutan pertujukan pada kesenian Sintren Dangdut terdiri dari bagian awal, bagian pertunjukan dan akhir pertunjukan.

Upaya pelestarian seni tradisi dalam bentuk pertunjukan kesenian Sintren Dangdut ada tiga konsep Sedyawati yaitu perlindungan, pengembangan, dan pemanfaatan. Banyak upaya perlindungan dalam kesenian Sintren Dangdut ini, dan juga banyak pengembangan yang hadir pada bentuk pertunjukan kesenian Sintren Dangdut. Namun dalam perlindungan dan pengembangannya terdapat pula pemanfaatan yang hadir pada bentuk pertunjukan kesenian Sintren Dangdut seperti menarik perhatian masyarakat agar kesenian Sintren Dangdut tidak punah. Perlindungan kesenian Sintren Dangdut meliputi perlindungan hukum, dokumentasi dan fasilitas. Bentuk pengembangan kesenian Sintren Dangdut 
meliputi diskusi, fasilitas, dan pengembangan kreasi baru inovatif. Bentuk Pemanfaatan dalam bentuk pertunjukan kesenian Sintren Dangdut yaitu pendidikan, industri, dan pariwisata.

Perubahan kebudayaan terdapat faktor-faktor yang menunjang termasuk faktor pendukung dan penghambat. Dalam faktor pendukung perubahan bentuk kesenian Sintren Dangdut antara lain yaitu sistem lapisan masyarakat yang terbuka, kontak dengan kebudayaan lain, dan sistem pendidikan yang manju menjadi rendahnya minat masyarakat dengan kesenian tradisional. jadi para seniman mencoba merubah agar masyarakat berpendidikan bisa juga melihat pengembangan dari Sintren Dangdut, dan kesenian itu sudah tidak lagi kuno setelah dikembangkan.

Selain faktor pendukung perubahan bentuk terdapat juga faktor penghambat perubahan bentuk kesenian Sintren Dangdut antara lain yaitu perkembangan ilmu pengetahuan yang lambat, sikap masyarakat yang tradisionalistis, dan kebiasaan prasangka terhadap hal-hal yang baru diketahui. Jadi dengan adanya perubahan bentuk kesenian tradisional diharapkan bisa mengembangkan dan memajukan kesenian tradisional terutama kesenian Sintren Dangdut yang ada di kabupaten Brebes. 


\subsection{Saran}

Dari hasil penelitian mengenai Bentuk Pertunjukan Kesenian Sintren Dangdut Sebagai Upaya Pelestarian Seni Tradisi Pada Grup Putra Kelana Di Kelurahan Pasarbatang Kabupaten Brebes, maka dapat diberikan saran-saran sebagai berikut:

(1) Kelompok kesenian tradisional Sintren Dangdut di Kabupaten Brebes diharapkan dapat menciptakan bentuk-bentuk kreasi yang inovatif. Hal itu demi kelestarian kesenian tradisional sebagai kekayaan daerah serta kekayaan budaya dan kesenian bangsa yang sudah seharusnya dilestarikan dan dikembangkan.

(2) Perlunya tempat (sanggar) kesenian supaya tetap terjaga kesenian-kesenian tradisional dan bisa bergenerasi.

(3) Perlunya pertunjukan rutin dalam wilayah kabupaten Brebes agar masyarakat dan generasi muda mengetahui adanya kesenian tradisional dan tidak buta akan adanya kesenian tradisional serta salah satu pelestaraian budaya.

(4) Perlunya diadakan atau diterbitkan buku-buku tentang Sintren Dangdut karena sangat langka, dan agar lebih mudah mempelajari dan mengetahui sejarah kesenian Sintren Dangdut.

Perlunya penelitian lebih lanjut untuk kesenian-kesenian tradisional di kabupaten Brebes. 


\section{REFERENCES}

Arifin, Zaenal. 2015. "Bentuk Pertunjukan dan Fungsi Kesenian Musik Rebana Grup Asy-Syabab di Desa Trahan Kecamatan Sluke Kabupaten Rembang”. Skripsi. Semarang: UNNES.

Arikunto, Suharsimi. 1996. Prosedur Penelitian Suatu Pendekatan Praktis. Jakarta: Rineka Cipta.

Cahyono, Agus. 2006. "Seni pertunjukan Arak-Arakan dalam Upacara Tradisional Dugdheran di Kota Semarang”. Harmonia. Volume VII. Nomor 3. Hlm. 239-248. Semarang: Universitas Negeri Semarang.

Dewi, Krisna Mustikasari. 2013. "Fungsi Musik Iringan Dalam Kesenian Sintren Di Desa Pagejugan Kabupaten Brebes”. Tesis. Semarang: UNNES.

Djelatik, A. A. M. 1990. Estetika Sebuah Pengantar. Bandung: Masyarakat Seni Pertunjukan Indonesia.

Gustini, Heni dan Muhammad Alfan. 2012. Studi Budaya di Indonesia. Bandung: CV Pustaka Setia.

Hadi, Sumandiyo. 1996. Aspek-Aspek Koreografi Kelompok. Yogyakarta: Manthili.

Harjono, Slamet. 2002. "Dangdut dan Eksploitasi Seks Perempuan”, dalam Harmonia Jurnal Pengetahuan dan Pemikiran Seni Volume 3 Nomer 2/MeiAgustus. Semarang.

Humardani, SD. 2003. Beberapa Pikiran Dasar Tentang Seni Tradisi. Surakarta : ASKI.

Indrawan, Bagus. 2013. "Bentuk dan Fungsi Pertunjukan Musik Pengiring Seni Sintren Lais di Desa Balapulang Kulon Kabupaten Tegal". Skripsi. Semarang: UNNES.

Jazuli, M. 1994. Telaah Teoritis Seni Tari. Semarang: IKIP Semarang Press. 2008. Pendidikan Seni Budaya Suplemen Pembelajaran Seni Tari. Semarang: UNNES Press. 2011. Sosiologi Seni. Surakarta : Universitas Negeri Semarang.

Kamus Besar Bahasa Indonesia. 2005. Jakarta: Balai Pustaka. 
Kayam, Umar. 1981. Seni, Tradisi, Masyarakat. Jakarta: Sinar Harapan. 2003. Seni, Tradisi, Masyarakat. Jakarta: Sinar Harapan.

Koentjaraningrat. 2009. Pengantar Ilmu Antropologi. Jakarta: Rineka Cipta.

Kusmayati, Hermien. 2000. “Arak-Arakan” Seni Pertunjukan dalam Upacara Tradisional di Madura. Yogyakarta: Tarawang Press.

Kusumastuti, Eny. 2006. Laesan sebuah Fenomena Kesenian Pesisir : Kajian Interaksi Simbolik antara Pemain dan Penonton. Harmonia: Journal of Arts Research and Education,7(3), 199.

Ambarwangi, S., \& Suharto, S. (2014). REOG AS MEANS OF STUDENTS' APPRECIATION AND CREATION IN ARTS AND CULTURE BASED ON THE LOCAL WISDOM. Harmonia: Journal Of Arts Research And Education, 14(1), 37-45. doi:http://dx.doi.org/10.15294/harmonia.v14i1.2789

Ambarwangi, S., \& Suharto, S. (2013). PENDIDIKAN MULTIKULTURAL DI SEKOLAH MELALUI PENDIDIKAN SENI TRADISI. Harmonia: Journal Of Arts Research And Education, 13(1). doi:http://dx.doi.org/10.15294/harmonia.v13i1.2535

Subandi, -. (2011). Lakon Anoman Duta Garap Padat: Sebuah Penelitian Singkat (The Condensed Creativity of Anoman Duta : A Short Study). Harmonia: Journal Of Arts Research And Education, 6(3). doi:http://dx.doi.org/10.15294/harmonia.v6i3.813

Suharto, S., \& Aesijah, S. (2014). THE LESUNG MUSIC IN THE VILLAGE OF LEDOK BLORA REGENCY. Harmonia: Journal Of Arts Research And Education, $\quad 14(1)$, doi:http://dx.doi.org/10.15294/harmonia.v14i1.2851

65-71.

Putra, B. (2013). PENGEMBANGAN MODEL KONSERVASI KESENIAN LOKAL SEBAGAI KEMASAN SENI WISATA DI KABUPATEN SEMARANG. Harmonia: Journal Of Arts Research And Education, 12(2). doi:http://dx.doi.org/10.15294/harmonia.v12i2.2525

Irianto, A. (2016). The Development of Jathilan Performance as an Adaptive Strategy Used by Javanese Farmers. Harmonia: Journal Of Arts Research And Education, 16(1), 38-48. doi:http://dx.doi.org/10.15294/harmonia.v16i1.5213

Hapsari, L. (2014). FUNGSI TOPENG IRENG DI KURAHAN KABUPATEN MAGELANG. Harmonia: Journal Of Arts Research And Education, 13(2). doi:http://dx.doi.org/10.15294/harmonia.v13i2.2780 
Budiarti, M. (2011). MENGUBAHÂ CITRA LENGGER MENJADIÂA MEDIA EKSPRESIÂ ESTETIS (To Change the Image of Lengger Into Esthetic $\hat{A}$ Medium of Expression). Harmonia: Journal Of Arts Research And Education, 4(2). doi:http://dx.doi.org/10.15294/harmonia.v4i2.708

Darmasti. "TARI SESAJI PANGENTAS BILAHI SUDRA TINGAL." Harmonia: Journal of Arts Research and Education [Online], 12.2 (2012): n. pag. Web. 24 Sep. 2017

Tarwiyah, T. (2011). PELESTARIAN BUDAYA BETAWI PERMAINAN ANAK CICI PUTRI DAN ULABANG/ WAK WAK GUNG : KAJIAN KANDUNGAN KECERDASAN JAMAK. Harmonia: Journal Of Arts Research And Education, 10(1). doi:http://dx.doi.org/10.15294/harmonia.v10i1.51

Tarwiyah, T. (2011). ANALISIS NILAI-NILAI PENDIDIKAN DALAM LAGULAGU DAERAH BETAWI (An Analysis of Educational Values in Songs of the BetawiArea). Harmonia: Journal Of Arts Research And Education, 5(1). doi:http://dx.doi.org/10.15294/harmonia.v5i1.831

Widodo, B. (2011). SLENDRO PELOG: SUATU KETERASINGAN DI DUNIA ANAK. Harmonia: Journal Of Arts Research And Education, 1(1). doi:http://dx.doi.org/10.15294/harmonia.v1i1.837

Widodo, W. (2011). Nuansa Laras Diatonik dalam Macapat Semarangan (Diatonic Scale Atmosphere in Semarang Style Macapat).. Harmonia: Journal Of Arts Research And Education, 7(1). doi:http://dx.doi.org/10.15294/harmonia.v7i1.751

Wiyoso, J. (2011). PENGARUH DIFUSI DALAM BIDANG MUSIK TEHADAP KARAWITAN (The Influence Diffusion of Music to Karawitan). Harmonia: Journal Of Arts Research And Education, 3(2). doi:http://dx.doi.org/10.15294/harmonia.v3i2.687

Wiyoso, J. (2017). Puppet Visual Adaptation on Playing Cards as Educational Media. Harmonia: Journal Of Arts Research And Education, 16(2), 182191. doi:http://dx.doi.org/10.15294/harmonia.v16i2.5816

Kusumastuti, E. (2011). PENDIDIKAN SENI TARI PADA ANAK USIA DINI DI TAMAN KANAK-KANAK TADIKA PURI CABANG ERLANGGA SEMARANG SEBAGAI PROSES ALIH BUDAYA. Harmonia: Journal Of Arts Research And Education, 5(1). doi:http://dx.doi.org/10.15294/harmonia.v5i1.826

Pratjichno, B. (2011). Pornografi dalam Dunia Seni Tari (Pornography in Dance World). Harmonia: Journal Of Arts Research And Education, 7(2). doi:http://dx.doi.org/10.15294/harmonia.v7i2.769

Haryono, S. (2011). DANGDUT DAN EKSPLOITASI SEKS PEREMPUAN (Dangdut and Woman Sex Exploitation). Harmonia: Journal Of Arts 
Research

And

Education,

$3(2)$.

doi:http://dx.doi.org/10.15294/harmonia.v3i2.688

Budiarti, M. (2011). MENGUBAH CITRA LENGGER MENJADI MEDIA

EKSPRESI ESTETIS (To Change the Image of Lengger Into Esthetic

Medium of Expression). Harmonia: Journal Of Arts Research And Education, 4(2). doi:http://dx.doi.org/10.15294/harmonia.v4i2.708

Hidajat, R. (2014). The Popularity of Waranggana Tayub Malang through Body Exploitation. Harmonia: Journal Of Arts Research And Education, 14(2), 72-77. doi:http://dx.doi.org/10.15294/harmonia.v14i2.3288

Lestari, Wahyu. 1993. Teknologi Rias Panggung. Hand Out: IKIP Semarang.

Maryono. 2011. Penelitian Kualitatif Seni pertunjukan. Solo: ISI Press. 2012. Analisa Tari. Solo: ISI Press.

Murgiyanto, Sal. 1983. Koreografi. Jakarta: Depdikbud.

1986. Komposisi Tari Dalam Pengetahuan Elementari dan Beberapa Masalah Tari. Jakarta: Direktorat Kesenian.

2004. Tradisi dan Inovasi: Beberapa Masalah Tari Di Indonesia. Jakarta: Wedatama Widya Sastra.

Rahyono, F.X. 2015. Kearifan Budaya Dalam Kata. Jakarta: Wedatama Widya Sastra.

Rianawati. 2014. Seni Tari: Untuk SMP dan MTs. Solo: PT Tiga Serangkai Pustaka Mandiri.

Rokhana, Sri dan Wahyudiarto. 2014. Pengantar Koreografi. Surakarta: ISI Press.

Rohidi, Rohendi Tjetjep. 2011. Metodologi Penelitian Seni. Semarang: Cipta Prima Nusantara.

Sedyawati, Edi. 1981. Pertumbuhan Seni Pertunjukan. Jakarta: Sinar Harapan.

. 2006. Budaya Indonesia Kajian Arkeologi, Seni, dan Sejarah. Jakarta: PT Raja Grafindo Persada.

Sasatra.

Sedyawati, Edi, dkk. 1986. Pengetahuan Elementer Tari dan Beberapa Masalah Tari. Jakarta: Direktorat Kesenian Proyek Pengembangan Kesenian Jakarta Departemen Pendidikan dan Kebudayaan.

Soedarsono, R.M. 1976. Tari-tarian Rakyat di Daerah Istimewa Yogyakarta. Yogyakarta: Gajah Mada University Press. 
. 1978. Tari- Tarian Indonesia I. Jakarta: Balai Pustaka.

2001. Metodologi Penelitian Seni Pertunjukan dan Seni Rupa. Bandung: Masyarakat Seni Pertunjukan Indonesia.

. 2002. Seni Pertunjukan Indonesia di Era Globalisasi. Yogyakarta: Gajah Mada University Press.

2003. Seni Pertunjukan Dari Perspektif Politik, Sosial,dan Ekonomi. Yogyakarta: Gajah Mada University Press.

Soekanto, Soerjono. 1990. Sosiologi Suatu Pengantar. Jakarta: Rajawali Press.

Sugiyono. 2011. Metode penelitian Kuantitatif Kualitatif dan R\&D. Bandung: Alfabeta.

2012. Metode Penelitian Pendidikan Pendekatan Kuantitatif, Kualitatif, dan R\&D. Bandung: Alfabeta.

Suharto, M. 1995. Kamus Musik Indonesia. Jakarta : PT. Gramedia.

Sinaga, Syahrul. 2006. "Fungsi dan Ciri khas Kesenian Rebana di Pantura Jawa Tengah.” Harmonia. Volume VII. Nomor 3. Hlm. 199. Semarang:

Universitas Negeri Semarang.

Sutiyono. 2009. Puspawarna Seni Tradisi dalam Perubahan Sosial-Budaya. Yogyakarta : Kanwa Publisher.

Tim MKU PLH. 2014. Pendidikan Lingkungan Hidup. Semarang: Universitas Negeri Semarang.

Wahyuningsih, Beti. 2012. "Manajemen Kesenian Sintren Dangdut pada Grup Musik Eka Nada di Desa Pagejugan Brebes". Skripsi. Semarang: UNNES

http://imungblog.blogspot.co.id/2013/03/melestarikan-dan-menjagakebudayaan.html (diakses pada 7 Januari 2016)

http://pusbangkol.perpusnas.go.id/resensi-1.html (diakses pada 3 Maret 2016)

http://id.m.wikipedia.org/wiki/Sintren (diakses pada 4 Maret 2016) 


\section{GLOSARIUM}

B

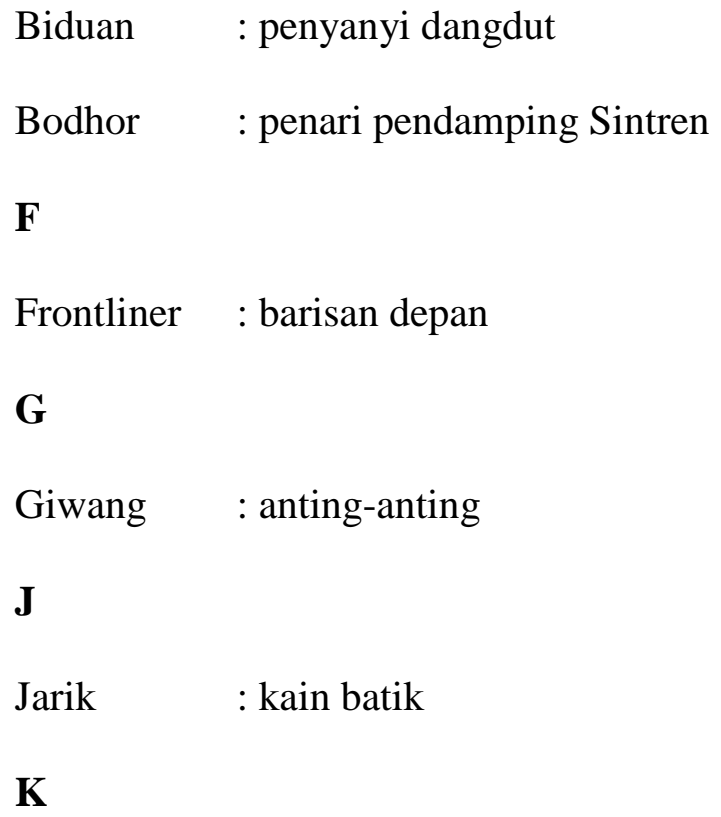




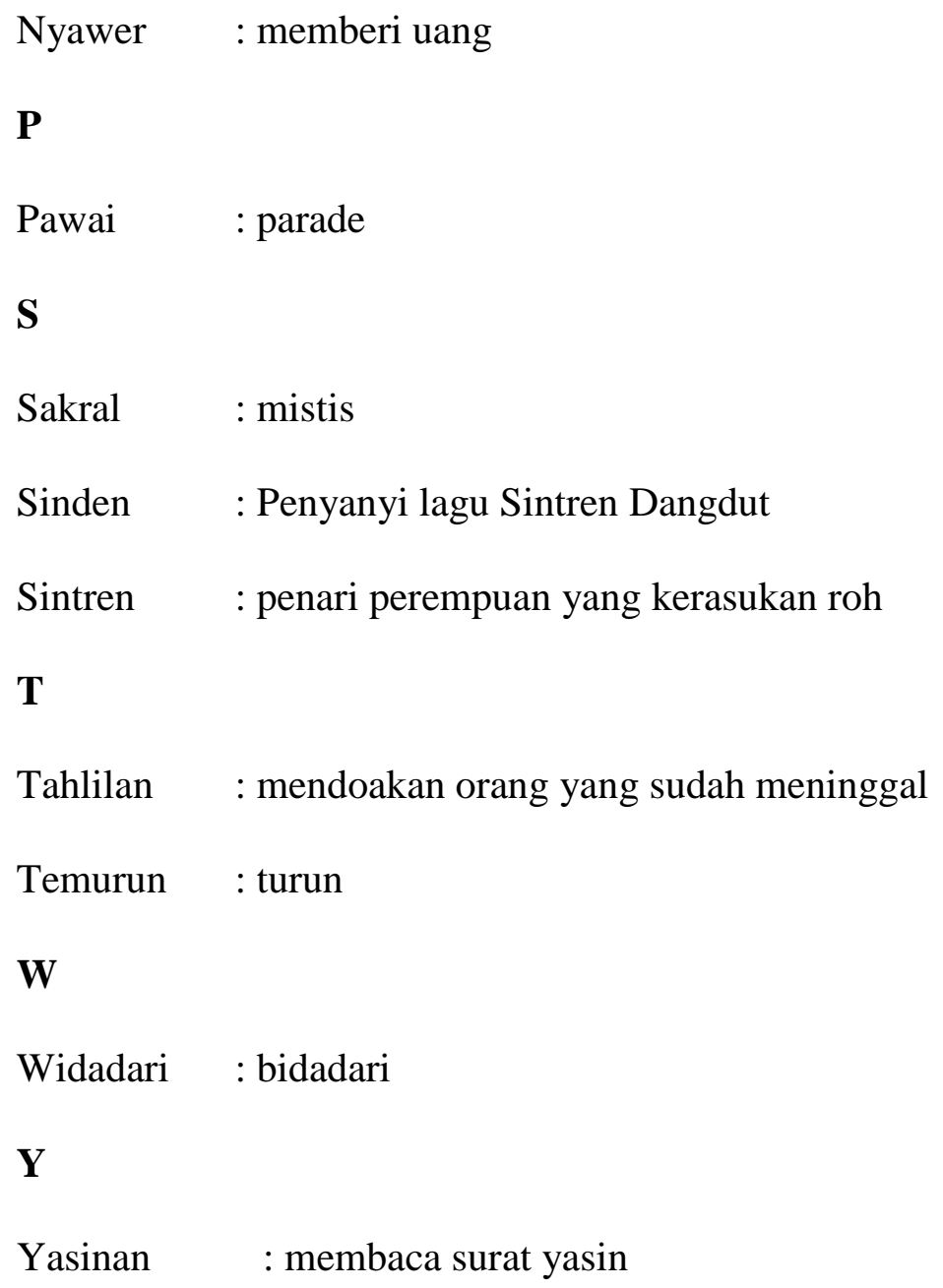


Lampiran 1

\section{Sก) \\ UNNES \\ KEPUTUSAN \\ DEKAN FAKULTAS BAHASA DAN SEN \\ UNIVERSITAS NEGERI SEMARANG \\ Nomor: $79 / F B S / 2016$ \\ PENETAPAN DOSEN PEMBIMBING SKRIPS \\ GASAL/GENAP \\ TAHUN AKADEMIK 2015/2016}

Menimbang : Bahwa untuk memperlancar mahasiswa Jurusan/Prodi Seni Drama, Tari, dan Musik/Pend. Sendratasik Fakultas Bahasa dan Seni membuat Skripsi/Tugas Akhir, maka perlu menetapkan Dosen-dosen Jurusan/Prodi Seni Drama, Tari, dan Musik/Pend. Sendratasik Fakultas Bahasa dan Seni UNNES untuk menjadi pembimbing.

Mengingat : 1. Undang-undang No.20 Tahun 2003 tentang Sistem Pendidikan Nasional (Tambahan Lembaran Negara RI No.4301, penjelasan atas Lembaran Negara RI Tahun 2003 , Nomor 78)

2. Peraturan Rektor No. 21 Tahun 2011 tentang Sistem Informasi Skripsi UNNES

3. SK. Rektor UNNES No. 164/O/2004 tentang Pedoman penyusunan Skripsi/Tugas Akhir Mahasiswa Strata Satu (S1) UNNES

4. SK Rektor UNNES No.162/O/2004 tentang penyelenggaraan Pendidikan UNNES;

Menimbang : Usulan Ketua Jurusan/Prodi Seni Drama, Tari, dan Musik/Pend. Sendratasik Tanggal 7 Januari 2016

\section{MEMUTUSKAN}

Menetapkan PERTAMA

Menunjuk dan menugaskan kepada:

1. Nama : Drs. Bintang Hanggoro Putra, M.Hum. NIP : 196002081987021001

Pangkat/Golongan : IVIA

Jabatan Akademik : Lektor Kepala

Sebagai Pembimbing I

2. Nama : Joko Wiyoso, S.Kar. M.Hum

NIP : 196210041988031002

Pangkat/Golongan : IV/C

Jabatan Akademik : Lektor Kepala

Sebagai Pembimbing II

Untuk membimbing mahasiswa penyusun skripsi/Tugas Akhir :

Nama : AMALIA MEGA HARDIYANTI

NIM : 2501412015

Jurusan/Prodi : : Seni Drama, Tari, dan Musik/Pend. Sendratasik

Topik : Bentuk Pertunjukan Kesenian Sintren Dangdut Sebagai Upaya Pelestarian Seni Tradisi Pada Grup Putra Kelana Di Kelurahan Pasarbatang Kabupaten Brebes

KEDUA : Keputusan ini mulai berlaku sejak tanggal ditetapkan.

Tembusan

1. Pembantu Dekan Bidang Akademik

2. Ketua Jurusan

3. Petinggal

DITETAPKAN DI : SEMARANG

PADA TANGGAL : 7 Januari 2016 DEKAN

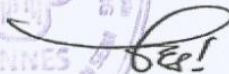

2501412015

Prof. Dr. Agus Nuryatin, M.Hum. NIP 196008031989011001 


\section{Lampiran 2}

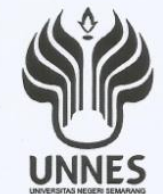

\section{KEMENTERIAN RISET, TEKNOLOGI, DAN PENDIDIKAN TINGGI UNIVERSITAS NEGERI SEMARANG FAKULTAS BAHASA DAN SENI \\ Gedung B, Kampus Sekaran, Gunungpati, Semarang 50229 \\ Telepon +62248508010 , Faksimile +62248508010}

Nomor : 1545/UN37.1.2/LT/2016

Lamp. : -

Hal. : Permohonan Izin Penelitian

Yth. Pimpinan Grup Putra Kelana

di tempat

Dengan hormat kami beritahukan bahwa dalam rangka penyusunan skripsi mahasiswa kami,

nama

nim

: Amalia Mega Hardiyanti

jurusan : 2501412015

: Seni Drama Tari dan Musik

program studi : Pendidikan Seni Tari

jenjang : :S1

tahun akademik $\quad: 2015 / 2016$

judul

: Bentuk Pertunjukan Kesenian Sintren Dangdut Sebagai Upaya Pelestarian Seni Tradisi Pada Grup Putra Kelana Di Kelurahan Pasarbatang Kabupaten Brebes.

akan mengadakan penelitian di Grup Putra Kelana Kelurahan Pasarbatang Kabupaten Brebes, waktu pelaksanaan April 2016 s.d. selesai. Untuk itu kami mohon Saudara berkenan memberikan izin kepada mahasiswa di atas untuk keperluan tersebut.

Atas perhatian dan kerja sama Saudara, kami sampaikan terima kasih.

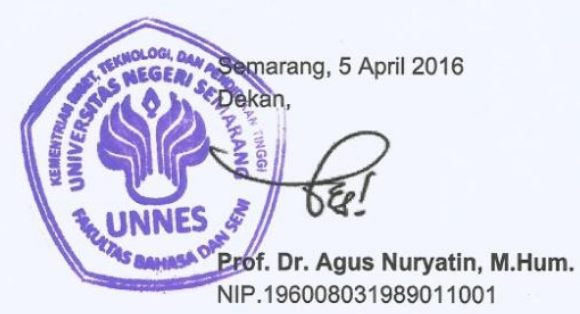

Tembusan:

1. Pembantu Dekan Bidang Akademik

2. Ketua Jurusan

3. Pertinggal

FM-05-AKD-24 
Lampiran 3

\section{Anggota Grup Kesenian Sintren "PUTRA KELANA"}

\section{Kelurahan Pasarbatang Kabupaten Brebes}

9. Pimpinan : Bpk. Dalang Wertadiharjo

10. Pelindung : Bpk. Sugiarto, Polres Brebes

11. Sintren : Mala

12. Pawang : Ibu Musdah

13. Bodhor : Ipung

14. Sinden : Ibu Tarminah

15. Penyanyi Dangdut : Firli

16. Pemusik :

g. Melodi : Amad

h. Suling : Rahman

i. Kecrek : Ambari

j. Tutukan : Duha

k. Blampak : Rawad

1. Gong : Dalang 
Lampiran 4

\section{INSTRUMEN PENELITIAN}

Judul: Bentuk Pertunjukan Kesenian Sintren Dangdut Sebagai Upaya Pelestarian Seni Tradisi Pada Grup Putra Kelana di Kelurahan Pasarbatang Kabupaten Brebes.

\section{A. Pedoman Observasi}

\section{Bagaimana gambaran umum lokasi penelitian:}

1. Letak lokasi penelitian

2. Kondisi geografis atau lingkungan alam

\section{Bagaimana kondisi penduduk:}

1. Berdasarkan jenis kelamin

2. Berdasarkan pendidikan

3. Berdasarkan mata pencaharian

4. Berdasarkan agama

3. Bagaimana bentuk pertunjukan kesenian Sintren Dangdut Grup Putra Kencana

1. Asal-usul kesenian Sintren Dangdut

2. Urutan pertunjukan kesenian Sintren Dangdut Grup Putra Kelana

3. Ragam gerak yang ditarikan dalam pertunjukan kesenian Sintren Dangdut Grup Putra Kelana

4. Rias dan busana yang digunakan dalam pertunjukan kesenian Sintren Dangdut Grup Putra Kelana 
5. Tembang dan iringan yang digunakan dalam pertunjukan kesenian Sintren Dangdut Grup Putra Kelana

6. Ciri khas pertunjukan kesenian Sintren Dangdut Grup Putra Kelana

7. Perlengkapan yang mendukung pertunjukan kesenian Sintren Dangdut Grup Putra Kelana

4. Apa saja upaya pelestarian seni tradisi dalam bentuk kesenian Sintren

\section{Dangdut}

1. Pelestarian seni tradisi dengan pertahanan dalam bentuk pertunjukan kesenian Sintren Dangdut

2. Pelestarian seni tradisi dengan pengembangan dalam bentuk pertunjukan kesenian Sintren Dangdut

3. Faktor-faktor pendukung dan penghambat bentuk pertunjukan kesenian Sintren Dangdut sebagai upaya pelestarian seni tradisi

\section{B. Pedoman Wawancara}

\section{Pimpinan Grup Sintren Dangdut Putra Kelana, meliputi:}

1. Bagaimana sejarah keberadaan Sintren Dangdut grup Putra Kelana di Kelurahan Pasarbatang?

2. Sejak kapan kesenian Sintren Dangdut pada grup Putra Kelana muncul?

3. Apakah lahirnya kesenian Sintren pertama kali sudah dipadukan dengan dangdut atau baru beberapa tahun saja?

4. Apa fungsi dari kesenian Sintren Dangdut?

5. Apa keunikan dari pertunjukan kesenian Sintren Dangdut grup Putra Kelana? 
6. Apa saja upaya pelestarian seni tradisi pada grup Putra Kelana?

7. Bagaimana pengaruh lingkungan masyarakat sekitar jika menampilkan Sintren Dangdut?

8. Alasan apa yang menyebabkan Sintren Dangdut tetap ada pada grup Putra Kelana?

\section{Tokoh masyarakat, meliputi:}

1. Bagaimana tanggapan anda mengenai pertunjukan Sintren Dangdut?

2. Bagaimana kesan anda mengenai pertunjukan Sintren Dangdut?

3. Apa saja upaya pelestarian seni tradisi dalam bentuk pertunjukan kesenian Sintren Dangdut grup Putra Kelana?

\section{Pawang, meliputi:}

1. Persiapan apa saja yang dilakukan sebelum pertunjukan?

2. Adakah ritual-ritual khusus sebelum pertunjukan Sintren Dangdut?

3. Apa saja upaya pelestarian seni tradisi dalam bentuk pertunjukan kesenian Sintren Dangdut grup Putra Kelana?

\section{Penari Sintren, meliputi:}

1. Sejak kapan menjadi penari Sintren Dangdut?

2. Alasan apa yang menyebabkan menjadi penari Sintren Dangdut?

3. Persiapan apa saja yang dilakukan sebelum pertunjukan?

4. Apa yang dirasakan sebelum pentas, pada saat pentas, dan setelah pentas?

5. Ragam gerak apa saja yang digunakan dalam pertunjukan Sintren Dangdut? 
6. Apa ada ritual khusus saat akan menjadi penari Sintren Dangdut?

7. Apa saja upaya pelestarian seni tradisi dalam bentuk pertunjukan kesenian Sintren Dangdut grup Putra kelana melalui gerakannya?

\section{Sinden, meliputi:}

1. Ritual apa saja yang dilakukan sebelum pertunjukan Sintren Dangdut?

2. Lagu apa saja yang dinyanyikan pada saat pertunjukan Sintren Dangdut?

3. Apa saja upaya pelestarian seni tradisi dalam bentuk pertunjukan kesenian Sintren Dangdut grup Putra Kelana melalui lagu-lagunya?

\section{Penyanyi Dangdut, meliputi:}

1. Sejak kapan bergabung dalam kesenian Sintren grup Putra Kelana?

2. Apa ada ritual sendiri yang dilakukan sebelum pertunjukan Sintren Dangdut?

3. Lagu apa saja yang dinyanyikan pada saat pertunjukan Sintren Dangdut?

4. Busana seperti apa yang dipakai pada saat pertunjukan Sintren Dangdut?

5. Apa saja upaya pelestarian seni tradisi dalam bentuk pertunjukan kesenian Sintren Dangdut grup Putra Kelana?

\section{Bodor (Penari Pendamping), meliputi:}

1. Sejak kapan ikut bergabung dengan grup Sintren Dangdut grup Putra kelana?

2. Persiapan apa saja yang dilakukan sebelum pertunjukan? 
3. Ragam gerak apa saja yang digunakan tokoh Bodor dalam pertunjukan Sintren Dangdut?

4. Bagaimana tata rias dan busana yang dikenakan oleh Bodor?

5. Apa saja upaya pelestarian seni tradisi dalam bentuk pertunjukan kesenian Sintren Dangdut grup Putra Kelana?

\section{Pemusik, meliputi:}

1. Jenis musik apa yang dimainkan?

2. Alat musik apa saja yang digunakan untuk mengiringi pertunjukan Sintren Dangdut?

3. Berapa jumlah pemain musik pengiring Sintren Dangdut?

4. Apa saja upaya pelestarian seni tradisi dalam bentuk pertunjukan kesenian Sintren Dangdut grup Putra Kelana melalui musik yang dimainkan?

\section{Pedoman Dokumentasi}

\section{Dokumen foto pertunjukan}

1. Pertunjukan Sintren Dangdut

2. Tata rias wajah dan busana penari Sintren Dangdut

3. Alat musik pendukung

\section{Video}

1. Pertunjukan Sintren Dangdut 
Lampiran 5

\section{PETA INDEKS KECAMATAN BREBES}

\section{KABUPATEN BREBES}

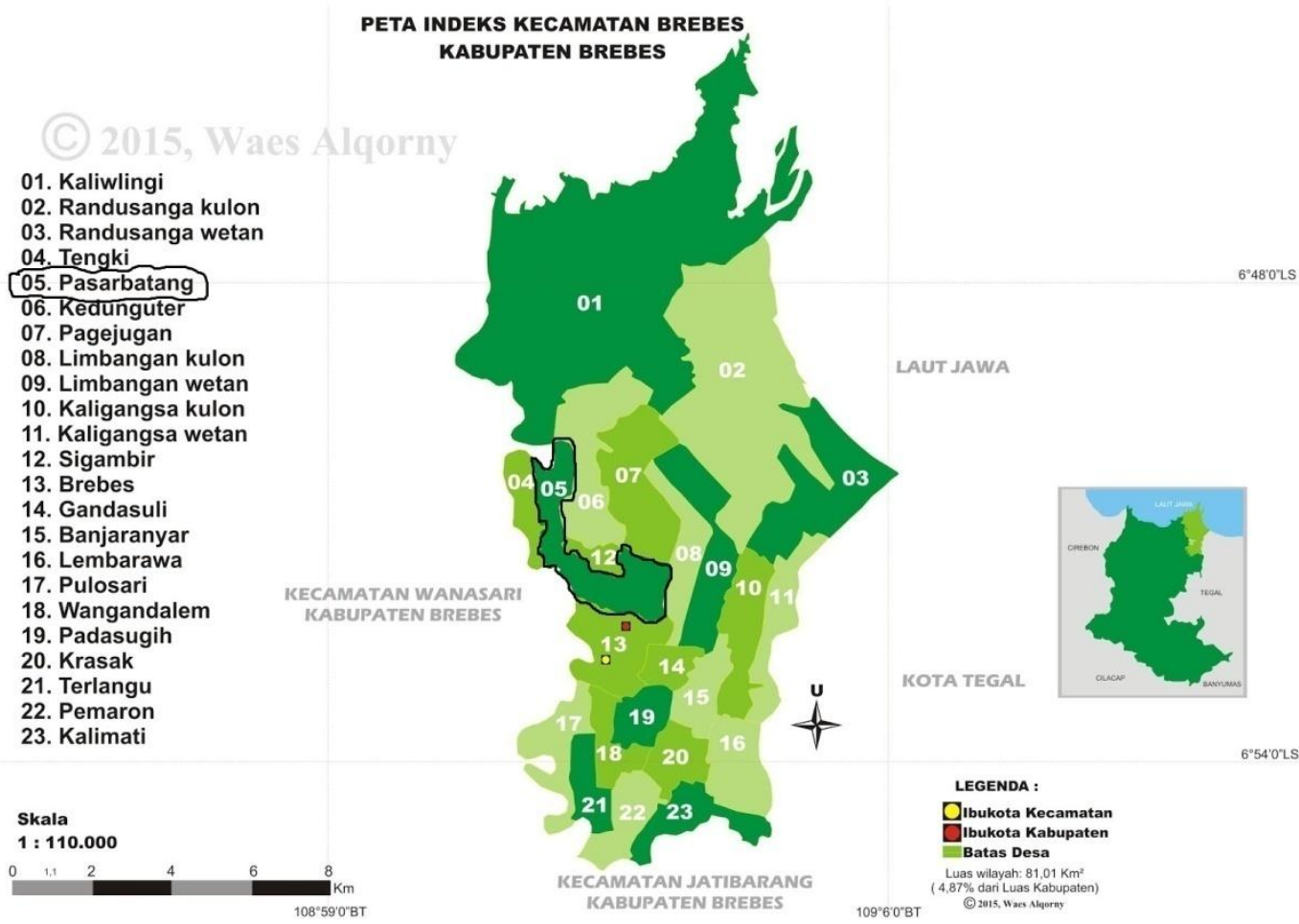

Foto 23

Peta Indeks Kecamatan Brebes

(dokumentasi: google.com) 
Lampiran 6

\section{Profil Informan}

1. Nama : Dalang Wertadiharjo

Umur $\quad: 58$

Pekerjaan : Pimpinan Grup Kesenian Sintren Dangdut "Putra Kelana"

2. Nama : Mangesthi Lestari D. S

Umur : 23 tahun

Pekerjaan : Mahasiswa (tokoh masyarakat)

3. Nama : Musdah

Umur $\quad: 56$

Pekerjaan : Pawang grup kesenian Sintren Dangdut "Putra Kelana"

4. Nama : Mala

Umur : 13 tahun

Pekerjaan : Siswa SD

5. Nama : Tarminah

Umur : 42 tahun

Pekerjaan : Sinden grup kesenian Sintren Dangdut "Putra Kelana"

6. Nama : Firli

Umur : $\quad 35$ tahun

Pekerjaan : Biduan grup kesenian Sintren Dangdut "Putra Kelana"

7. Nama : Ipung

Umur : 13 tahun

Pekerjaan : Siswa SD 
8. Nama : Amad

Umur : 43 tahun

Pekerjaan : Pemusik grup kesenian Sintren Dangdut "Putra Kelana" 
Lampiran 7

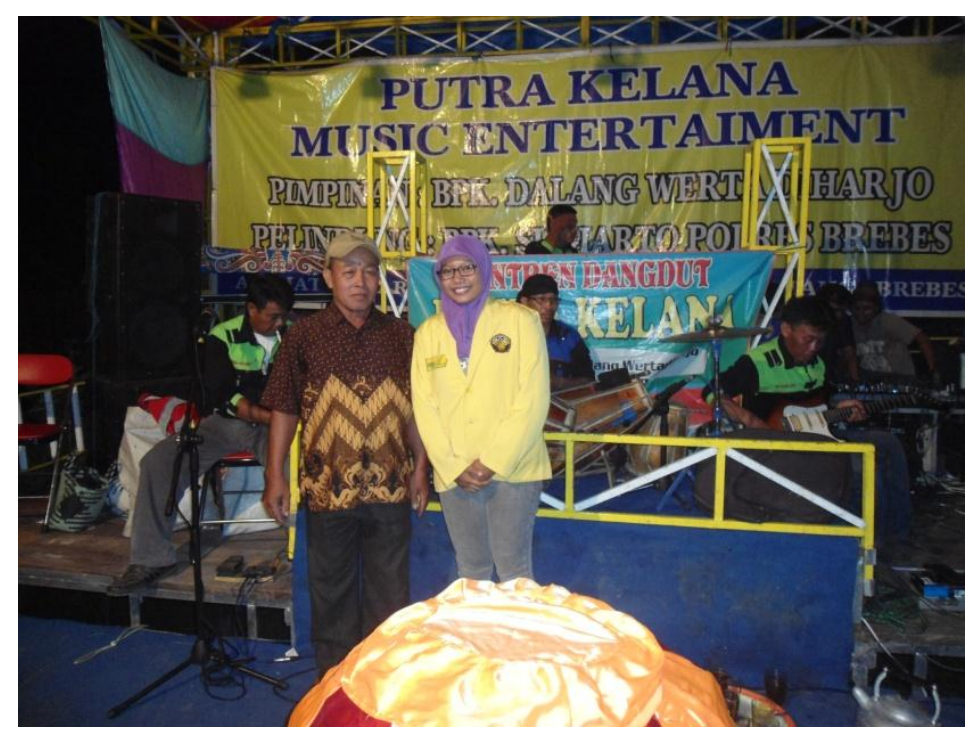

Foto 24

Malam Pertunjukan Sintren Dangdut (dokumentasi: Rani, Brebes Maret 2016)

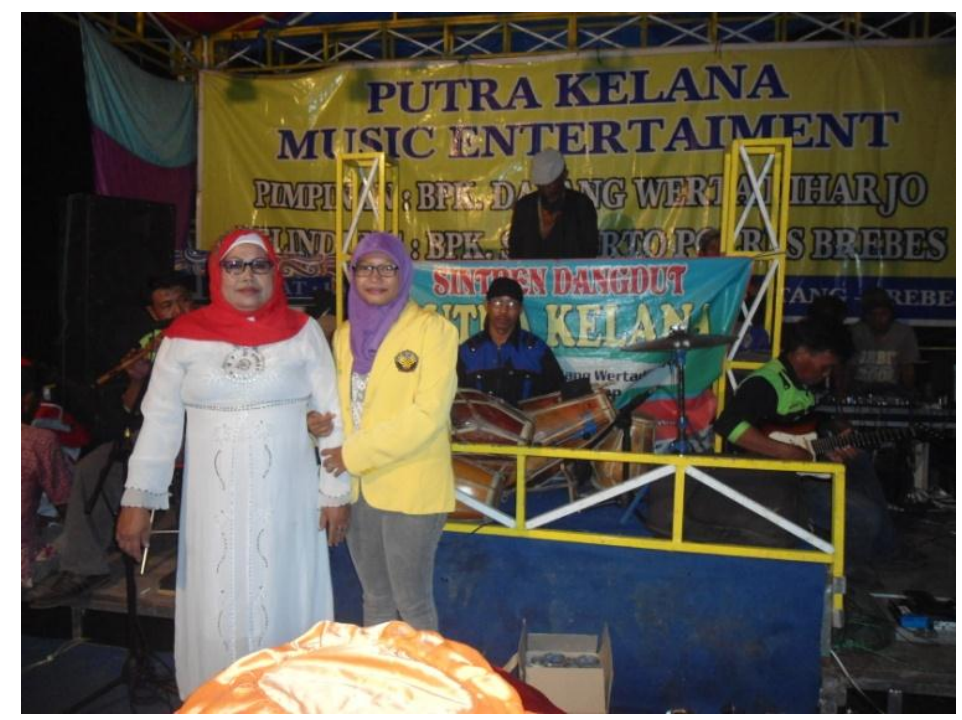

Foto 25

Malam pertunjukan Sintren Dangdut (dokumentasi: Rani, Brebes Maret 2016) 


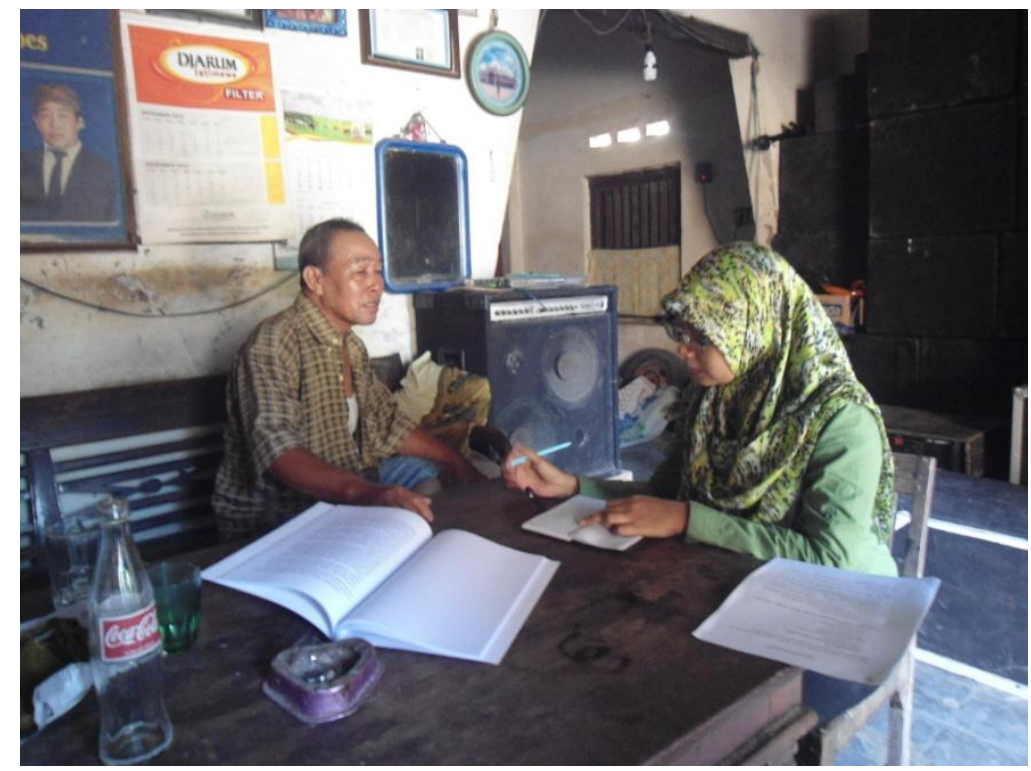

Foto 26

Wawancara dengan pimpinan Grup Putra Kelana (dokumentasi: Rista, Brebes April 2016)

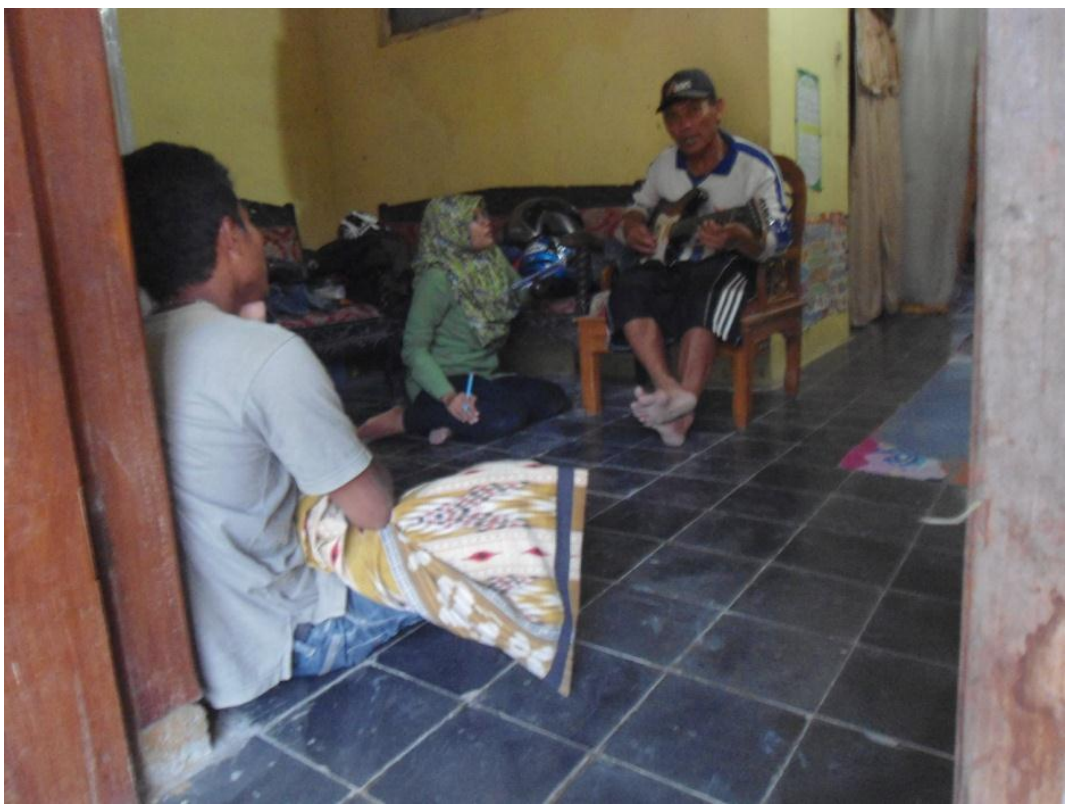

Foto 27

Wawancara dengan pemusik

(dokumentasi: Rista, Brebes April 2016) 
Lampiran 8

\section{SURAT KETERANGAN PENELITIAN}

Yang bertanda tangan di bawah ini:

Nama : Dalang Wertadiharjo

Alamat : Pasarbatang Brebes

Status : Pimpinan Grup Putra Kelana Pasarbatang Brebes

Dengan ini menerangkan bahwa mahasiswa berikut:

Nama : Amalia Mega Hardiyanti

NIM $: 2501412015$

Jurusan : Pendidikan Sendratasi (Seni Tari)

Fakultas : Bahasa dan Seni

Benar-benar telah melaksanakan penelitian untuk memperoleh data tentang

Bentuk Pertunjukan Kesenian Sintren Dangdut Pada Grup Putra Kelana di

Kelurahan Pasarbatang Kabupaten Brebes.

Brebes, April 2016

Yang menerangkan,

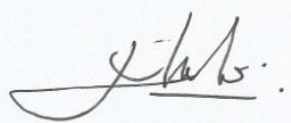

Dalang Wertadiharjo 
Lampiran 9

\section{TRANSKIP WAWANCARA}

\section{Wawancara 1}

Narasumber : Bapak Dalang Wertadiharjo (Pimpinan grup Putra Kelana)

Tempat : Kelurahan Pasarbatang Kabupaten Brebes

Waktu : April 2016

Keterangan $\quad: \mathrm{P}=$ Peneliti dan $\mathrm{D}=$ Narasumber

P : Bapak di Grup Putra Kelana sebagai apa ya?

D : Bapak sebagai Pimpinan nok

P : oh, Bapak memimpin Grup ini sudah dari tahun berapa?

D : Sudah dari tahun 1980-an, dulu sebelum saya Grup ini di pimpin oleh bapak saya, jadi pimpinan grup ini turun temurun keluarga.

P : Di grup ini ada kesenian apa aja ya pak? Apa Cuma sintren dangdut?

D : Tidak nok, di grup ini ada banyak kesenian seperti sintren dangdut, jaipong dangdut, kuda lumping, burok dangdut, organ tunggal. Tapi akhir-akhir ini yang sering di tanggap ya sintren dangdut.

P : Berarti kegiatan dalam grup ini tidak hanya untuk sintren dangdut ya pak?

D : Tidak nok, ada banyak kegiatan selain itu. Seniman juga punya kegiatan sendiri kalau tidak ada tanggapan, ada yang bertani, dagang dan sebagainya. Kaya bapak ya sehari-hari dagang nok.

P : Begitu ya pak, kalau Sintren dangdut sendiri masuk brebes itu sejarahnya bagaimana pak? 
D : Dulu itu belum dinamai sintren dangdut nok masih sintren biasa belum dimasuki dangdut, setelah sekitar tahun 2009 baru bapak campurkan pentas sintren dengan dangdut karena minat masyarakat yang lebih ke dangdutnya. Kalau hanya sintren saja jaman sekarang tidak laku.

$\mathrm{P}$ : Mengapa bapak tetap melestarikan kesenian sintren sedangkan masyarakat sudah jarang yang suka?

D : Ya bapak dari dulu memang keturunan dalang nok, kalau ibu keturunan sintren. Jadi bapak dan ibu ingin tetap ada kesenian sintren. Tetapi dengan minat masyarakat ke dangdut jadi bapak padukan sintren dengan dangdut. Alhamdulillah tanggapan tahun ini laris nok. Banyak hajatan banyak juga yang nanggap sintren dangdut.

$\mathrm{P}$ : Kalau masyarakat sekitar sini terganggu tidak pak dengan adanya grup bapak?

D : Masyarakat alhamdulillah mendukung nok, jadi bapak terus melestarikan kesenian ini. Sintren dangdut brebes beda dengan sintren pemalang atau pantura yang lain karena sudah dipadukan dengan dangdut. Tapi dangdut itu sebenarnya hanya selingan di pertengahan dan di akhir pertunjukan saja. Jadi ciri khas sintren tidak hilang, hanya saja di selingi dangdut.

$\mathrm{P}$ : Berarti bapak termasuk seniman yang berusaha mengupayakan pelestarian seni tradisi kesenian tradisional ya?

D : Bisa dibilang begitu nok. Heehehe

$\mathrm{P}:$ Oke pak terimakasih atas informasinya

D : Iya nok, kalau ada pertanyaan lagi datang aja tidak usah sungkan.

$\mathrm{P}$ : Iya pak 


\section{Wawancara 2}

Narasumber : Bapak Amad (Pemusik)

Tempat : Desa Sigambir Kabupaten Brebes

Waktu : April 2016

Keterangan $\quad: \mathrm{P}=$ Peneliti dan $\mathrm{D}=$ Narasumber

P : Selamat sore pak. Apa benar bapak Amad pemusik di grup Putra Kelana?

D : Iya nok, bapak salah satu pemusik

$\mathrm{P}$ : Jenis musik apa yang bapak mainkan?

D : Jenis musik gitar elektrik nok.

$\mathrm{P}$ : Oh berarti kesenian sintren dangdut brebes terutama pada grup putra kelana sudah tidak memakai gamelan lagi ya pak?

D : Iya nok, instrumen musik sudah modern. Sudah pakai keyboard, gitar elektrik, suling, tetapi masih memakai blampak atau kendang, terus gong, terus tutukan,terus kecrek. Alat musike gabungan dari modern dan sunda. Karena brebes itu langsung berbatasan dengan Jawa Barat Cirebon jadi musik sintren dangdut ya campuran.

$\mathrm{P}$ : Begitu ya pak, untuk alat musik utamanya itu dari kendhang apa gimana pak?

D : Bukan nok, melodi utama ya dari gitar elektrik. Kendhang hanya sebagai pengiring saja.

$\mathrm{P}$ : Kalau begitu saya boleh meminta notasi lagu sintren pak?

D : Boleh nok nanti saya ambil gitarnya dulu.

$\mathrm{P}:$ Terimakasih ya pak.

D : Iya sama-sama 


\section{Wawancara 3}

Narasumber : Ibu Musdah (Pawang Sintren Dangdut)

Tempat : Kelurahan Pasarbatang Kabupaten Brebes

Waktu : April 2016

Keterangan $\quad: \mathrm{P}=$ Peneliti dan $\mathrm{D}=$ Narasumber

$\mathrm{P}$ : Ibu sebagai pawang pada pentas kesenian sintren dangdut?

D : Iya nok ibu pawangnya. Bagaimana?

$\mathrm{P}:$ Persiapan apa saja sebelum pentas bu?

D : Sebelum pentas biasanya pawang ya menyiapkan perlengkapan sesaji dan perlengkapan sintren seperti baju sintren dan peralatan sintren diatas panggung.

$\mathrm{P}$ : Apa ada ritual khusus pawang sebelum pentas bu?

D : Ritual khusus tidak ada, paling biasanya biar acara lancar pawang itu puasa sehari sebelum pentas. Tapi kalau tidak puasa ya tidak apa-apa. Biasanya yang jadi pawang itu sudah keturunan nok, jadi gampang memanggil dewi-dewinya. Kalau bukan keturunan biasanya agak susah memanggil dewi-dewi agar masuk dalam diri sintren dangdut.

$\mathrm{P}$ : Begitu ya bu, apa setelah sintren dipadukan dengan dangdut ada perbedaan dari yang dahulu?

D : Perbedaan sih hanya pada selingan dangdut saja, dan pada saat selingan dangdut pertengahan pentas sintren ikut menari dengan biduan. Selebihnya masih sama dengan sintren yang dahulu. Dangdut itu hanya sebagai upaya pelestarian seni tradisi agar masyarakat minat dengan kesenian tradisional seperti sintren itu. Karena masyarakat sekarang sudah jarang yang menyukai kesenian tradisional. 


\section{Wawancara 4}

Narasumber : Mangesthi L. D. S (masyarakat)

Tempat : Kelurahan Pasarbatang Kabupaten Brebes

Waktu : April 2016

Keterangan $\quad: \mathrm{P}=$ Peneliti dan $\mathrm{D}=$ Narasumber

P : Apa anda mengetahui tentang kesenian sintren dangdut pada grup Putra Kelana?

D : Oh iya saya tahu, sintren yang di gabung dengan dangdutan itu.

$\mathrm{P}$ : Bagaimana pendapat anda tentang sintren dangdut?

D : Sintren dangdut itu masih kesenian tradisional hanya saja sudah agak modern dengan digabungkan dangdut. Alat musiknya juga sudah tidak menggunakan gamelan. Jadi sintren yang tadinya monoton dan membosankan, dengan adanya dangdut jadi berkembang kembali. Masyarakat seperti saya juga lebih tertarik dengan adanya dangdut. Jadi ya gag begitu-begitu aja.

$\mathrm{P}$ : Bagaimana kesan anda terhadap kesenian sintren dangdut?

D : Kesannya sangat baik ya dengan adanya dangdut. Jadi mungkin bisa jadi itu sebagai upaya pelestarian budaya di Indonesia.

$\mathrm{P}$ : Oh iya terimakasih atas waktunya.

D : sama-sama mbak. 
Lampiran 10

\section{LIRIK LAGU WARUNG POJOK}

Akeh wong pada kedanan masakan

Akeh wong pada kelingan pelayan

Ora klalen ning kesopanan ning sekabeh lelangganan

Yen tes balik jalan jalan mingguan

Mumpung bae tes gajian kaulan

Warung pojok go ampiran etung etung kekenalan

Tobal dendenge

Emi rebuse

Sega gorenge

Daginge gede gede

Aduh kopie

Tobat bukete

Aduh manise

Persis kaya pelayane

Pura pura mata mlirik ning duwur

Padahal ati tertarik lan ngawur

Nginum kopi mencak nyembur

Kesebab nyasar ning cungur 
LIRIK LAGU ADA RINDU

Ada rindu di malamku

Ada resah di tidurku

Ada tangis di hatiku

Ada hasrat yang menggebu

Ada engkau di hatiku

Berlari dalam malamku

Ada senyum di mataku

Yang menyiksa pandanganku

Reff

Ingin berjumpa denganmu

Walau sekedar di mimpiku

Walau sekedar di mimpiku

Sampai kapankah menunggu

Hari-hari indah denganmu

Hari-hari indah denganmu

Aku tak bisa, aku tak kuasa

Bila tak bertemu, bila ku tanpamu

(kembali ke reff)

Ada rindu di malamku

Ada resah di tidurku

Ada senyum di mataku

Yang menyiksa pandanganku 


\section{LIRIK LAGU OLEH-OLEH}

Berangkatlah sayang hati hati di jalan

Do'a kusertakan mohon kepada Tuhan

Semoga tiada arah melintang

Macam macam godaannya setan

Restu cintaku untukmu

Oh pujaan

Berangkatlah sayang hati hati di jalan

Aku Tidak minta oleh oleh

Emas permata dan juga uang

Tapi yang kuharap engkau pulang

Tetap membawa kesetiaan

Dirimu bagaikan layang layang

Kulepas tali benang ku genggam

Semakin melayang kau di awan

Semakin aku takut kehilangan

Aku Tidak minta oleh oleh

Emas permata dan juga uang

Tapi yang kuharap engkau pulang

Tetap membawa kesetiaan

Dirimu bagaikan layang layang

Kulepas tali benang ku genggam

Semakin melayang kau di awan

Semakin aku takut kehilangan

Berangkatlah sayang hati hati di jalan

Do'a kusertakan mohon kepada Tuhan 
Lampiran 11

\section{Biodata Peneliti}

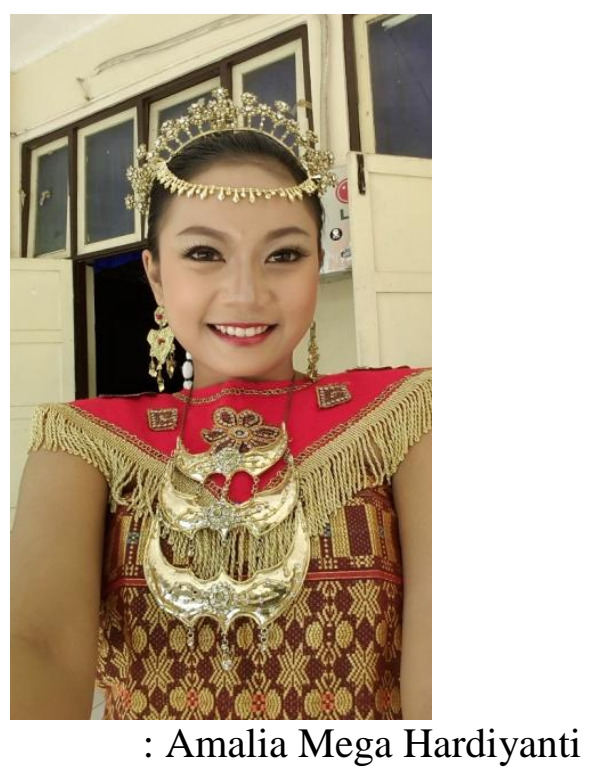

Tempat Tanggal Lahir : Tegal, 20 Desember 1993

Hobi : Menari dan Jalan-Jalan

Alamat

: Jln. Belitung no. 125 Rt.04 Rw.07

Limbangan Wetan Brebes 52212

Email

:amaliamegal@gmail.com

Orang tua Ayah $\quad$ : Abdul Haris (Alm)

Orang tua Ibu $\quad$ : Endang Supriyanti

Riwayat Pendidikan : SD Negeri 01 Brebes Lulus 2006

SMP Negeri 2 Brebes Lulus 2009

SMA Negeri 2 Brebes Lulus 2012 